University of Louisville

ThinkIR: The University of Louisville's Institutional Repository

Electronic Theses and Dissertations

$12-2006$

\title{
Men, cohesion, and battle : the Inniskilling Regiment at Waterloo.
}

Mark Richard Bois

University of Louisville

Follow this and additional works at: https://ir.library.louisville.edu/etd

\section{Recommended Citation}

Bois, Mark Richard, "Men, cohesion, and battle : the Inniskilling Regiment at Waterloo." (2006). Electronic Theses and Dissertations. Paper 123.

https://doi.org/10.18297/etd/123

This Master's Thesis is brought to you for free and open access by ThinkIR: The University of Louisville's Institutional Repository. It has been accepted for inclusion in Electronic Theses and Dissertations by an authorized administrator of ThinkIR: The University of Louisville's Institutional Repository. This title appears here courtesy of the author, who has retained all other copyrights. For more information, please contact thinkir@louisville.edu. 
MEN, COHESION, AND BATTLE:

THE INNISKILLING REGIMENT AT WATERLOO

\author{
By \\ Mark Richard Bois \\ B.A., University of Kansas, 1980
}

\begin{abstract}
A Thesis
Submitted to the Faculty of the

Graduate School of the University of Louisville

In Partial Fulfillment of the Requirements

For the Degree of
\end{abstract}

Master of Arts

Department of History

University of Louisville

Louisville, Kentucky

December 2006 
MEN, COHESION, AND BATTLE:

THE INNISKILLING REGIMENT AT WATERLOO

\section{By}

Mark Richard Bois

B.A., University of Kansas, 1980

A Thesis Approved on

December 8, 2006

By the following Thesis Committee:

Dr. Wayne E. Lee, History Department

Thesis Director

Dr. Karen Spierling, History Department

Dr. Karen Hadley, English Department 


\section{DEDICATION}

As always, for Charmin 


\section{ACKNOWLDEGEMENTS}

I would first like to thank my thesis advisor, Dr. Wayne Lee, for his generous support and unfailing scholarly expertise. I must also extend my sincere thanks to the other thesis readers, Dr. Karen Spierling of the History Department and Dr. Karen Hadley of the English Department for their professionalism and kindness. I owe special thanks to the staff at the British National Archives at Kew, and Major Jack Dunlop of the Inniskilling Regimental Museum at Enniskillen. My friends offered unfailing support, and I must single out Dr. Mark Wurster and Dr. Bob Ferlauto for their encouragement and assistance. But in the end I owe everything to my family: Jonathan, Kevin, Catherine, Genevieve, Patrick, and mo grah, mo mheile stor, Charmin. 


\title{
ABSTRACT \\ MEN, COHESION, AND BATTLE: \\ THE INNISKILLING REGIMENT AT WATERLOO
}

\author{
Mark Richard Bois
}

December 8, 2006

Advisor: Dr. Wayne E. Lee

This thesis is a social and military history of the First Battalion of the $27^{\text {th }}$ Foot, the Inniskilling Regiment, at the Battle of Waterloo. Crucial to success in battle is the cohesion of units and their ability to withstand punishment and keep fighting. This paper offers an examination of the constituent elements of unit cohesion as manifested in the demonstrable staying power of the Inniskillings. The Inniskillings' battlefield experience is a case study in cohesion: by understanding the devastating battlefield experience of the 
$1 / 27^{\text {th }}$, the only all-Irish infantry unit at Waterloo, it is then possible to examine the many elements of cohesion that allowed them to stand together.

The thesis opens with a brief summary of the historiography of military history in general, and the importance of the individual in the "new" military history. The introduction is followed by three sections: the battlefield experience, a social profile of the soldiers and officers, and an analysis of the myriad factors that shaped the men. The section on the battlefield experience offers as much detail as possible on what it was actually like for the men of the $1 / 27^{\text {th }}$ to serve in the Campaign of 1815 . How far did they have to march? What did they have to carry? What was the weather like? Where at Waterloo did they stand, and what was it like there?

The second section of the paper, dealing with the background of the men of the $1 / 27^{\text {th }}$, opens with a brief history of Ireland, and the issues that formed Irish society and culture. An assortment of primary sources and Irish census data are then used to paint a picture of just who these men were.

The final section of the thesis borrows John Lynn's model developed in his landmark Bayonets of the Republic to examine the motivational and military systems in place in the British army of the Napoleonic Wars. This model considers such motivational factors as interest and morale, and military factors such as organization and experience. 
TABLE OF CONTENTS

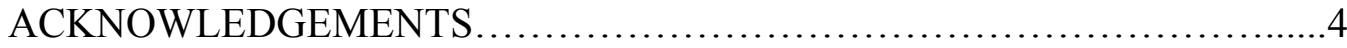

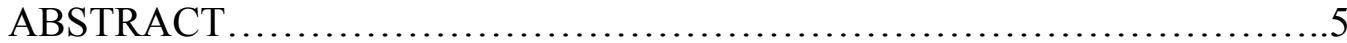

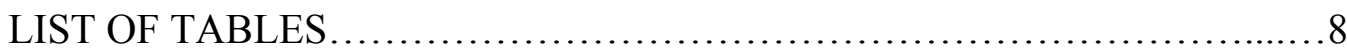

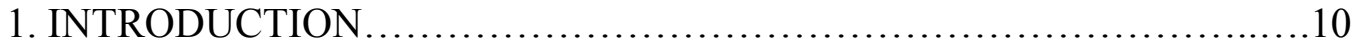

2. THE BATTLEFIELD EXPERIENCE......................................18

3. THE MEN

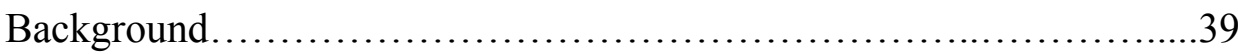

Societal Data..........................................................

4. MILITARY MODEL

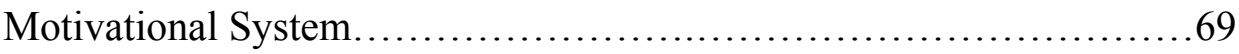

Military System..................................................... 110

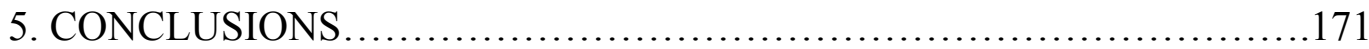

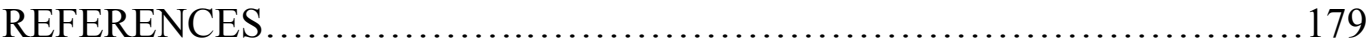




\section{LIST OF TABLES}

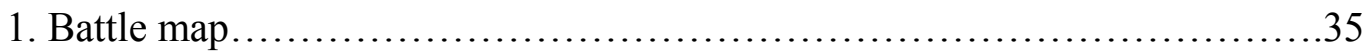

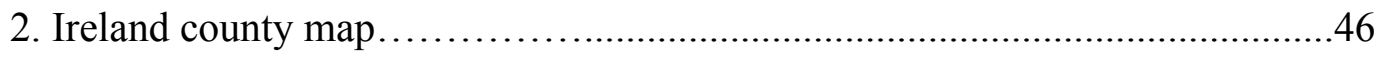

3. Where Born, by Percent................................................. 47

4. Full Battalion, Place of Birth, Extrapolated................................48

5. Full Battalion, County of Birth, Extrapolated..............................48

6. Irish Religions by Percent...............................................52

7. Religious Affiliations of Ireland, by County, by Province.....................53

8. Religious Affiliations of $1 / 27^{\text {th }}$, in Percent, by sect..........................54

9. Religious Affiliations of $1 / 27^{\text {th }}$, in Percent, Protestant/Catholic................54

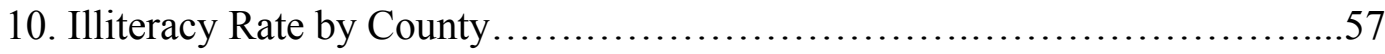

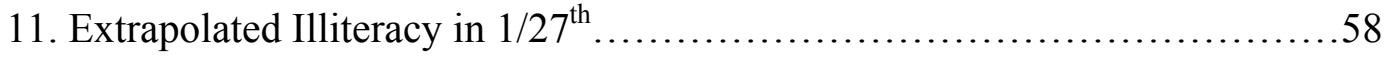

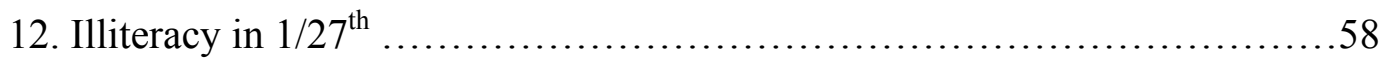

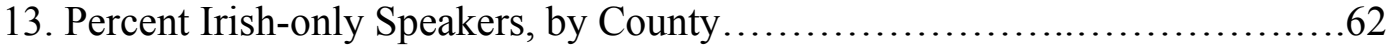

14. Extrapolated Irish-only Speakers.....................................62

15. Numbers of Homes, by Class, by County …............................64

16. Fourth Class Housing, by County ….................................65 
17. Fourth Class Housing, by County, in Percent ............................65

18. Years of Experience in rank, by rank, by Regiment........................ 128

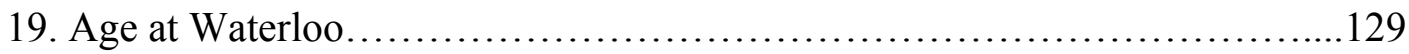

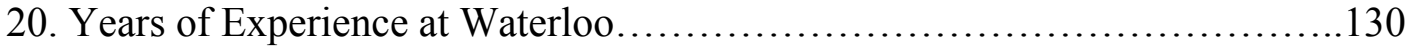

21. Age at Enlistment.................................................. 135

22. Where Attested, in Percent...........................................137

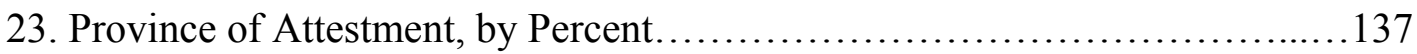

24. Attestment by County by Percent.................................... 137

25. Skilled vs. Unskilled laborers, in Percent.................................. 139

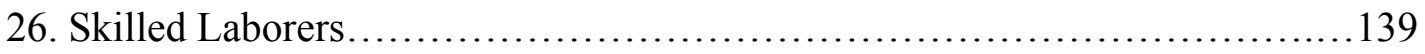

27. Unskilled Laborers...................................................... 140

28. Formations at Waterloo............................................. 155

29. Career Paths of the Waterloo Officers, $1 / 27^{\text {th }}$ Foot........................... 165 


\section{INTRODUCTION}

Patrick Corbett served in the British army as a private in the First Battalion of the

$27^{\text {th }}$ Regiment of Foot, the Inniskilling Regiment. Corbett was killed during the afternoon of June $18^{\text {th }}, 1815$, near the Charleroi road during the Battle of Waterloo. His name will not be found in any history book nor do surviving military records tell us much about Corbett. He was born in the County Clare, and in civilian life he worked as a stone mason. There is no record of how he died in the hell of noise, confusion, and fear that engulfed the ranks as the Inniskillings were raked by musketry and cannon fire. The details of his service and death are lost and his personal sacrifice is forgotten.

Corbett is alone neither in his anonymity nor in his sacrifice. He served in the first company of the $1 / 27$ th, and of the nearly one hundred men of that company eleven others died at Waterloo. More than forty more men of the first company were wounded, and one of those wounded men, Thomas Hoyle, a former weaver from the County Armagh, lingered for nearly a month before dying. Hoyle's suffering can only be imagined, yet his anonymity is as complete as Patrick Corbett's and every other man of the regiment. 
The goal of this thesis is to construct a thorough study of the Inniskillings at Waterloo. The study will follow two paths: an experiential history of the Inniskillings at Waterloo, and a social history of the men who comprised the first battalion. Further, this paper will investigate the nature of unit cohesion that bound together the men of the Inniskilling Regiment in the face of a battlefield experience among the most severe suffered by any unit at Waterloo. Of the seven hundred men of the battalion, more than four hundred fifty were killed or wounded in that single long day, yet the battalion did not break. Both historians and contemporary diarists note the Inniskillings' loss and perseverance as exceptional. The elements of cohesion that bound those men together are critical to understanding the men of the regiment, and can be applied to many other military formations throughout military history.

Understanding who the Inniskillings were and what they experienced can provide better understanding of the Battle of Waterloo, and can give further insights into the greater issues of military history. Patrick Corbett, Thomas Hoyle, and their fellow soldiers need to be given a face, and a voice.

This thesis is organized into three sections. The first deals with the actual experience of the Inniskillings in 1815. How far did they march? How tired were they? What were the details of their battlefield experience? The second section discusses the sociological information available regarding the men of the $1 / 27^{\text {th }}$. Numerous subjects such as their birth places, ages, religion, and experience levels are explained, and a brief discussion of Irish history and culture places those details in context. Lastly, the myriad details of the Inniskillings' military life are presented. The details are organized, and 
their relevance explained, using the framework developed by John Lynn in his landmark work The Bayonets of the Republic. ${ }^{2}$ While Lynn used his model to examine the French Armée du Nord from 1791-1794, the same framework can be successfully applied to the Inniskillings. The model transfers with surprising ease to a British unit of only seven hundred men, as they were of the same time period as Lynn's Frenchmen. Lynn's model features sections on such diverse topics as weapons, tactics, medical care, and recruitment. Other topics such as soldiers' families are added to the present study due to their importance and relevance in this study of a battalion-size unit.

The sources consulted for this thesis consist as much as possible of primary sources, and where primary sources are missing the best of contemporary scholarship is utilized. The primary sources are of four varieties. The first consists of memoirs, letters, and diaries from 1815; unfortunately such sources from the men of the Inniskillings are rare. There are no known memoirs left by any enlisted men of the $1 / 27^{\text {th }}$, and the officers' memoirs provide a sadly incomplete picture. Those gaps, however, can be filled satisfactorily by the memoirs of other British soldiers who had similar experiences at Waterloo.

The second type of primary source materials are the numerous records maintained by the $1 / 27$ th in 1815 . Records such as pay rosters, casualty returns, and recruiting rosters are available in the British National Archives, but legibility, missing entries, and conflicting data render their use a challenge. Nevertheless, these sources are in many ways the heart of this thesis: the names and backgrounds of the Inniskillings reside only here. The records have to been compared in great detail to finally yield the most accurate database possible.

\footnotetext{
${ }^{2}$ John A. Lynn, The Bayonets of the Republic (Boulder, CO.: Westview Press, 1984).
} 
Period military manuals and private military publications comprise the third type of primary source. Official army regulations were remarkably detailed in how infantry soldiers were to be trained and maneuvered, but they were limited in scope. ${ }^{3}$ Privately published works, often written by serving officers, served a valuable function in introducing innovation to the army. ${ }^{4}$ The modern scholar must, however be careful not to mistake the musings of military enthusiasts for official army policy. ${ }^{5}$ A useful measure of tacit government approval of private works was the permission granted by the King or the Duke of York to have works dedicated to them. ${ }^{6}$ One such publication dedicated to the Duke of York was The Regimental Companion, an officer's guide of exceptional breath and depth., and was thus of great use to this study.

Lastly, data from the Irish Censuses of 1831, 1841, and 1861 are available in an on-line database provided by the University of Essex. ${ }^{7}$ Again, the volume and raw nature of the data makes its use a challenge, but in the end has it proved a very useful primary source measure of Irish society in the early $19^{\text {th }}$ century. For example, literacy rates for military-age Irish men of the $18^{\text {th }}$ century, by county, is a very valuable tool.

Since 1815 hundreds of secondary works of wildly divergent quality have been published about Waterloo. Most are traditional military histories that concentrate on strategy, tactics, and the command qualities of Napoleon and Wellington. The first great history of the battle was Captain William Siborne's History of the War in France and

\footnotetext{
${ }^{3}$ See Great Britain, Army, Infantry, Rules and Regulations for the formations, field-exercise, and movements, of His Majesty's forces (London: War Office, 1792).

${ }^{4}$ J. A. Houlding, Fit for Service: The Training of the British Army, 1715-1795 (Oxford: Clarendon Press, 1981), 166-172.

${ }^{5}$ For example, see Henry Dalrymple, Tacticks (Dublin: George Bonham, 1782).

${ }^{6}$ J. A. Houlding, Fit for Service, 169.

${ }^{7}$ Clarkson, L.A. et al., Database of Irish Historical Statistics [computer file]. Colchester, Essex: UK Data Archive [distributor], November 1997. http://www.data-archive.ac.uk/
} 
Belgium, published in 1848. At first glance even the most critical reader would applaud Siborne's scholarship, as he based his history on surveys that he sent to hundreds of men who had participated in the battle. But Siborne restricted his research to British officers. No French, Prussian, Dutch, or Belgian officer had input into Siborne's history, and no common soldier was questioned regarding his view of the battle. The Siborne history, naturally, hailed the British, insulted their allies, and praised the French only in order to further glorify the British officers who conquered them. The common soldier was reduced to stereotypes: brave but nervous Frenchmen, brave but clumsy Prussians, cowardly Belgians, inexperienced Dutchmen, and brave, stoic, patriotic Britons. But most of all, the common soldier was anonymous. Of the two hundred thousand enlisted men in the warring armies Siborne refers to only a handful by name. ${ }^{8}$

The anonymity of the common soldier was a hallmark of histories of the Battle of Waterloo well into the twentieth century. But by the 1980's a new form of military history was taking root that began to explore the role of men in combat, spurred on and exemplified by John Keegan's classic The Face of Battle. ${ }^{9}$ While traditional histories could still be relied upon to discuss the strategies, tactics, and commanders of the Campaign of 1815 , the "new" military history began to focus on the human element in war. The new military history represented a shift in emphasis "from narrower focus on tactics and commanders to a broader and often interdisciplinary focus on the interaction of war with society, technology, economics, politics, and culture." 10

\footnotetext{
${ }^{8}$ Captain William Siborne, History of the War in France and Belgium in 1815 (London: T. and W. Boone, 1848).

${ }^{9}$ John Keegan, The Illustrated Face of Battle (New York, Viking Penguin Inc., 1989).

${ }^{10}$ John Whiteclay Chambers, "Conference Review Essay: The New Military History: Myth and Reality", The Journal of Military History, Vol. 55, No. 3 (Jul., 1991), 398.
} 
The new military history has evolved from its infancy as it grew and branched into new styles of scholarship. One branch has utilized many of the tools and terminology of sociology in examining armies. Works such as The British Army in the West Indies: Society and the Military in the Revolutionary Age by Roger Norman Buckley and Women of the Regiment: Marriage and the Victorian Army by Myna Trustram are two such works, displaying a great deal of primary research and excellent scholarship. ${ }^{11}$ But some military historians argue that these works stray too far from what armies do, as in the last resort armies are created to fight. ${ }^{12}$

Some later secondary works have attempted to correct the previous pro-British bias. The German perspective on the Campaign of 1815 is the focus of recent works by Peter Hofschröer, while Waterloo, edited by Lord Arthur Chalfont, consists of contributions by three authors: one British, one French, and one German. ${ }^{13}$ A third work, The Hundred Days by Anthony Brett-James, features officers and enlisted men from both the Allied and French armies, but relies so heavily on extensive quotes that Brett-James borders on becoming what John Keegan calls the "historian as clerk-typist."14 Despite the incalculable value of personal accounts, the duty of the historian is to interpret such information, not merely to present it.

Another branch of the new military history deals with the psychology of men at war. The central theses of many of these works focus on the willingness of humans to

\footnotetext{
${ }^{11}$ Roger Norman Buckley, The British Army in the West Indies: Society and the Military in the Revolutionary Age (Gainesville: University Press of Florida, 1998) and Myna Trustram, Women of the Regiment: Marriage and the Victorian Army (Cambridge: Cambridge University Press, 1984).

${ }^{12}$ John Lynn, "The Embattled Future of Academic Military History", The Journal of Academic Military History, 783.

${ }^{13}$ Peter Hofschröer, 1815: The Waterloo Campaign, (London: Greenhill Books, 1999) and Lord Arthur Chalfont, ed., Waterloo: Battle of Three Armies (New York: Alfred A. Knopf, 1979).

${ }^{14}$ Anthony Brett-James, The Hundred Days (New York: St. Martin's Press, 1964), John Keegan, The Face of Battle, 32.
} 
kill. One of the earliest studies is S. L. A. Marshall's 1947 Men Against Fire, which proposed that American soldiers in combat in World War II were inherently reluctant to kill their enemies. ${ }^{15}$ While Marshall's scholarship has been questioned, numerous important works on the study of killing in battle followed, including, in the 1980's, Blood Rites by Barbara Ehrenreich and On Killing by Lt. Colonel Dave Grossman. ${ }^{16}$ While both Ehrenreich and Grossman raise intriguing questions, their conclusions are far from proven. At one point Grossman argues that soldiers with muzzle-loading weapons deliberately missed their opponents, and that "when faced with a living, breathing opponent instead of a target, a significant majority of the soldiers revert to a posturing mode in which they fire over their enemy's heads". ${ }^{17}$ Such arguments are undermined by battlefield experiences such as that suffered by the Inniskillings at Waterloo. The Inniskillings' casualty returns bear mute testimony to the deliberation of French fire; all accounts cite the very accurate musketry from the knoll opposite La Haye Sainte as a cause of many of the Inniskilling casualties.

But the key element of the experience of the Inniskillings at Waterloo was not killing: it was dying. While the Inniskillings certainly did kill and injure some of their French opponents, the Inniskillings lost so many men, so quickly, that any study of that battalion must primarily focus on the motivational factors that instilled the determination to suffer great loss yet maintain their discipline. This determination to suffer without fleeing is a crucial aspect of many current studies of men in combat, many of which will be cited in the pages of this thesis. There were many motivational factors and elements

\footnotetext{
${ }^{15}$ S. L. A. Marshall, Men Against Fire (Norman: University of Oklahoma Press, 1947).

${ }^{16}$ Barbara Ehrenreich, Blood Rites (New York: Metropolitan Books, 1997) and Lt. Colonel Dave Grossman, On Killing (Boston: Back Bay Books, 1995).

${ }^{17}$ Dave Grossman, On Killing, 11.
} 
of group cohesion that served to bind the men of the $1 / 27^{\text {th }}$ together. That combination of motivation and cohesion kept the Inniskillings in place, to be killed and wounded in astounding numbers. 


\section{THE BATTLEFIELD EXPERIENCE}

The course of the battle at Waterloo in 1815 has been well documented in countless histories, but a brief outline is necessary here to provide a context for the experience of the Inniskillings. That outline will be followed by a study of the specific actions of the Inniskillings during the campaign.

Severely undermined by the disaster in Russia in 1812, Emperor Napoleon I proved unable to prevent the Allied invasion of France in 1814, and he abdicated the throne in April of that year. The restoration of the Bourbon King Louis XVIII and Napoleon's subsequent exile to Elba seemed to have brought the long series of Revolutionary and Napoleonic wars to an end. But the return of Bourbon rule in France proved to be very unpopular, promptng the restive Napoleon to risk a return to France and another bid for the throne. The gambit proved wildly successful, and despite Napoleon's assertions that his international intentions were entirely benevolent, the Allied nations meeting at the Congress of Vienna declared him an outlaw. The British representative to the Congress, Sir Arthur Wellesley, the Duke of Wellington, was named 
the overall commander of the Allied forces as all the great nations of Europe began to reassemble their armies to force Napoleon out of France once again.

Rather than await an invasion of France by the Allied armies, Napoleon opted for a preemptive strike against the Prussian and Anglo-Allied armies assembling on France's northern borders. ${ }^{21}$ Napoleon's Armée du Nord totaled some 122,000 men, most of whom were veteran soldiers, and who were led by some of the finest officers of the era. The French were opposed by Feldmarshall Wilhelm Blücher's Prussian army of 126,000 men, and 112,000 men of the Anglo-Allied army under Sir Arthur Wellesley, the Duke of Wellington. The Prussian army was a mixture of veterans and raw recruits, some of whom were very unhappy about serving under Prussian command. ${ }^{22}$ Wellington's army was only one third British, the majority of whom were veteran troops, while the balance of the army was composed of Dutch, Belgian, and German forces of varying levels of experience and determination. ${ }^{23}$

The campaign of 1815 began on June 15th as the Armée du Nord crossed the frontier into Belgium. Napoleon's attack took both Wellington and Blucher by surprise, and the French were initially confronted only by scattered elements of the Allied forces as both Wellington and Blucher scrambled to assemble their armies. On June 16th Wellington assembled a portion of his troops at Quatre Bras and managed to fight a French corps to a draw. On the same day the Prussians massed three of their four corps to meet the French at Ligny but were defeated after a full day of bitter fighting.

\footnotetext{
${ }^{21}$ This summary is drawn from a number of works, the best being David Chandler, Campaigns of Napoleon (New York: MacMillan Publishing, 1966),1007-1095, Anthony Brett-James, The Hundred Days, Keegan, The Face of Battle, and Hofschröer, 1815: The Waterloo Campaign.

${ }^{22}$ Peter Hofschröer, 1815: The Waterloo Campaign, 50-55.

${ }^{23}$ Scott Bowden, Armies at Waterloo (Arlington, TX.: Empire Press, 1983), 319.
} 
On June 17th both the Prussian and Anglo-Allied armies fell back, pursued by the French. Wellington gathered the remainder of his army and made a stand at Waterloo, while the Prussians split their army. A Prussian rear guard fought the French at Wavre while the majority of Blucher's army marched to aid the Anglo-Allies at Waterloo.

The Battle of Waterloo took place on Sunday, June 18th. Heavy rain the night of the $17^{\text {th }}$ soaked the ground, and the movements of thousands of men, horses, and wheeled vehicles made the fields a quagmire. The mud delayed the start of the battle, as the last of the French guns and men were slow in getting into position.

Historians usually divide the battle into five phases: the attack on Hougomont, D'Erlon's infantry attack, the French cavalry attacks, the fall of La Haye Sainte, and the attack of the French Guard. ${ }^{24}$ Of course, the average soldier certainly had no sense of such a sequential progression to the day. Many participants in the battle echoed the opinion of one British officer who stated that smoke and confusion obviated "all possibility of their giving any correct account of the battles in which they may be engaged." 25 Battles are essentially an exercise in organized confusion, so to give any semblance of descriptive order to such a confused event requires the imposition of broadstroke frames of reference.

The first of the five phases involved an attack on the Chateau of Hougomont by a French corps under the command of Napoleon's brother, Jerôme. What Napoleon intended as a diversionary attack eventually escalated into a day-long series of attacks, as

\footnotetext{
${ }^{24}$ For example, see Keegan, The Face of Battle, 109-110, and Chandler, Campaigns of Napoleon, 10721089.

${ }^{25}$ Captain John Brown, $1 / 4^{\text {th }}$ Foot, in Captain William Siborne, Waterloo Letters (London: Greenhill Books, 1993) first published as Waterloo Letters (London: Cassell, 1891), 394.
} 
Jerôme tied up an entire corps of French troops against a comparatively small AngloAllied force.

The second phase of the battle took place on the left side of the Allied line, as the Comte D'Erlon led his corps forward. The attack opened with a massive artillery bombardment that mauled a Dutch-Belgian brigade, but the infantry assault was repulsed by a stout defense by the British infantry and a timely charge by the British heavy cavalry. One of the regiments that participated in that charge was the only Irish cavalry regiment at Waterloo: the $6^{\text {th }}$ Dragoon Regiment, the Inniskilling Dragoons.

The charge of the French heavy cavalry constituted the third phase of the battle. Marshal Michel Ney led a series of charges by twelve thousand heavy horsemen, many of whom were armored cuirassiers. The charges were ill-conceived, as the attack was on a narrow front against infantry that was still steady. The French cavalry suffered great loss, and while they put considerable pressure on the Allied army they were unable to break it.

For most of the day the French had launched a series of attacks against the farm of La Haye Sainte, and the final success of those attacks is deemed the fourth phase of the battle. La Haye Sainte was a key position in the center of the Allied line which was held by a battalion of the King's German Legion. The position fell only after the garrison ran out of ammunition, and its occupation by the French posed a serious threat to the Allied center.

The final phase of the Battle of Waterloo was the advance of the French Imperial Guard. As the Prussians under Blucher began to fall on the French right, Napoleon gambled that the commitment of his fresh Guard infantry would finally push the AngloAllies into retreat. He was mistaken; as the Guard advanced in the narrow gap between 
La Haye Sainte and Hougomont a final stand by Wellington's troops sent the French reeling.

A general advance by both the Prussian and Anglo-Allied armies turned the retreat of the French Guard into a rout of the entire army. The exhausted French troops broke and ran; the equally exhausted Anglo-Allies left most of the pursuit to the Prussians. The great battle was over; thousands of dead and wounded men and horses covered the ground. Napoleon could not recover from the loss, and he was forced to abdicate once again. His exile to St. Helena in the lonely South Atlantic was final, and he died there in 1821.

The Waterloo Campaign began for the First Battalion of the Inniskilling Regiment when they were stationed in Bermuda in April of 1815. The Inniskillings were in Bermuda following service against the Americans during the War of 1812. The Inniskillings' stay in Bermuda was brief, as the British government quickly recalled their widely scattered army in response to Napoleon's return to France. The battalion quickly shipped out, although heavy storms in the mid-Atlantic scattered the convoy of troop ships. The ship containing the battalion staff and three of the battalion's ten companies was damaged in the storms and was forced to sail for the Bahamas. The other seven companies arrived at Portsmouth on May $9^{\text {th }}$, though after enduring a month of Atlantic storms in cramped conditions with poor food, many of the men were unfit for service. It was decided that the second battalion of the $27^{\text {th }}$ would provide men to reinforce the first battalion. The second battalion, which had seen extensive service in the peninsular War, was stationed in Britain to rest, recruit, and train new men. Two hundred and eighty men 
were quickly drafted from the second battalion into the first battalion to fill out the ranks, and within a week the first battalion sailed again, this time for Ostend, Belgium. ${ }^{26}$

The Inniskillings arrived on May $24^{\text {th }}, 1815$, and were billeted in the city of Ghent. The battalion officers used the time in Ghent to organize, as the new men who had been drafted from the second battalion had to be assigned and integrated into their companies. The absence of the battalion staff and three of their companies put the $1 / 27^{\text {th }}$ in a unique situation, and the battalion had to operate with the resources at hand. The commanding officer was part of the missing contingent, so the senior captain, John Hare, took command. Other members of the battalion staff were missing as well, including the Sergeant Major, the Paymaster's clerk, and the Armourer. ${ }^{27}$ The battalion would have missed the leadership of the senior non-commissioned officer and discipline may have suffered as a result. The state of the surviving pay rosters shows the disorder caused by the absence of the Paymaster's clerk, and with so many men being exchanged with the second battalion the records were in further disarray. Lastly, with the battalion Armourer still at sea, malfunctioning weapons would have had to be taken to other battalions, or to Belgian gunsmiths.

The Inniskillings were part of the $10^{\text {th }}$ British Brigade under the command of Major General Sir John Lambert. The $1 / 27^{\text {th }}$ was brigaded with the $1 / 4^{\text {th }}$ and $1 / 40^{\text {th }}$, both veteran units from service in the Peninsula. All three regiments had distinctive nicknames. The $27^{\text {th }}$ was known as the "Skins", a corruption of Inniskilling. The $4^{\text {th }}$ was

\footnotetext{
${ }^{26}$ Lieutenant Charles Crowe, $1 / 27^{\text {th }}$, Memoirs, (unpublished manuscript, Inniskilling Regimental Museum, Enniskillen, Northern Ireland).

${ }^{27}$ United Kingdom War Office, $1 / 27^{\text {th }}$ Regimental rosters, $1815-1816$. WO $12 / 4344$.
} 
known as the "Lions" due to the emblem on their regimental badge, while the $40^{\text {th }}$ was called the "Exellers" because of the "XL" on the regimental badge. ${ }^{28}$

The $10^{\text {th }}$ British Brigade was part of the $6^{\text {th }}$ Infantry Division, commanded by Lieutenant General Sir Lowery Cole. The $6^{\text {th }}$ Division consisted of the 10th British Brigade, the $4^{\text {th }}$ Hanoverian Brigade, and one battery of British Royal Artillery. ${ }^{29}$ The Royal Artillery was a well-trained veteran service, but the $4^{\text {th }}$ Hanoverian Brigade consisted of four Landwehr battalions: raw troops with little training and poor equipment who could not be expected to bear much in battle. ${ }^{30}$ The Hanoverians were based in Brussels, and the scattered elements of the division would not be united until the morning of the 18th, at Waterloo.

The Inniskillings' respite in Ghent proved short-lived. Lieutenant Drewe of the Inniskillings wrote that "at a late hour on the night of the 15 th June we received a sudden route." Drewe did not describe the process of gathering the battalion, but ideally the men would be organized as efficiently as were those of the $1 / 92^{\text {nd }}$ Foot, the Gordon Highlanders, in Brussels. A sergeant of the Gordons wrote that upon receiving the orders to march drums and bugles were sounded, and

upon hearing this, sergeants and corporals ran to the quarters of their respective parties to turn them out. I went to the quarter-master for bread and four days' allowance was given out of the store, which was soon distributed among the men, every one getting his share and speedily falling into rank. So regularly and orderly was the affair gone about, that we were ready to march in half an hour after the first sound of the bugle. ${ }^{31}$

\footnotetext{
${ }^{28}$ Tim Carew, How the Regiments got their Nicknames (London: Leo Cooper, 1974), 8.

${ }^{29}$ Scott Bowden, Armies, 253-254.

${ }^{30}$ Peter Hofschröer \& Bryan Fosten, The Hanoverian Army of the Napoleonic Wars (London: Osprey, 1989), 38-41.

${ }^{31}$ Sergeant D. Robertson, 1/92 nd "What the Gordons did at Waterloo," in MacKenzie MacBride, ed., With Napoleon at Waterloo (Philadelphia: J.B. Lippincott Company, 1911), 152-153.
} 
The Inniskillings could not simply draw their rations and march out; the march of the three battalions of the brigade would have to be coordinated, and in turn coordinated with the artillery. It doubtless took a considerable time to get the men out of Ghent.

While there are no extant weather records from 1815 per se, an accurate record of the predominant weather conditions faced by the armies leading up to and during the battle can be gleaned from some of the more detailed memoirs. The night of June $15^{\text {th }}$ was clear, while on the 16 th "the day was oppressively warm and the road very dusty. ${ }^{32}$ During the $17^{\text {th }}$ the weather grew hot once again, and violent thunderstorms erupted during the afternoon. ${ }^{33}$ The night of the $17^{\text {th }}$ soaked the armies, as "the rain continued to fall in torrents until a little before 8:00 am when the weather began to clear up."34

On the $18^{\text {th }}$, the day of the battle, the wet men were chilled by the cool dawn air. The Highland regiments wore the kilt, and one of their sergeants wrote that "I never felt colder in my life; every one of us was shaking like an aspen leaf." ${ }^{35}$ The day warmed quickly, and throughout the battle the sky was mostly cloudy, the air hot and still.

Another factor that needs to be considered is illumination. Summer days in northern Europe are very long, thus giving armies extensive opportunity to operate. While the nights are comparatively short, the phases of the moon as well as the times of moonrise and moonset are important in considering any night marches. The times of sunrise and sunset, moonrise and moonset, and the phases of the moon can all be reviewed for their impact during the climatic days of June $1815 .^{36}$

\footnotetext{
${ }^{32}$ ibid., 154.

${ }^{33}$ Captain Cavalié Mercer, Journal of the Waterloo Campaign (New York: Da Capo Press, 1995), 145-151.

${ }^{34}$ Ensign Thomas Mountseven, $1 / 28^{\text {th }}$, in Gareth Glover, Letters from the Battle of Waterloo (London: Greenhill Books, 2004), 269.

${ }^{35}$ Sgt. D. Robertson, "What the Gordons did at Waterloo," in With Napoleon at Waterloo, 159.

${ }^{36} \mathrm{http}: / /$ aa.usno.navy.mil/data/docs/RS_OneDay.html
} 
If General Lambert received Wellington's orders at 2200 on the 15th, Captain Hare and the Inniskillings may have received their orders at $2300 .{ }^{37}$ The night of the $15^{\text {th }}$ had reasonable moonlight, and memoirists cite the weather as fine, so the troops had sufficient light to gather in the dark streets of Ghent. The moon set at 0207 on the morning of the $16^{\text {th }}$, so it is doubtful that the troops actually marched before sunrise at 0428.

Primary sources differ as to the route taken by the Inniskillings to Waterloo, but memoirs from the $1 / 40^{\text {th }}$ confirms that the $10^{\text {th }}$ British Brigade left Ghent very early on the morning of the $16^{\text {th }} .{ }^{38}$ The brigade marched thirty miles on the $16^{\text {th }}$, and another twenty-one on the $17^{\text {th }}$. The distances covered by the Inniskillings on two days of marching do not seem excessive in this age of automobiles, but to cover those fifty-one miles in two days on foot is no mean feat. Further, while many of the roads in 1815 Belgium were paved with cobblestones, the road was typically reserved for artillery and wheeled transport. The infantry had to march along the edges of the road. ${ }^{39}$

The fact that the Inniskillings marched as part of a much larger body of men also has to be considered. Whereas an individual can march at his own pace, as part of a divisional movement of 5,000 men and 8 guns, the Inniskillings would have spent a great deal of time standing in ranks waiting for other units to pass, or been urged to hurry to close gaps in the march column. The traffic congestion would have gotten worse as the Inniskillings got closer to Waterloo. One soldier who had been in the rear of the army reported to the Horse Artillery's Captain Mercer "that he had been much impeded by the

\footnotetext{
${ }^{37}$ For clarity's sake military time will be used in this study.

${ }^{38}$ Sergeant William Lawrence, The Autobiography of Sergeant William Lawrence (London: Sampson, Low, Marston, Saerle \& Rivington, 1886), 88.
} 
confusion on the road, which was everywhere crowded with wagons, etc. Many he had seen overturned, and many plundered, or being plundered." ${ }^{40}$ After a long, wet march the Inniskillings were just a few miles from Waterloo at midnight on the $17^{\text {th }}$. They were not allowed to rest, as for the remainder of that night they "were occupied some time in clearing the road of provision carts containing bread, forage, and spirits that had been left on the road by the peasantry taking their animals from the carts, and concealing themselves in the woods."41

There is no direct evidence, but it is likely that the Inniskillings took advantage of the confusion on the road to help themselves to food and, more importantly, alcohol. As can be seen in the timeline, at the time that the Inniskillings were clearing the road between Waterloo and Brussels it was raining, and there was no moon. The men were working in scattered parties to clear the road, and the combination of darkness, rain, and removal from their officers would have given the Inniskillings ample opportunity to break into the numerous rum and gin casks.

Alcohol was a staple of British army rations, and drunkenness was a recurrent issue in the army. The same soldier that reported to Mercer regarding the congestion in the rear also came across some casks of rum, and

having broached one of these - he and his drivers - every one filled his canteen - a most considerate act, and one for which the whole troop was most sincerely thankful. Nor must I omit to remark that, amidst such temptations, his men had behaved with the most perfect regularity, and returned to us quite sober! (original italics and exclamation mark) ${ }^{42}$

\footnotetext{
${ }^{39}$ Gunther Rothenberg, The Art of Warfare in the Age of Napoleon (Bloomington: University of Indiana Press, 1978), 139.

${ }^{40}$ Cavalié Mercer, Journal, 159.

${ }^{41}$ Lt. Edward Drewe, $1 / 27^{\text {th }}$, in Siborne, Letters, 395.

${ }^{42}$ Cavalié Mercer, Journal, 159.
} 
If Mercer was amazed at his men's restraint, it is likely that some of the Inniskillings, faced by the same temptation, fell. Instead of a few canteens of rum shared amongst an artillery battery, there may have been hundreds of canteens full of rum in the ranks of the battalion.

Another piece of evidence points to the possibility of some of the Inniskillings being affected by alcohol. In the section of this thesis regarding discipline, it is noted that four sergeants and twelve corporals were demoted to private after Waterloo. Many of the NCOs may have taken part in the drinking, or failed to prevent their men from doing so.

The Inniskillings, exhausted and with canteens full of rum, reached the village of Waterloo at about 0600, and were directed to the left of the Allied line. But those orders were countermanded, and instead the Inniskillings were marched back to a field just west of the village of Mont St. Jean to serve as a reserve to the center of the Anglo-Allied line. They reached that position at 1100, and were to remain there, sleeping despite the noise of battle, until the French pressure prompted Wellington to start pulling his reserves forward. Lt. Edward Drewe of the $1 / 27^{\text {th }}$ wrote that the battalion was ordered to occupy the ground in the rear, that is the village side of Mont-St.-Jean, as a reserve of column of Companies. In this order arms were piled, and the men lay down, and many of them continued to sleep until a short time past three o'clock p.m. This position was taken up about eleven a.m., and immediately the Battle began on the right towards Hougoumont, and gradually extended towards the left, apparently extremely hot in the centre on each side of the road leading towards La Haye Sainte and about the Wavre road that crossed to the left.

Our men continued as before described quite unconscious and apparently careless of the part they were shortly to take. Some of them were wounded by a few straggling shot that passed from the Enemy over or through our advanced lines, and a few killed. ${ }^{43}$

\footnotetext{
${ }^{43}$ ibid, 395-396.
} 
At about 1500 the Inniskillings and the rest of their division were ordered

forward. The combined effects of the French artillery fire, infantry attacks, and cavalry charges had depleted and exhausted the Anglo-Allied center, forcing Wellington to utilize

his reserves. Regarding a map of the battle being drawn shortly after the battle, General

Sir John Lambert described the position assumed by his brigade and the subsequent combat:

I would observe that the road to Wavre from the Brussels road is a sunken road, i.e., with high banks and a hedge on either side, also the high road from Brussels to Genappe, in the position, had high banks; and likewise, after the Enemy got possession of La Haye Sainte, they kept constantly sending small detachments to a mound close to the intersection of the Brussels road to Genappe, which forced the Hanoverian Brigade of the $6^{\text {th }}$ Division to fall back, and which would have allowed the Enemy to advance if had it not been for the square of the $27^{\text {th }}$ Regiment, as its position will point out. This mound should appear, it strikes me, as it was so important in that part of the line, and so honourable and fatal to the $27^{\text {th }}$ Regiment, which kept its formation and lost more men than any Regiment during the day, and would otherwise have afforded an opportunity to the enemy to have made an impression in a very serious part of the Line. ${ }^{44}$

Lieutenant Drewe of the Inniskillings added that the battalion

proceeded to ascend the gradual rising ground on the left of the Brussels road and close to the cross roads leading towards Wavre. On reaching this station we formed columns of Companies at quarter distance left flank to the enemy - the $4^{\text {th }}$ Regiment to the right, the 40th on the left, and both considerably in the rear of the $27^{\text {th }}$, which accounts for the few casualties in those Corps, comparatively speaking, with the 27 th, as they were in a great measure covered by the rising ground in front, whilst the $27^{\text {th }}$ was exposed from being on the highest ground to all that came. ${ }^{45}$

Both Lambert and Drewe state that the position taken by the Inniskillings was vital to the stability to Wellington's line, and that the battalion was placed in an exceptionally exposed position. At this point an exact study of both the combat situation

\footnotetext{
${ }^{44}$ Lieutenant General John Lambert, in Siborne, Letters, 392.

${ }^{45}$ Lieutenant Edward Drewe, $1 / 27^{\text {th }}$, in Siborne, Letters, 396.
} 
and the topography of the battlefield are necessary to convey the full impact of what the Inniskillings endured.

The Waterloo battlefield has changed a great deal since 1815 . Thousands of cubic yards of earth were removed from all around the battlefield to construct the Lion's Mound in the 1820s. Intended as a monument to the Dutch Prince of Orange who was wounded at the battle, the Mound's construction ruined the sunken roads and ridge lines that defined the Anglo-Allied positions. Only memoirs such as those quoted above can be relied upon to reconstruct the key terrain features.

Figure 1 is a map largely drawn from original maps produced for The Waterloo Companion by Mark Adkin. ${ }^{46}$ Some minor changes have been made based on the memoirs consulted for this thesis, but of all the maps reviewed Atkin's map seems the one which most nearly duplicates the historical battlefield. Key points which should be noted are the low rise on which the French artillery was sited, and the higher ridge held by the Anglo-Allied forces.

The Inniskillings and the rest of the $6^{\text {th }}$ Division were brought forward at 1530 , shortly after D'Erlon's infantry assault had been repulsed at great cost by the AngloAllied line. The Inniskillings assumed their post atop the ridge just prior to the great French cavalry charges. The greatest weight of the French cavalry attacks fell upon the right-center of the Anglo Allied line, but the Inniskillings felt their effects as well. The post above the sunken roads gave the Inniskillings considerable protection from cavalry attacks from their front and their right flanks, but French cavalry evidently circled around to attack them from the rear. No one from the Inniskillings wrote about their experience with the French cavalry, but Captain Sempronius Stretton of the $1 / 40^{\text {th }}$ remembered that 
"the field immediately around the $40^{\text {th }}$ was thickly scattered with horses and men of the French cavalry who repeatedly charged our squares (without making any impression) and who passing and returning between the squares of the $40^{\text {th }}, 27^{\text {th }}$, and $4^{\text {th }}$ Regiments, suffered severely from the fire of each. ${ }^{, 47}$ The brave but futile French cavalry charges prompted one soldier in the nearby $1 / 30^{\text {th }}$ to growl "here come those damned fools again." 48

While the French cavalry made little impression on the Inniskillings, the French artillery was brutally effective. Wellington utilized the ridge of Mont St. Jean to protect much of his infantry from French artillery fire. By placing his units just behind the crest of the ridge the French could see little of the Anglo-Allied army, and as artillery of the day was strictly a line-of-sight weapon most of the Anglo-Allied infantry was shielded from the worst of the strong French artillery. Line-of-sight analysis of the maps developed for this thesis supports the first-hand accounts that state that the position taken by the Inniskillings was visible to the French artillery sited to the east of the Charleroi road. Such exposure was exceptionally dangerous to the Inniskillings, as the French batteries opposite them consisted of:

$7^{\mathrm{e}}$ Cie., $2^{\mathrm{e}}$ Auxillerie d'Artillerie à Pied (6) 61b. guns, (2) 5.5 in. howitzers $7^{\mathrm{e}}$ Cie., $2^{\mathrm{e}}$ Artillerie à Pied (6) $121 \mathrm{~b}$. guns, (2) 6 in. howitzers

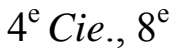
$11^{\mathrm{e}}$ Cie., $6^{\mathrm{e}}$

All four of those batteries had seen a great deal of service through-out the Napoleonic wars. The Auxillerie d'Artillerie à Pied was attached to the Imperial Guard,

\footnotetext{
${ }^{46}$ Mark Adkin, The Waterloo Companion (Mechanicsburg, PA.: Stackpole Books, 2001), 298.

${ }^{47}$ Captain Sempronius Stretton, $1 / 40^{\text {th }}$, in Gareth Glover, Letters, 292.

${ }^{48}$ Ensign Edward Macready, $1 / 30^{\text {th }}$, quoted in Keegan, Face of Battle, 140.
} 
and consisted of former navy gunners of legendary skill. The three other batteries were all heavy artillery batteries that had served in Austria, Spain, Russia, and Germany. ${ }^{49}$

From the time that the Inniskillings assumed their position at 1530 until La Haye Sainte fell at about 1830, the Inniskillings would have been subjected to the fire of the French artillery, and doubtless suffered great loss to that fire. The men welcomed the periodic advances by the French cavalry as a respite from the artillery fire, as the French gunners held their fire for fear of hitting their own men. There is no surviving commentary from the Inniskillings regarding the experience of the artillery bombardment, but Ensign William Leeke of the $1 / 52^{\text {nd }}$ Foot left a powerful description of his experience at Waterloo:

Standing to be cannonaded, and having nothing else to do, is about the most unpleasant thing that can happen to soldiers in an engagement. I frequently tried to follow with my eye, the course of the balls from our own guns which were firing over us. It is much more easy to see a round shot passing away from you over your head, than to catch sight of one coming through the air towards you, though this also occurs occasionally.... I distinctly saw the French artillerymen go through the whole process of sponging out one of his guns and reloading it; I could see that it was pointed at our square, and when it was discharged I caught sight of the ball, which appeared to be in a direct line for me. I thought, Shall I move? No! I gathered myself up, and stood firm with the Colour in my right hand. I do not know exactly the rapidity with which cannon balls fly, but I think that two seconds elapsed from the time I saw this shot leave the gun until it struck the front face of the square. It did not strike the four men in rear of whom I was standing, but the poor fellows on their right. It was fired at some elevation, and struck the front man about the knees, and coming to the ground underneath the rear man of the four, whom it most severely wounded, it rose and, passing within an inch or two of the colour pole, went over the rear face of the square without doing further injury. The two men in the first and second rank fell outward, I fear they did not survive long; the two others fell within the square. ${ }^{50}$

\footnotetext{
${ }^{49}$ Digby Smith, Napoleon's Regiments (London: Greenhill Press, 2000), 294-303.

${ }^{50}$ Ensign William Leeke, $1 / 52^{\text {nd }}$, Lord Seaton's Regiment at the Battle of Waterloo (London: Hatchard, 1866), 114.
} 
The ball that struck Leeke's square killed four men, but the damage could be much worse. The trajectory of the ball and the angle at which it struck a body of men could greatly amplify the damage. Further, a cannon ball striking a body of men could turn equipment, muskets, bayonets, and indeed body parts into missiles that could wound and kill even more men. Captain Sempronius Stretton of the $1 / 40^{\text {th }}$, stationed just to the left rear of the Inniskillings at Waterloo, wrote that,

towards the evening, whilst the Regiment was in open column, a round shot from the Enemy took off the head of a Captain (Fisher) near me, and striking his Company on the left flank, put hors de combat more than twenty-five men. This was the most destructive shot I ever witnessed during a long period of service. ${ }^{51}$

The artillery fire that raked the ranks of the Inniskillings between 1530 and 1830 killed and wounded scores of men in terribly violent ways. The power of the French artillery and its effects are confirmed by Lieutenant James Mill of the $1 / 40^{\text {th }}$, who was stationed just behind the Inniskillings:

A very tremendous cannonade was commenced by the French on our lines, and uninterruptedly continued. We lay down in square to escape as far as possible its destructive effects. Half the Inniskillings were mowed down in a similar position, without having the power to return a shot. At one time the officer commanding the Twenty-Seventh, when there was temporary cessation from artillery, rode up to our major, and announced the fact of having barely an officer to command each company. Major Browne offered to lend him some from the Fortieth. This, however, was imperatively declined. "The sergeants of the regiment," he said, "like to command the companies, and he would be loathe to deprive them of the honour." Whenever there was an intermission in the fire, it was to find ourselves surrounded and beset by hordes of horsemen, who were slashing and cutting at our kneeling ranks. The file of our standing ranks, being concentrated and constant, was very effectual against their attacks, and both horse and rider were to be constantly discerned rolling over onto the plain, and the remainder flying back in disorder to their own lines. ${ }^{52}$

${ }^{51}$ Captain Sempronius Stretton, $1 / 40^{\text {th }}$, in Siborne, Letters, 400.

${ }^{52}$ Lieutenant James Mill, $1 / 40^{\text {th }}$, quoted in Regimental Historical Records Committee, The Royal Inniskilling Fusiliers from December 1688 to July 1914 (London: Constable and Company Ltd., 1934) 263. 
While the British squares were able to fend off the French cavalry with comparative ease, the presence of the cavalry forced the Inniskillings to remain in square formation. A square was an exceptionally dense formation and cannon fire could be especially devastating, as one ball could strike many men.

At approximately 1830 the farm of La Haye Sainte fell to the French. The thousands of French troops who had besieged the farm were loosed upon the center of the Anglo-Allied line, and

this, however unavoidable, was highly disastrous to the troops of Picton and Lambert, for the French instantly filled the house with sharpshooters, whose deadly fire precluded the possibility of holding the knoll and the ground immediately about it, and they established also a strong and numerous line of Infantry, extending along the front of Kempts' Brigade. ${ }^{53}$

As French infantry swarmed forward, the lethal French artillery fell silent, again fearful of their fire striking their own men. From 1830 until the close of the battle, the Inniskillings instead suffered from close-range infantry fire. The Inniskillings still held their post atop the ridge, while the $95^{\text {th }}$ Rifles held the sunken road below them. Rising above the sunken road, opposite to the Inniskillings, was the knoll upon which the French infantry fired from solid cover upon the Allied line. The Rifles, in loose order, had substantial cover behind the hedges lining the sunken road. The Inniskillings, in close order in the open, were hopelessly exposed.

The French infantry who were firing on the Inniskillings were, like the artillerymen who had been bombarding the ridge, very experienced soldiers. The men who had finally captured La Haye Sainte and who were now surging up the ridge toward the Inniskillings were from the $2^{\text {nd }}$ Division of I Corps, commanded 
Figure 1. The situation of the $1 / 27$ at The Battle of Waterloo, June 18, 1815, about $1900 .{ }^{54}$

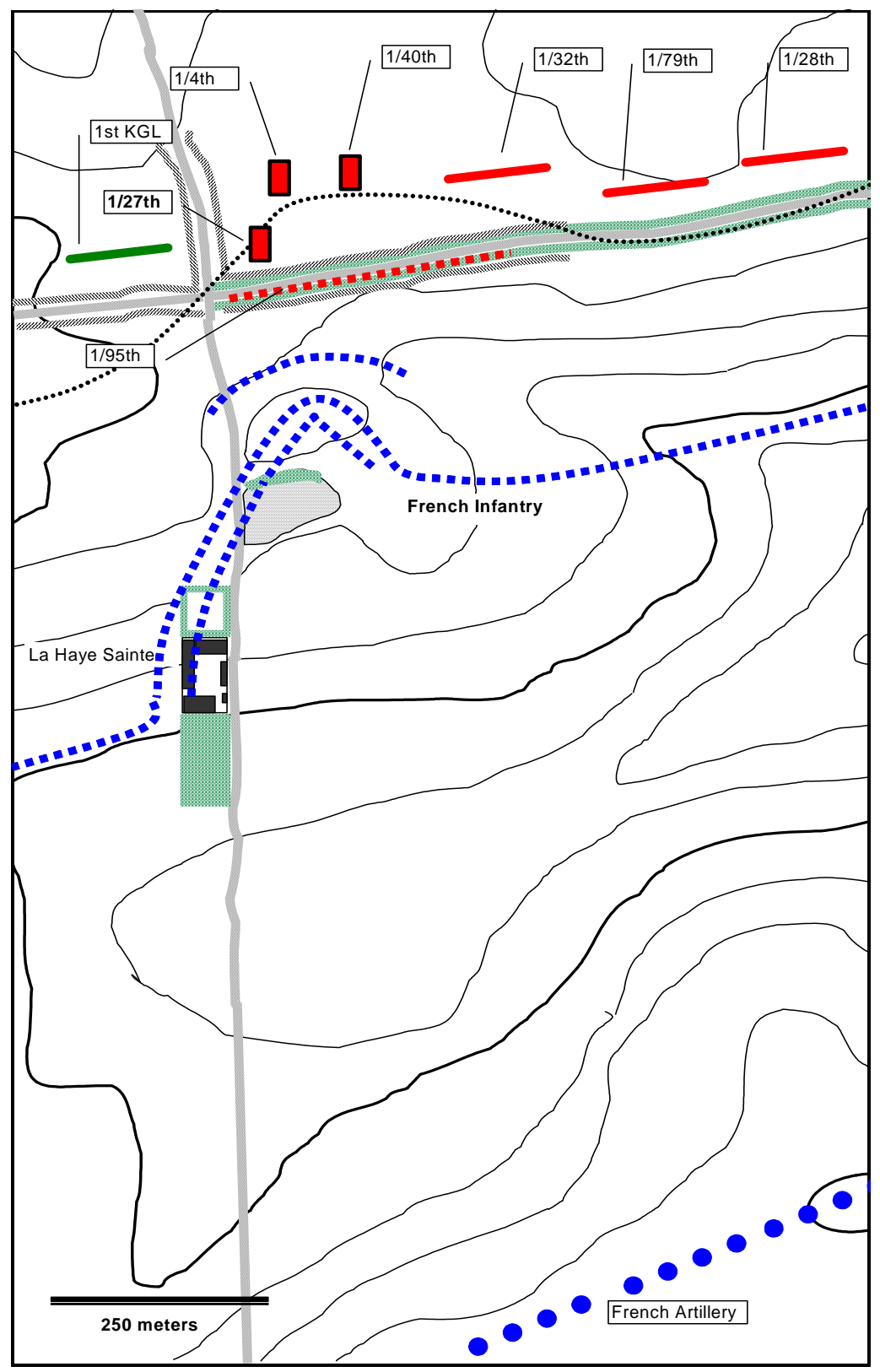

${ }^{53}$ Captain Jonathan Leach, $1 / 95^{\text {th }}$, in Siborne, Letters, 364.

${ }^{54}$ Map compliled from Mark Adkin, Waterloo Companion, 357, 369, Scott Bowden, Armies at Waterloo, 32, and Peter Hofschroer, 1815: The Waterloo Campaign, 132. 
by the formidable Général de Division Baron Donzelot. Foremost in Donzelot's division were the three battalions of the $13^{e}$ Régiment d'Infanterie Légère, veterans of many of the great battles of the era, including Austerlitz, Jena, Wagram, and Borodino. ${ }^{56}$

The Inniskillings were an easy target for the French infantry as they were still deployed in square, even though the threat of French cavalry attack was minimal. Fear of a French move up the Brussels road led the Inniskillings to remain in square so that one side of their square would face the French upon the knoll, while another face of the square would face the Brussels road, and discourage any French move north. Captain John Leach of the Rifles confirms this, as he explained that as the exchange of musketry around the knoll,

was the closest and most protracted almost ever witnessed, some apprehension was entertained that the French would endeavor to force their way along the chausée, and attack the rear of the troops lining the thorn hedge, and on a report of the kind being made to me by one of our Officers, coupled with a suggestion that a part of the $95^{\text {th }}$ Riflemen should be concentrated on the extreme right, so as to fire into the road, my reply was, "The $27^{\text {th }}$ Regiment is in square in our rear, having one of its faces looking into the road, and that Regiment must protect our rear."

Numerous primary sources mention the fire directed upon the Inniskillings and their resultant casualties. This is remarkable, as a close reading of the available memoirs reveals that most diarists wrote only about their own battalion's experience, without mentioning other formations. For so many men from other battalions to mention the Inniskillings reflects the extraordinary punishment taken by the $1 / 27^{\text {th }}$.

Lt. Colonel Sir Andrew Barnard of the Rifles confirmed that "the $27^{\text {th }}$ were formed in square at a very short distance in the rear of the $5^{\text {th }}$ Division, and suffered very

\footnotetext{
${ }^{56}$ Digby Smith, Napoleon's Regiments, 192-193.

${ }^{57}$ Captain Jonathan Leach in Siborne, Letters, 366.
} 
much from the Enemy's fire." ${ }^{, 58}$ Major Felix Calvert wrote that late in the evening, "the $27^{\text {th }}$ having nearly lost all its men," ${ }^{59}$ the $1 / 32^{\text {nd }}$ Foot had to hold a section of the Wavre road until it joined the rest of the Army in its final advance. Lieutenant John Kincaid of the Rifles wrote that that at the close of the battle "the twenty-seventh regiment were literally lying dead, in square, a few yards behind us.

The Inniskillings' ordeal came to an end at about 2000. The general advance of the Allied army was ordered by Wellington as the attack of the French Guard was driven back from the ridge between La Haye Sainte and Hougomont. When the Guard retreated the French quickly evacuated La Haye Sainte, and the "British line moved forward, the $40^{\text {th }}$ drove the Tirailleurs from the rising ground in its front, and occupied it; at the same time the $27^{\text {th }}$, with Grenadiers of the $40^{\text {th }}$, took possession of the farm of La Haye Sainte, in which they made prisoners of a General Officer and a party of the enemy." ${ }^{, 1}$

Numerous sources agree on the vital nature of the position held by the Inniskillings, the lethal French fire directed on them, and the terrible losses that they suffered. And even if the Inniskillings were not "literally lying dead," as their subsequent advance into La Haye Sainte attests, the casualty returns verify that the regiment suffered terribly. Their percentage of loss was the worst of any Allied unit at Waterloo. ${ }^{62}$

Who were these men of the First Battalion of the $27^{\text {th }}$ Foot who endured such terrible punishment?

\footnotetext{
${ }^{58}$ Lt. Colonel Sir Andrew Barnard, 1/95 ${ }^{\text {th }}$, in Siborne, Letters, 362.

${ }^{59}$ Major Felix Calvert, $1 / 32^{\text {nd }}$, in Siborne, Letters, 352-353.

${ }^{60}$ Captain John Kincaid, 1/95 ${ }^{\text {th }}$, Adventures in the Rifle Brigade (Glasgow: Richard Drew, 1981), 172-173.

${ }^{61}$ Captain Sempronius Stretton, in Siborne, Letters, 401.
} 


\section{THE MEN}

\section{Background}

While many specific details concerning the men who served at Waterloo will never be known, what information is available can help humanize the men of the battalion. Private Alexander Dunlop, for example, was born in 1786 in the parish of Aughavea in the County Fermanagh. He worked as a laborer until his enlistment with the $27^{\text {th }}$ at Enniskillen in 1807, at age 21. Dunlop was five feet seven inches tall, with brown hair and grey eyes. His face was round, his complexion swarthy, and when he enlisted he agreed to an unlimited period of service in the army. ${ }^{63}$

With an enlistment date of 1807, Private Dunlop would have served through much of the Inniskillings' service in Spain, as well as the war against the Americans in early 1815 . As the $1 / 27^{\text {th }}$ arrived in Belgium, Dunlop served in the $9^{\text {th }}$ Company, and based on the seniority of the officers it is likely that the $9^{\text {th }}$ Company was commanded by Lt. Edward Drewe. Drewe had been a Lieutenant in the 1/27th since 1808, and was badly wounded at Waterloo, being hit in the left knee and arm. ${ }^{64}$

Lt. Drewe eventually was granted an annual pension of $£ 70$ for his wounds, while Private Dunlop survived Waterloo unscathed. Dunlop stayed in the $1 / 27^{\text {th }}$ until 1829 ,

\footnotetext{
${ }^{62}$ Scott Bowden, Armies at Waterloo, 228-268.

${ }^{63}$ United Kingdom War Office, Description Book, $27^{\text {th }}$ Foot, WO 25/356.

${ }^{64}$ Regimental records, Inniskilling Museum, Enniskillen, Northern Ireland.
} 
when he was finally discharged as "unfit for service" with a daily pension of $10 \mathrm{p}$. to sustain him.

Facts such as these can bring the men of the $1 / 27^{\text {th }}$ to life. They were men of different backgrounds, but they were all destined to serve together atop the ridge at Waterloo. To fully reflect the human element in war, there is no better way than to know all that can be learned about those men, and try to understand their motivations.

For hundreds of years before Waterloo, and for many years afterward, Ireland was a land of recurrent conflict. Ireland's early history was an oral tradition of great warriors and epic battles. Too much Irish "history" cites the myth and magic of such oral histories as truth, but the Irishmen who served at Waterloo were raised on such stories, and it formed part of their psyche. ${ }^{65}$ All Irish children heard stories such as "The Battle of the White Strand" where Daire Donn, the High King of the Great World, and his mighty host were defeated at great cost by the heroes of Ireland. The famous Finn MacCool and his warrior band, the Fianna, led the Irish forces that destroyed the Army of the World, but only after most of their own men fell. Dead heroes were deeply mourned in the wailing tradition of grieving Irish, and their great deeds were heralded far beyond the day of their deaths. Epic poems were written for the dead heroes. Credhe, the widow of the fallen hero Cael, grieved,

Sorrowful to me, O sorrowful to me the death of the hero that lay beside me; the son of the woman of the Wood of the Two Thickets, to be with a bunch of grass under his head.

\footnotetext{
${ }^{65}$ See, for example, Seamus MacManus, The Story of the Irish Race (New York: The Devin-Adair Company, 1921).
} 
Sore be to me, $\mathrm{O}$ sore to me Cael to be a dead man beside me, the waves to have gone over his white body, it is his pleasantness that has put my wits astray. ${ }^{66}$

Such stories and poems were passed on from generation to generation of Irish men and women. The Irishmen who served in the Inniskillings came from a culture that honored brave men who fought and died in battle.

The Irish warrior tradition notwithstanding, the Irish had long struggled against the domination of the English. The first efforts at English control of Ireland came in 1169, and by 1230 two-thirds of Ireland was controlled by English settlers. Only the strongest Irish clans successfully resisted the English; the MacCarthys and O'Brians in the southwest, the O'Connors in west, and the O'Neills in the north. While Irish resistance was stout, the failure of the English to completely conquer Ireland during this period was partially due to lack of interest by the English, who were distracted by burgeoning issues in continental Europe. This lack of interest started the tradition of absentee landlords that plagued Ireland for centuries, as landowners with no ties to their land or its people bled the land white. Further, the survival of some of the Irish aristocracy left in place a minority power base that kept alive a sputtering flame of hope for a return to Irish rule. Various parts of the old Irish aristocracy served as the focus of rebellions in $1534,1595,1641$, and $1798 .^{67}$

Each of the rebellions of the Irish was met by harsh repressions by the English. In the 1590 s a system of land confiscation and plantation was begun that displaced the native Irish. Oliver Cromwell's punitive expedition to Ireland in 1649 was financed by

\footnotetext{
${ }^{66}$ Lady Augusta Gregory, Irish Myths and Legends (Philadelphia: Running Press, 1998) originally published as Gods and Fighting Men (London: John Murray, 1910), 236.

${ }^{67}$ Sean Duffy, The Concise History of Ireland (Derbyshire: Arcadia Editions Limited, 2000), 98-131.
} 
promises of Irish lands to English lords. ${ }^{68}$ In 1641 about $60 \%$ of the land of Ireland was controlled by Irish Catholics; by the end of Cromwell's excesses in 1658 that percentage had dropped to 20\%. Displaced Irish Catholics were forced from their ancestral lands and given non-arable tracts in the west, hence Cromwell's derisive phrase, "To Hell or Connacht. ${ }^{.69}$

This long-term process of land confiscation was done in concert with an effort at Anglicization, during which the Irish dress, language, and culture were to be replaced by English equivalents. Some of these changes were mandated by law, but in many cases the native Irish were willing to adopt English ways in order to do business with the English. Eventually the old ways were seen only in the most remote parts of the north, west, and far southwest. ${ }^{70}$

Another aspect of the English attempts to control Ireland was through religion. Since the reign of Henry VIII, loyalty to the Anglican Church had been a mark of loyalty to the British Crown. The Irish were seen as being far different from the English; "to the English people, the Irish had always been such an 'other.' After the Reformation, Catholics too formed an easy target (with the Irish doubly damned)." ${ }^{, 71}$ The English Civil War of 1642 reinforced the notion that Catholicism was tantamount to disloyalty, and Irish Catholic support for James II during the Glorious Revolution made Irish Catholicism especially traitorous in English memory. ${ }^{72}$ The parliamentary commissioners who were brought to Ireland in 1652 to support Cromwell's settlement

\footnotetext{
${ }^{68}$ Liam de Paor, The Peoples of Ireland, (Notre Dame: University of Notre Dame Press, 1986), 157.

${ }^{69}$ Sean Duffy, Concise History of Ireland, 116-118.

${ }^{70}$ ibid., 106.

${ }^{71}$ Wayne E. Lee, Crowds and Soldiers in Revolutionary North Carolina (Gainesville: University Press of Florida, 2001), 110.

${ }^{72}$ Barbara Donegan, “Codes and Conduct in the English Civil War," Past \& Present \#118 (1988), 71.
} 
reflected the worst of that bias. While the commissioners were suspicious of the Scottish Presbyterians in Ulster, their efforts were concentrated on the Catholic clergy, many of whom were killed, imprisoned, or exiled.

Irish Catholic support of James II in 1689 led to defeats at the Battle of the Boyne and at Limerick, and the subsequent flight of much of the Irish aristocracy. The removal of many of the Irish Catholic nobles ensured the supremacy of the Protestant minority, and further tainted the whole of the Irish Catholic population with a reputation for disloyalty and barbarism. Ireland was only separated from England by the narrow Irish Sea, but the gulf between the two peoples was enormous. That gulf was widened by the Penal Laws that were enacted during the seventeenth and eighteenth centuries to suppress the religious and societal rights of the Catholics. The native Irish "were disenfranchised and debarred from all political or legal office, and they could not acquire or bequeath land or property."73 The Penal Laws were de jure attempts to restrict the Catholic religion, bar Catholics from owning weapons, and even limit the quality of horses which could be owned by Catholics. The Penal laws reached into many aspects of everyday life: for example, any marriage between a "Papist and any person who has been a Protestant shall be absolutely null and void." ${ }^{, 74}$

Ireland in the late eighteenth century was a product of the previous centuries of conflict. Ninety-five percent of the land was controlled by five percent of the population, the

\footnotetext{
${ }^{73}$ Irish Statutes, The Statutes at Large passed in the Parliaments held in Ireland (Dublin: George Grierson, 1786-1801.Vols. III - VII) 19 Geo II c.13 (1745) <http://law.umn.edu/irishlaw/.html>

${ }^{74}$ ibid.

${ }^{76}$ Marianne Elliott, Partners in Revolution: The United Irishmen and France (New Haven: Yale University Press, 1982), 8, and Thomas Packenham, The Year of Liberty (Englewood Cliffs, N.J.: Prentice-Hall, 1969), 26.
} 
"small, selfish, and corrupt oligarchy" of Anglo-Irish Protestant elites. ${ }^{76}$ The Protestant elite consisted primarily of Anglicans, members of the Church of Ireland. The other part of the Protestant population consisted of the Dissenters, the Presbyterians and Methodists who were concentrated mostly in Ulster. While both Presbyterianism and Methodism were Protestant religions, only Anglicans were considered truly entitled members of the Anglo-Irish elite. The sectarian divisions of the eighteenth century cannot be simplified into a Catholic/Protestant split, as there were deep divisions within Protestantism that could be as deep as those between Protestants and Catholics. While the Penal laws were primarily aimed at controlling Catholics, Dissenter churches such as Presbyterians and Methodists also felt their effects.

The Dissenters were primarily transplants from Scotland and England, and were quite well acclimated into Irish culture. ${ }^{77}$ While most of the Protestant elites considered themselves "English," the Dissenters considered themselves "Irish." But as nonCatholics the Dissenters were never entirely accepted by the native Catholics, and as nonAnglicans they were never fully trusted by the Protestant elites. They made up about twenty-five percent of the population, and were the backbone of the burgeoning Irish middle class, particularly in the growing linen industries that took root in Ulster. ${ }^{79}$

Ireland in the early eighteenth century was deceptively quiet. The Penal Laws were in place, and "a century of peace and some prosperity- for the Protestantssucceeded. ${ }^{, 80}$ The population was fragmented by religion, language, education, culture, and background. Not surprisingly, as the century wore on Ireland became an increasingly

\footnotetext{
${ }^{77}$ Tony Crowley, Wars of Words : The Politics of Language in Ireland 1537-2004 (Oxford : Oxford University Press, 2005), 65.

${ }^{79}$ Liam de Paor, The Peoples of Ireland, 215.

${ }^{80}$ Thomas Pakenham, Year of Liberty, 26.
} 
violent place. There was conflict between current elites, former elites, and those with frustrated claims to elite status. Dueling was endemic. ${ }^{81}$ Further, as the century went on the incidence of assault, rape, and murder all rose substantially. The murder rate in County Armagh was four times the rate seen in England's Kent County. ${ }^{82}$ By the end of the eighteenth century the rising crime rate was a barometer of the tensions and poverty festering in Irish society.

After the American and French Revolutions, many of the Anglican elites became enamored of Enlightenment ideology, and clamored for liberty and separation from English domination. As is often the case, this elite led movement for independence did not advocate independence for everyone; the new Ireland was to be free of English influence, but was still to be completely dominated by the elite Anglican minority. The Catholics of Ireland were to remain disenfranchised. ${ }^{83}$

The Protestant reformers founded the United Irishmen, and their toil, squabbling, and dreaming eventually resulted in the bungled Rebellion of 1798. Most of the leadership of the United Irishmen had been arrested or backed hurriedly away from the Rebellion before it flared up. When violence did break out, the atrocities and counteratrocities were horrendous. A tiny French invasion force landed in Mayo serving merely to prolong and heighten the bloodshed.

\footnotetext{
${ }^{81}$ James Kelly, “That damn'd thing called honour”: dueling in Ireland, 1570-1860 (Cork: Four Courts Press, 1995)

${ }^{82}$ Neal Garnham, "How violent was eighteenth century Ireland?" Irish Historical Studies, xxx. No.119 (May 1997), pp. 377-392.
} 
Figure 1.

Ireland county map ${ }^{84}$

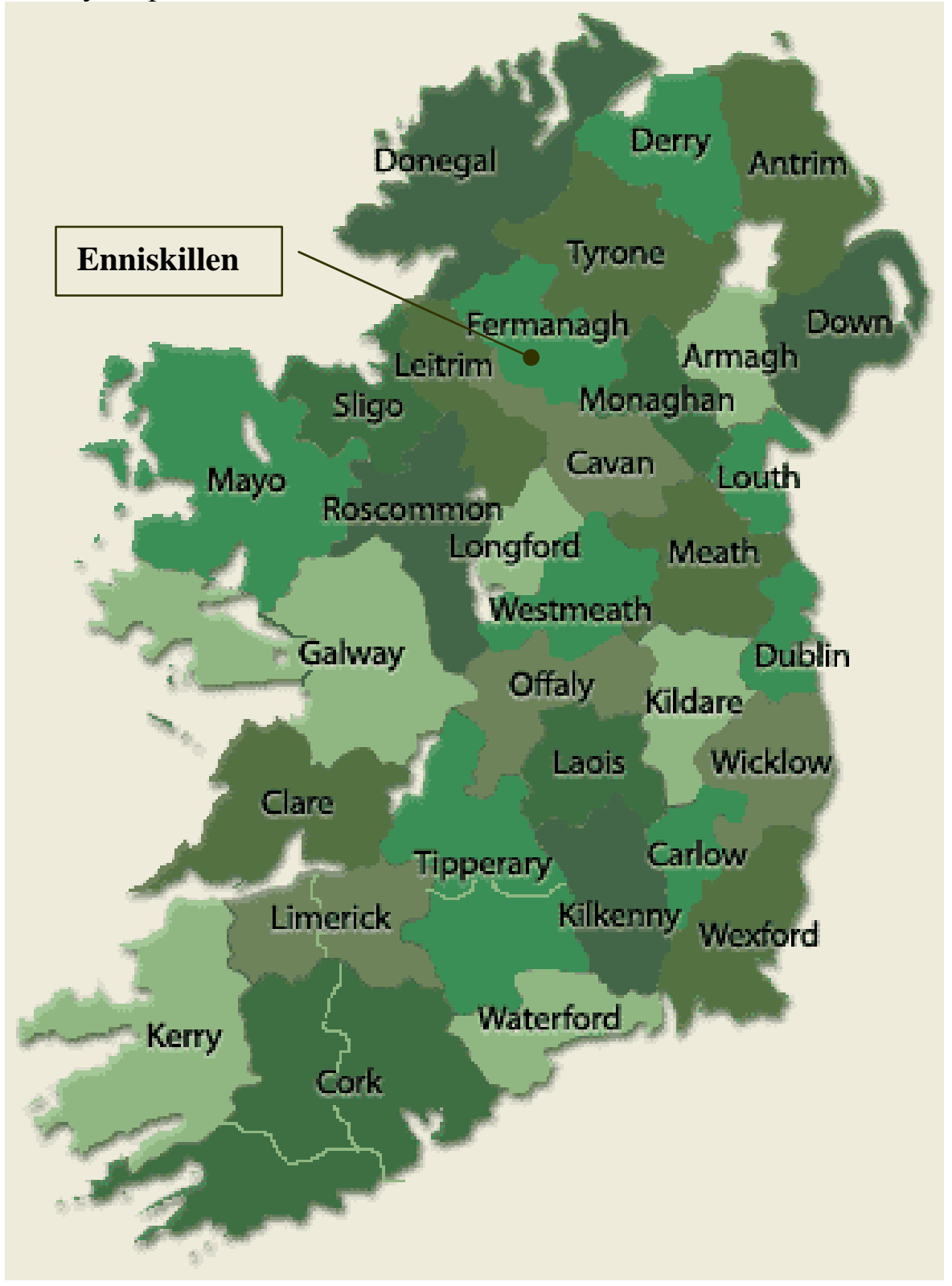

Since the Middle Ages Ireland had consisted of two nations in one land, and in the following years "they had not been drawn together. On the contrary, for a century they had been harshly separated on terms of inequality by law and custom, and now were

\footnotetext{
${ }^{83}$ Marianne Elliott, Partners in Revolution, 286.

${ }^{84}$ From Wikipedia On-line Encyclopedia: http://en.wkipedia.org/wiki/Counties_of_Ireland
} 
further divided by the mutual spilling of blood. ${ }^{185}$ The divisions that lay dormant through most of the eighteenth century were suddenly terribly obvious.

This was the environment in which the men of the $1 / 27^{\text {th }}$ were raised. It was an environment of conflict, inequality, great wealth, and great poverty. Irish men went to war for many reasons. While we have few records regarding their personal backgrounds and motivations, there is societal data that can be utilized in an attempt to know them better.

\section{Societal data}

To understand the men of the First Battalion of the Inniskilling Regiment and their reactions to the experience of Waterloo, one must begin with as much of their background as can be gathered. The pay rosters and recruiting rosters can be searched for pertinent information, and the Irish Census data of 1831, 1841, and 1851, and 1861 can provide a great deal of detail as to who these men were, and what their world was like. ${ }^{86}$

The national origin of the men who comprised the $1 / 27^{\text {th }}$ at Waterloo is of prime concern to this thesis. Most British regiments of the day bore a territorial designation; the 30th Foot, for example, was the Cambridgeshire Regiment, while the $32^{\text {nd }}$ was the Cornwall Regiment. But regiments of the Revolutionary and Napoleonic Wars had great difficulty in recruiting enough men in their home territory, and ranged all across England, Ireland, and Scotland to recruit enough men. The $1 / 27^{\text {th }}$ was designated the Inniskilling Regiment, and was thus one of the few Irish regiments of the day. Was the battalion that fought at Waterloo indeed Irish in composition?

\footnotetext{
${ }^{85}$ Liam de Paor, Peoples, 215-217, 223.

${ }^{86}$ All Census data in this section from Clarkson, L.A. et al., Database of Irish Historical Statistics.
} 
Surviving recruitment records for the $27^{\text {th }}$ Foot were scoured to locate the names of the men who served at Waterloo. ${ }^{87}$ Of the 730 men in the battalion, the birthplaces of 273 could be discerned with accuracy.

\section{Table 3.}

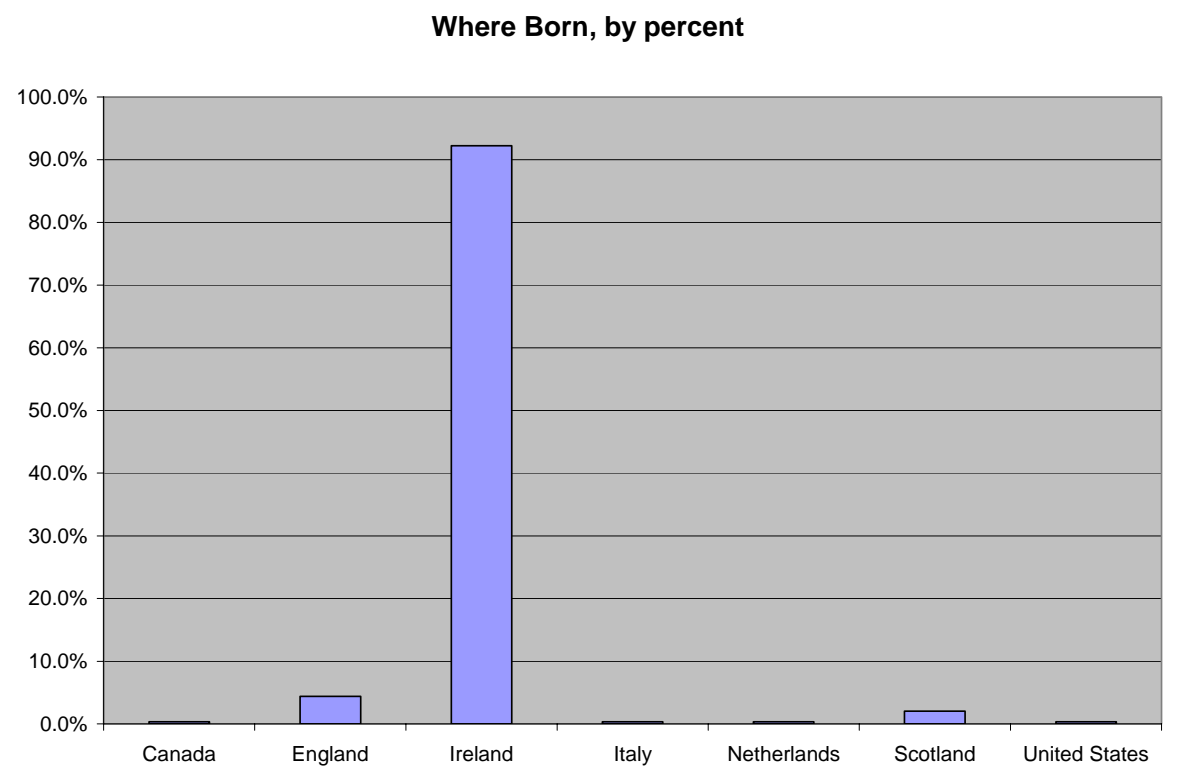

As can be seen in the graphed data, more than $90 \%$ of the men were of Irish birth; 4\% from England, and 2\% from Scotland. The birthplace of the entire battalion can be extrapolated by applying those percentages to all $730 \mathrm{men}$. While this extrapolation is not as accurate as the actual data, it is the best approximation possible due to the lack of the necessary hard data. The primary source for the personal data for the men of the $1 / 27^{\text {th }}$ is the Description Book kept by the regiment. But it is obvious that the Description Book was drawn up well after Waterloo, as there are no entries for men who were killed at Waterloo, and many of the wounded men were omitted as well. While the omission of data on men who became casualties is frustrating, there are no indications that their

\footnotetext{
${ }^{87}$ United Kingdom War Office, Description Book, $27^{\text {th }}$ Foot.
} 
background information was any different from those who lived to have their information entered into the Description Book. Extrapolation of the available data is a fair and honest method to determine the background of the entire battalion.

\section{Table 4.}

Full Battalion Place of Birth, Extrapolated

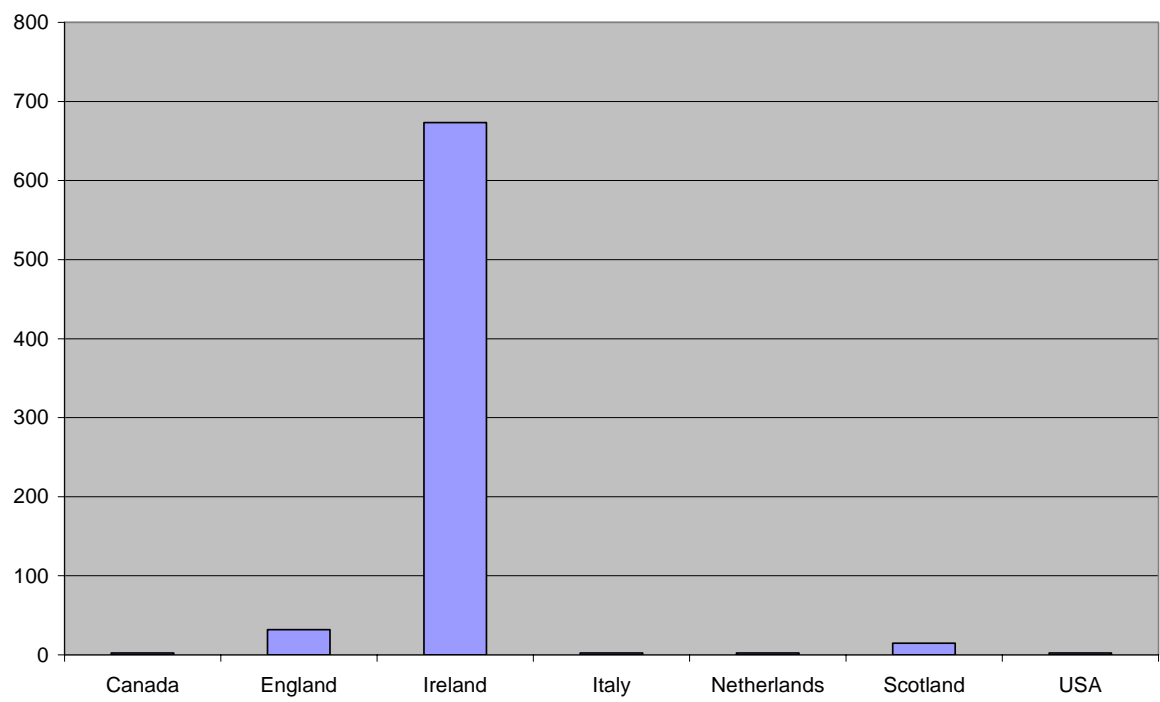

Using the same methodology, the county of birth of the Irish can also be extrapolated. Table 5.

Full Battalion County of Birth, Extrapolated

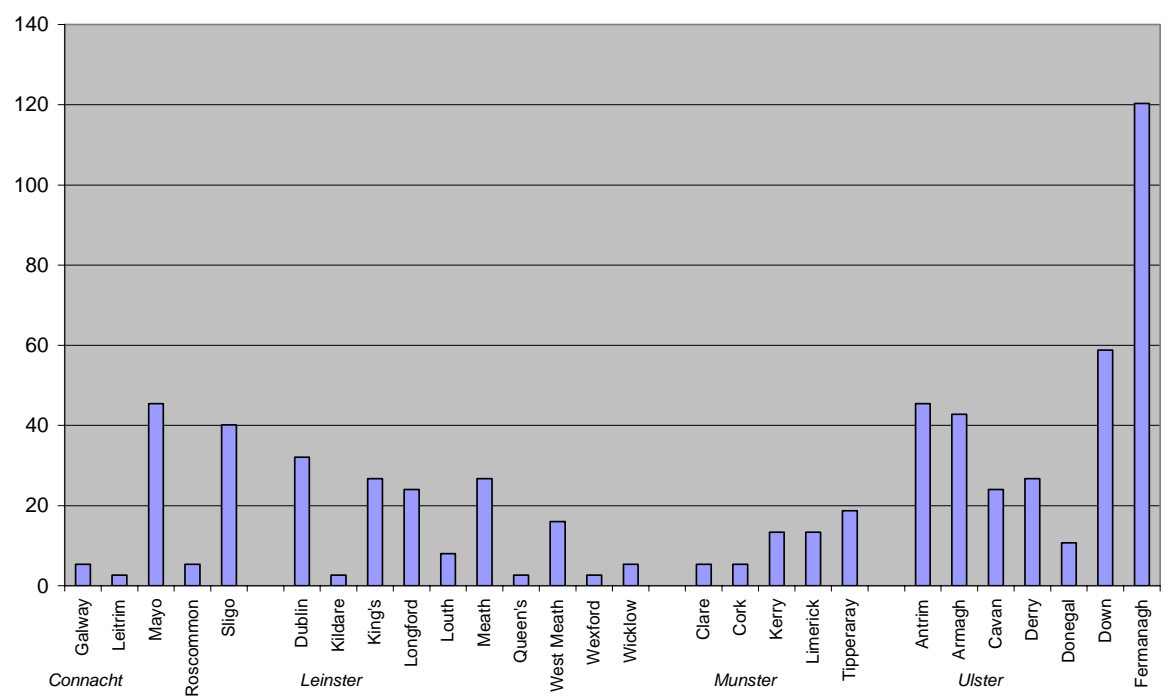


More personal data for the men can be pulled from the census records. The census data is of spectacular depth and breadth, and choices had to be made as to which portions of the data to utilize to help illuminate the men of the $1 / 27^{\text {th }}$ and their world. Religion was, and still is, a major issue in Ireland, and the census data can give valuable perspective into the lives of all Irish people, and the Inniskillings in particular. Literacy and language data is also available, and can further explain critical aspects of Ireland, its people, and its soldiers.

\section{$\underline{\text { Religion }}$}

There was an enormous anti-Catholic ethos in eighteenth- and early nineteenthcentury England. Outbursts of sectarian violence in England were obvious evidence of anti-Catholic feelings. London's Gordon Riots of 1778 were instigated in response to the Catholic Relief Act. Rioters roamed the city for more than a week crying "No Popery!" ${ }^{88}$ Troops were sent in to quell the riots only after the violence spread to those people and institutions not involved in the support of Catholic emancipation, hinting that some elements of civil authority, including some army officers, were in support of the rioters' motives.

The Catholic Relief Act of 1791, similar to the act that had sparked the Gordon Riots, contained a clause to once again allow Catholic men and officers to join the British army, though the restriction had not been strictly enforced for some time. ${ }^{89}$ As the Revolutionary Wars dragged on the British army had increasing difficulties in filling the ranks, and the army quickly made use of the now-official opportunity to enlist Catholics. An officers' guide published in 1800 stated that "the taking of the sacrament according to

\footnotetext{
${ }^{88}$ Julius R. Ruff, Violence in Early Modern Europe (Cambridge: Cambridge University Press, 2001) 200201.
} 
the rites of the established Church of England, with the oath of supremacy, being now dispensed with, gentlemen of the Roman Catholic persuasion find no difficulty in entering into the British army." "S0 Similarly, the same guide reflected changes in the enlisted man's oath:

It is directed, by instructions from the War Office, that, in certain cases, the words - I am a protestant, should be omitted. This regulation has done away the many obstacles, which have so materially hurt the recruiting service, by excluding able men on account of their religious opinions. $^{91}$

While the War Office was willing to alter its standards to draw Catholics into the ranks, its liberality was not shared by many men in the army. Instances of religious intolerance are not rare in the memoirs of British officers, though they are very uncommon in the papers of British enlisted men. The devout Anglican Lieutenant Charles Crowe of the Inniskillings exemplified disdain for Catholicism while the regiment was in Spain. While touring Madrid, Crowe entered a cathedral during Mass, and his reaction to the Catholic rite was very decided: "disgust, was my prominent feeling; and I retired as quickly as possible, returned to my billet, opened my portmanteau for my prayer book and fervently read the morning service of my own Church." ${ }^{92}$ Captain Cavalié Mercer of the Royal Horse Artillery was not a religious man, but he was an inveterate snob; when he toured a Catholic cathedral in Belgium in 1815, his reaction was similar to that of Lt. Crowe. While appreciative of the architecture, Mercer loathed

\footnotetext{
${ }^{89}$ Philip Haythornthwaite, The Armies of Wellington (London: Arms and Armour Press, 1994), 48.

${ }^{90}$ Charles James, The Regimental Companion, Volumes I and II (London: T. Egerton, 1800), 47.

${ }^{91}$ ibid., Vol. II, 420.

${ }^{92}$ Lieutenant Charles Crowe, Memoirs, 16.
} 
the ceremony: "priests in embroidered robes were celebrating mass with a solemnity which rendered still more ridiculous their repeated genuflexions." 93

Wellington's attitudes toward the Catholics of Ireland were demonstrated through his steadfast opposition to Catholic Emancipation. Wellington's post-war political career was a case-study in the aristocratic defense of the status-quo. When addressing Parliament on Catholic Emancipation in 1828, Wellington said that "there is no person in this House whose feelings are more decided than mine with regard to the subject of the Roman Catholic claims; and until I see a great change in that quarter, I certainly shall oppose it." ${ }^{94}$ As the British officer corps was dominated by Wellington and other "gentlemen" of property and status, the army remained conservative, tradition-bound, and disdainful of religious difference.

There are no reliable census data available for religious affiliation in 1815 , but the Census of 1861 provides detailed, nation-wide survey results. ${ }^{95}$ While the population of Ireland grew dramatically in the early $19^{\text {th }}$ century, the Famine and mass emigration reduced the population of 1861 Ireland to $6,400,000$, very close to the $6,281,000$ of $1815^{96}$

\footnotetext{
${ }^{93}$ Captain Cavalié Mercer, Journal, 24.

${ }^{94}$ Wellington, quoted in Elizabeth Longford, Wellington: Pillar of State (New York: Harper and Row, Publishers, 1972), 166.

${ }^{95}$ Clarkson, L.A. et al., Database of Irish Historical Statistics: Religion: 1861-1911.

${ }^{96}$ B. R. Mitchell, Abstract of British Historical Statistics (Cambridge: Cambridge University Press, 1961), 201.
} 
Table 6.

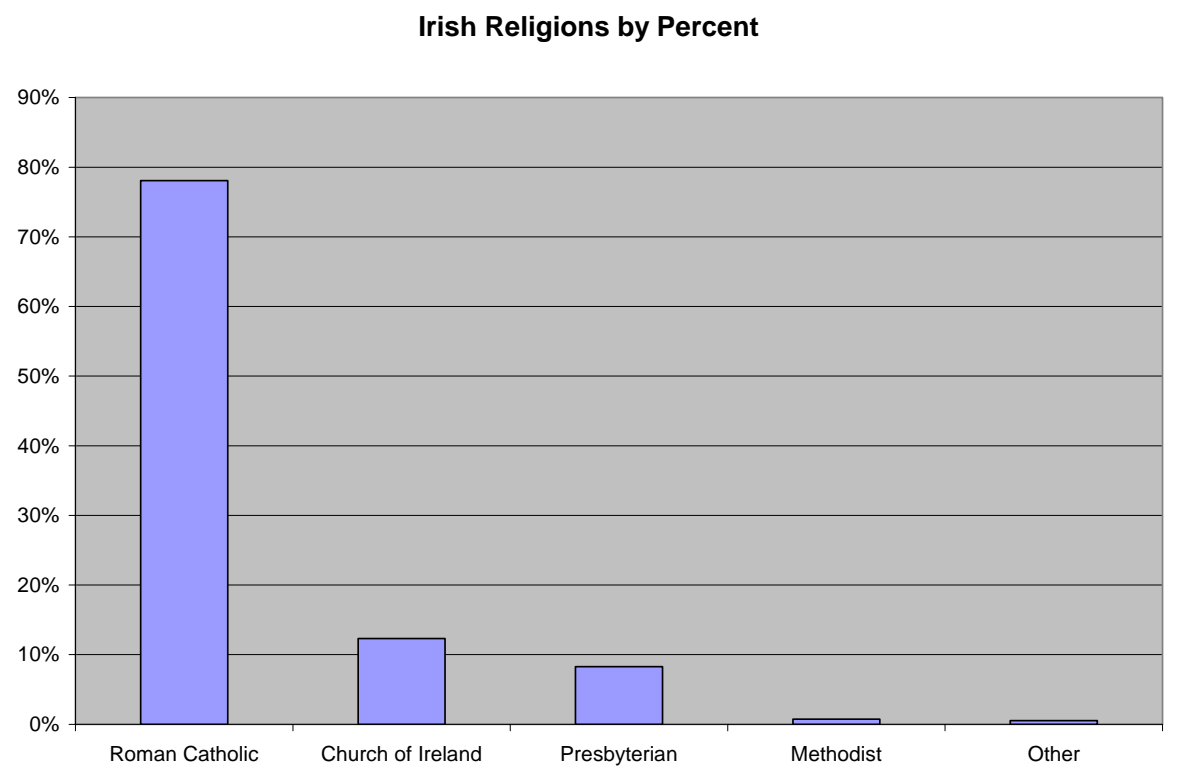

While Catholicism was the dominant national religion, there were several counties where Protestant communities were particularly strong. In the three southern provinces of Munster, Connaught, and Leinster, the Catholics held a vast majority, though the cities of Cork and Dublin had at least a moderate Church of Ireland minority. In Ulster, however, there was a diversity of faith that was unknown elsewhere in Ireland. In Antrim and Down the strong Scottish community gave the Presbyterian denomination a majority voice, while in almost every Ulster county Protestants constituted a significant portion of the population. 
Table 7 .

Religious Affiliation of Ireland by County, by Province

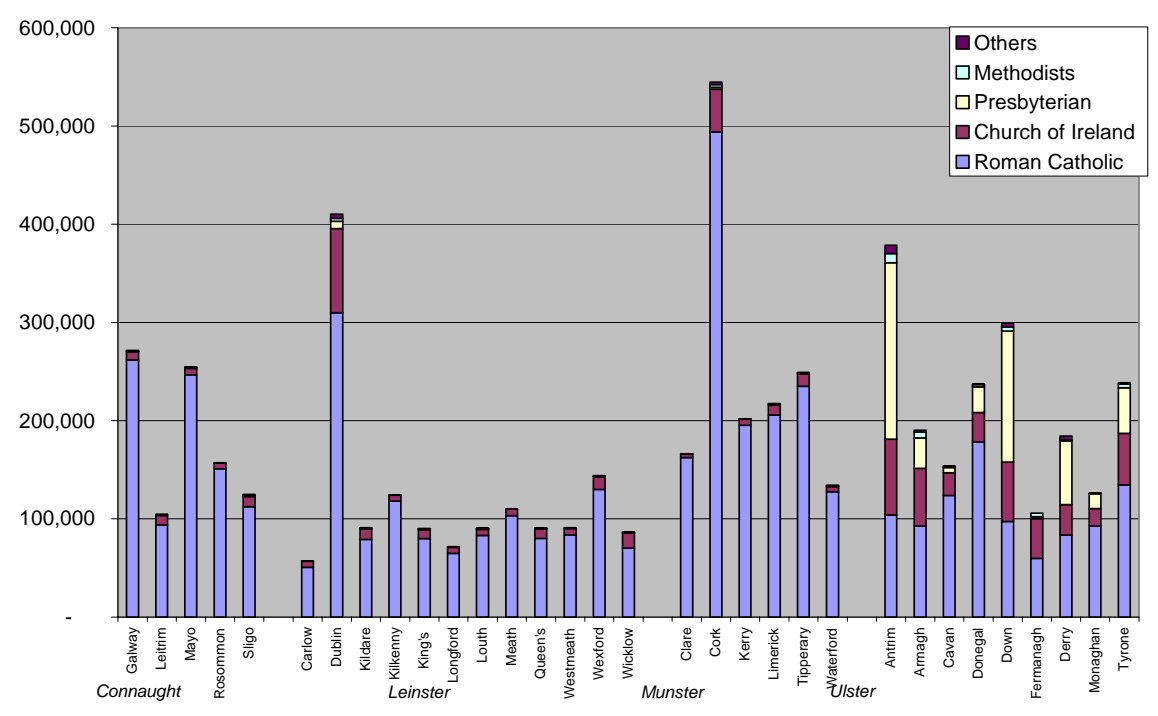

There is no record of the religious affiliation of the men of the $1 / 27^{\text {th }}$ in 1815 . It is possible, however, to extrapolate a reliable estimate by using the "religion by county" data above with the "birthplace by county" data presented earlier. The predominance of Ulstermen in the ranks of the Inniskillings meant a stronger representation of Protestant denominations in the battalion than was seen in the general Irish population. Still, the data shows that Catholics in the ranks would still have outnumbered Protestants by two to one. 
Table 8 .

Religious Affiliation of 1/27th, in percent, based on extrapolation of birthplace/religion by county data, by sect

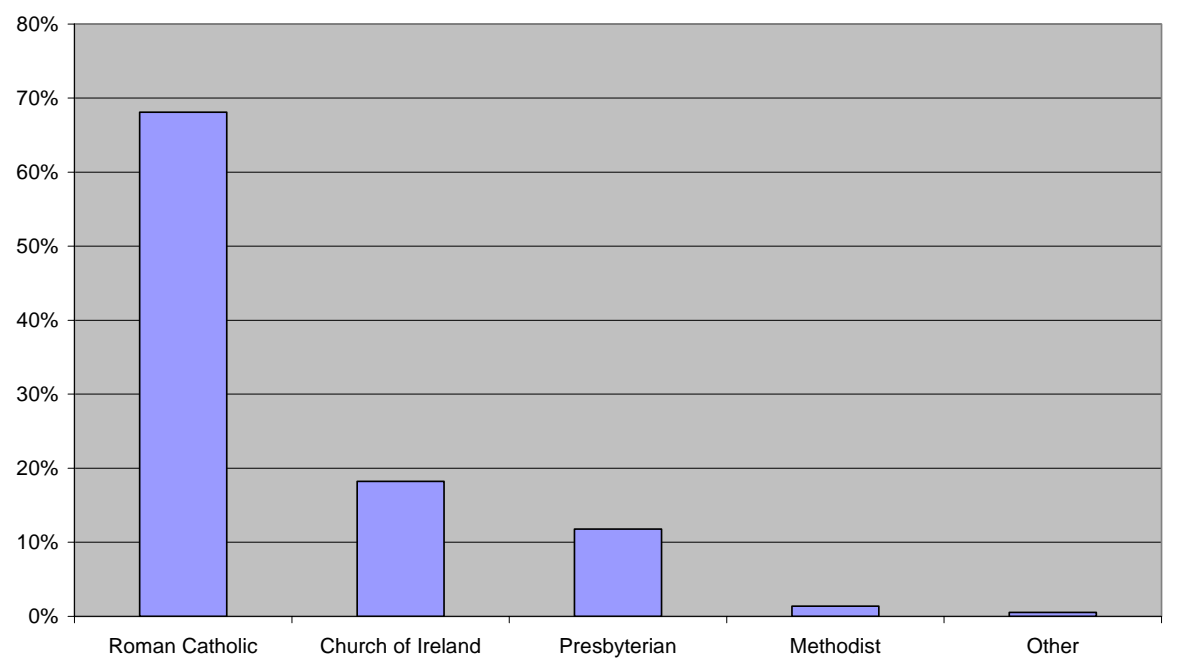

Table 9.

Religious Affiliation of $1 / 27$ th, in percent, based on extrapolation of birthplace/religion by county data, Catholic/Protestant

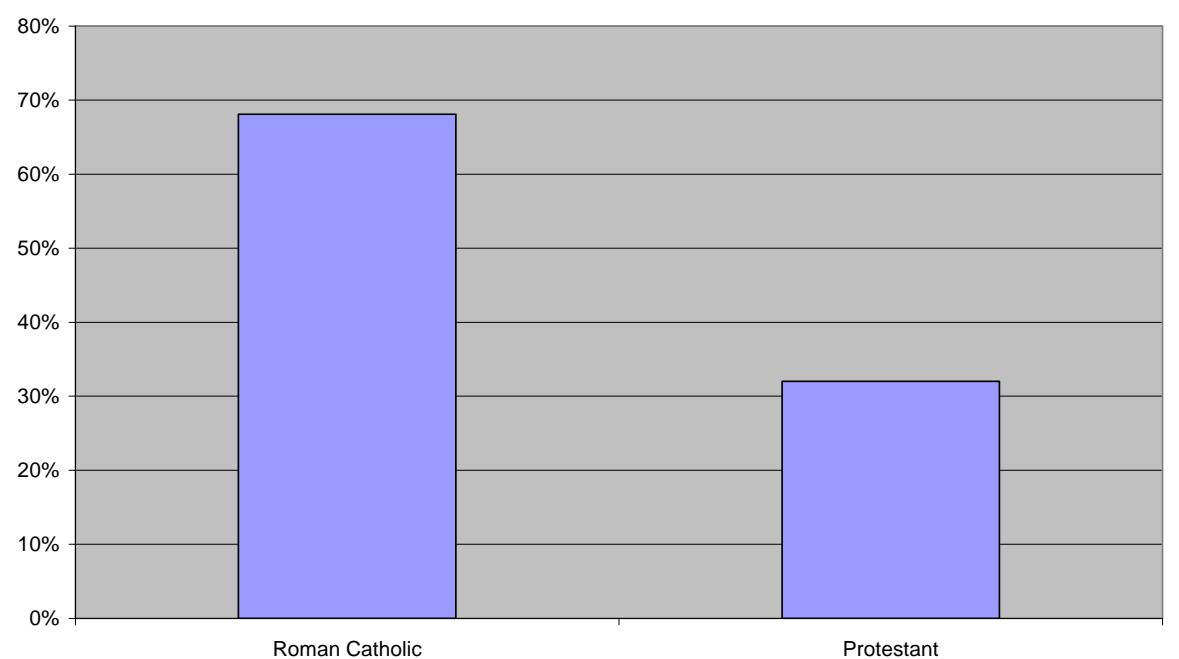

This extrapolation is based upon the available numbers due to the lack of hard data regarding actual religious affiliation in the ranks of the $1 / 27^{\text {th }}$. In support of this extrapolation, there is no evidence in the literature that suggests that there was any effort 
on the part of the Inniskillings or any other British regiment to exclude Catholic recruits in favor of Anglican or Dissenter recruits. In fact, modern authors have a frustrating hesitation to address the subject. J. A. Houlding is considered to be the expert in the make-up of the British army in the mid-eighteenth century, but he gives short shrift to religious diversity in the ranks. Houlding does mention that "none of the Catholics and only relatively small percentage of the Irish Protestants - of whom two-thirds were Presbyterian, and, therefore, suspect like the Catholics and subject to the Test Act until 1780 - could lawfully serve as private men in the Irish army.. ${ }^{97}$ But Houlding fails to explain how tens of thousands of Irishmen joined the British army prior to 1780. The only possible explanation is that those Irish recruits and the regiments that they joined winked at the official restrictions on Catholics in the army. Well before the removal of the restrictions, the British army was full of Irish Presbyterians and Catholics.

Due to the lack of hard data most modern historians are as hesitant as Houlding to address the number of Catholics in the British army, both officers and enlisted men. Richard Holmes mentions that there were many "Roman Catholics amongst the rank and file, but the army was broadly of Protestant beliefs, with a growing number of earnest Methodists." ${ }^{98}$ Sylvia Frey sums the complexities of the situation with a broad statement that, following the removal of Catholic restrictions "at the time of the American Revolution", Catholics "enlisted in numbers sufficient to fill entire regiments."99

The extrapolation of religious affiliation in the $1 / 27^{\text {th }}$ is further supported by the preceding graph, Irish Religions by Percent, which bears re-examination. The twelve percent of the population which belonged to the Anglican faith had claim to the elite

\footnotetext{
${ }^{97}$ J. A. Houlding, Fit for Service, 46.

${ }^{98}$ Richard Holmes, Redcoat, 354-355.
} 
positions in Irish society and politics. Certainly not all Anglicans held elite status, but due to their better prospects in civilian life it would be rare for many Anglicans to appear as enlisted men. Presbyterians would certainly have been well represented in the ranks of the $1 / 27^{\text {th }}$, but Presbyterian communities were the backbone of the growing textile-based middle class in Ulster, and there is no indication that Presbyterians would have been over represented in the enlisted ranks. Other religions had negligible representation in Ireland, leaving the remaining seventy-eight percent of the population to make up the enlisted ranks in the army: the Catholics.

The diverse religious backgrounds of the men of the $1 / 27^{\text {th }}$ are remarkable in that they were not a divisive issue in the battalion. The evident co-operation of men of different faiths in a stressful situation poses no small lesson to later generations of Irishmen.

\section{$\underline{\text { Literacy }}$}

In The Armies of Wellington, Phillip Haythornthwaite cites two studies suggesting that $90 \%$ of English and Scottish recruits of the Napoleonic era had at least rudimentary literacy skills. ${ }^{100}$ The Irish Census of 1841 shows that literacy rates for Irish males between the ages of sixteen and forty-five were sharply lower. ${ }^{101}$ The results from the 1841 census are the earliest available, and one can suppose that the actual rates in 1815 were proportionally worse. As with so many socially significant measures, the provinces and counties of Ireland had widely different results. In Leinster, where English influence was strongest, illiteracy averaged less than $30 \%$. The counties of Ulster, too, had long

\footnotetext{
${ }^{99}$ Sylvia Frey, The British Soldier in America, 11.

${ }^{100}$ Phillip Haythornthwaite, Armies, 50.

${ }^{101}$ Clarkson, L.A. et al., Database of Irish Historical Statistics : Literacy, 1841-1911.
} 
been under English domination, and the rate of illiteracy was also under 30\%. Ulster's only exception, as usual, was the wild hinterland of Donegal, where illiteracy marked nearly $50 \%$ of military-age men. Most of the rest of Ireland was similar to Donegal, with illiteracy rates of $50 \%$ being common, while the poverty-stricken Connaught counties of Galway and Mayo suffered a crippling $65 \%$ rate of illiteracy.

Table 10.

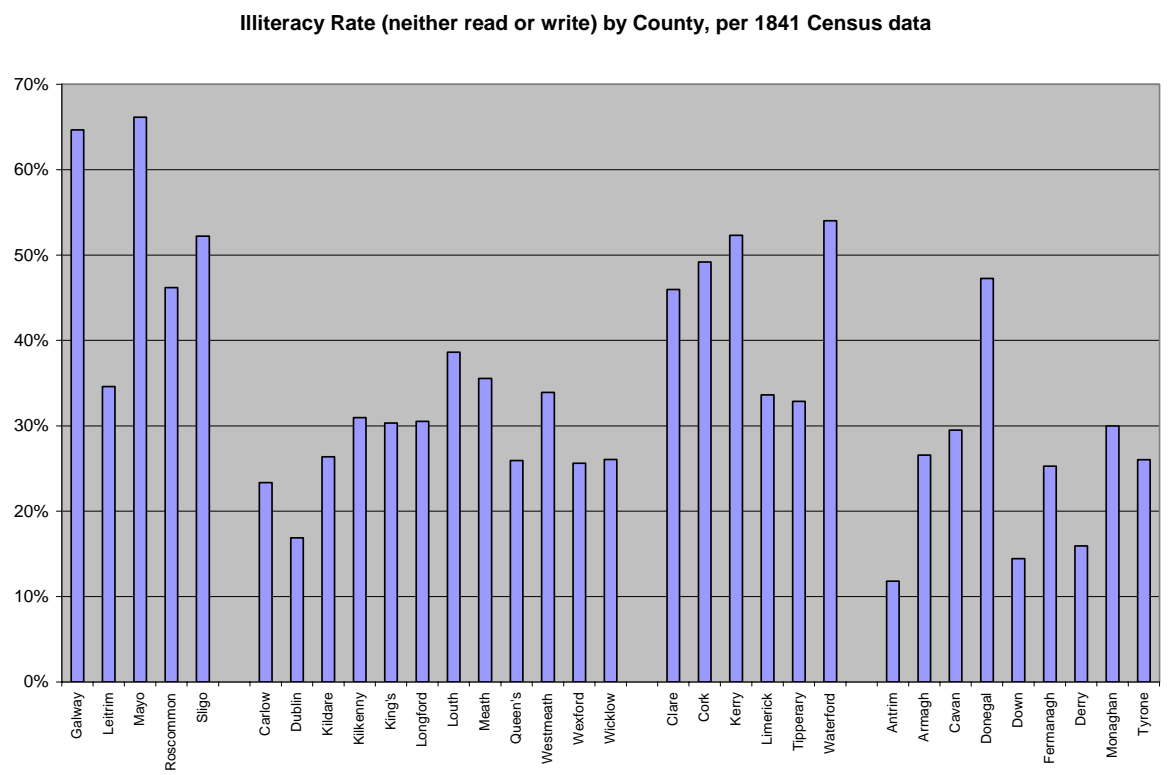

The rates of illiteracy of the men of the $1 / 27^{\text {th }}$ can be extrapolated by comparing the birthplaces of the men with the illiteracy rate of each man's county. While this extrapolation cannot be entirely accurate, it gives a good indication of how the background of the battalion's men influenced their abilities. 
Table 11.

Extrapolated Illiteracy in 1/27th, by Birthplace/Illiteracy by County

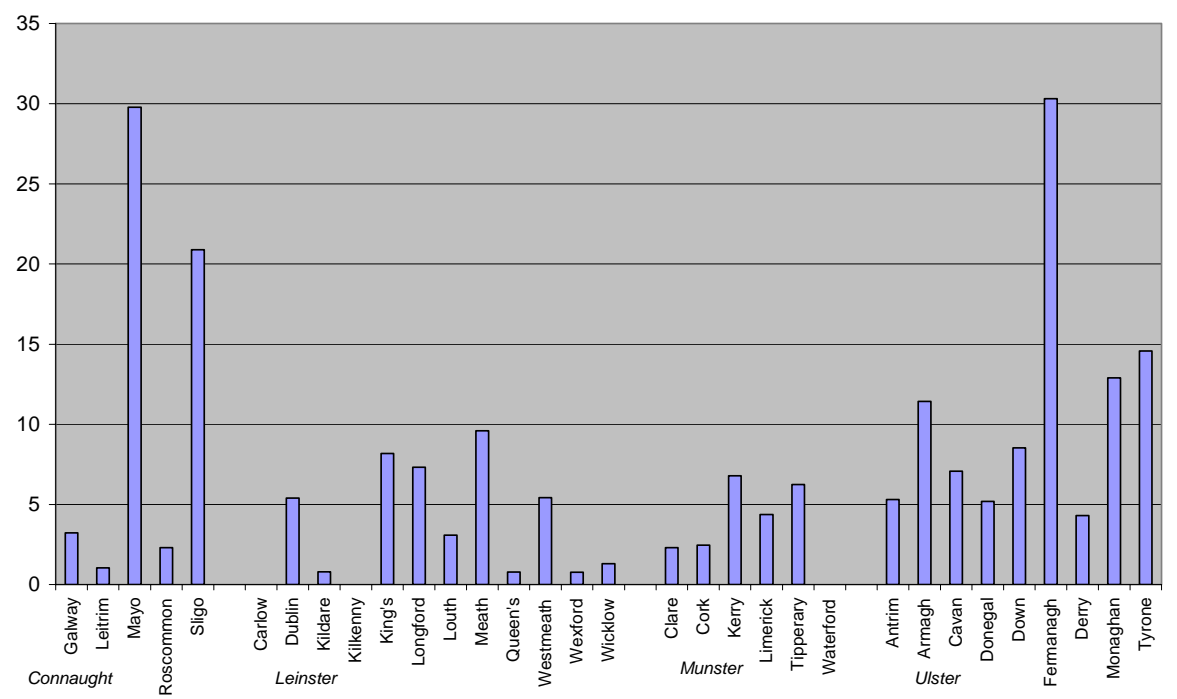

The number of illiterate men can thus be estimated to be approximately two hundred of the battalion's seven hundred men, or almost $30 \%$.

Table 12.

Illiteracy in 1/27th, Extrapolated from Birthplace/llliteracy Rate by County

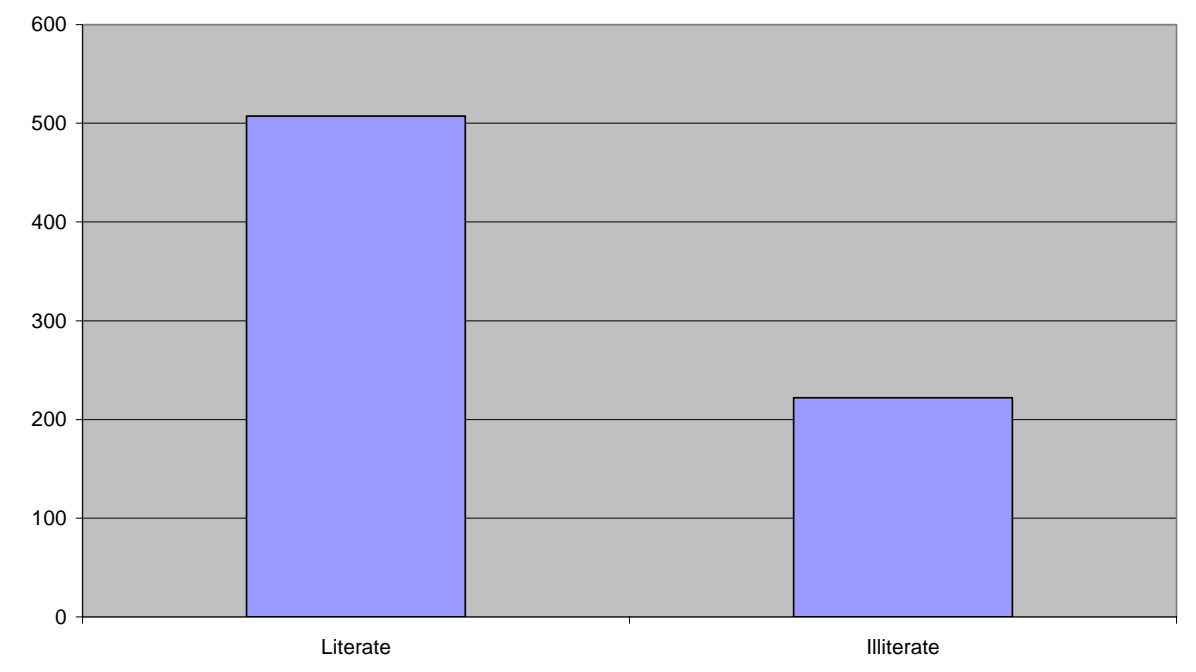


While illiteracy was not prohibitive to an army career, it limited a man's opportunities for promotion to NCO rank, let alone a commission. Further, illiteracy isolated an enlisted man; only a literate comrade could share newspapers or letters from home. Some men did learn to read and write in the army, and some units had regimental schools. The Inniskillings' rosters consulted for this thesis have a line where the name of the "School Master as Sergeant" is to be entered. Every roster bears only the word "none," so it seems that education was not a priority in the $1 / 27^{\text {th }} .102$

\section{Language; teanga}

Language is more than a form of communication. Irish language historian Tony Crowley writes that language has "roles which are linked to issues such as identity, legitimacy, proprietorship, cultural struggle, and memory." 103 The nationalistic tone that is a trademark of modern Irish is seen in a phrase taught to current students of the language: Is fearr liom Gaelige briste ná Béarla cliste ("Better bad Irish than good English"). But Crowley also argues that even though the Irish language would come to be seen as an integral part of Irish nationalism, in the late seventeenth and early eighteenth centuries that was not the case. Irish was seen as giving "a sense of nationality, based on culture, rather than nationalism, based on political cause." ${ }^{\text {104 }}$

Throughout the seventeenth and eighteenth centuries Irish was the language of many of the common people, especially Irish Catholics. In addition, many Scottish Presbyterians who populated Ulster spoke a Scottish Gaelic that was not dissimilar to Irish. While widespread, Irish was "not the language of power, commerce, or even, in

\footnotetext{
${ }^{102}$ United Kingdom war Office, $1 / 27^{\text {th }}$ Regimental rosters, 1815-1816.

${ }^{103}$ Tony Crowley, Wars of Words, 7-8.

104 ibid., 2.
} 
any important sense, religion, and it was in slow but continuous ebb."105 Most of the common people spoke both English and Irish, though in remote corners of the island some people were raised with just Irish. The west and south were the last bastions of Irish, and to this day those areas are home to the Gaeltacht, special regions designated as Irish-speaking. ${ }^{106}$ The retreat of Irish into isolated pockets is evidenced by the unique dialects that developed even in such a small nation. For example, the word tairbh (bulls) is pronounced tiriv' in Donegal, but ta'ri in Kerry. ${ }^{107}$

The use of Irish was in regression for several reasons. The most obvious reasons for the decline of Irish were the statutory limitations placed upon its use by the English. Original limitations on the use of Irish were directed only towards English settlers, whom the English Crown feared were growing too "Irish." In following years the Statutes of Kilkenny and the Penal Laws placed restrictions on the language and education directly on Irish Catholics. ${ }^{108}$ Further causes of the decline of Irish were lack of support from the Church and the economic lure of doing business with the English. By the eighteenth century many people regarded Irish as the language of the poor and the unsophisticated. ${ }^{109}$

Even with the waning numbers of Irishmen who had only Irish, during the Revolutionary and Napoleonic Wars there were men who joined the British army who knew no English. Many men would of course have been forced to learn quickly, but in Scottish and Irish regiments so many men spoke Gaelic that the learning curve was rather

\footnotetext{
${ }^{105}$ Liam de Paor, Peoples of Ireland, 176.

${ }^{106}$ Éamonn Ó Dónaill, Irish On Your Own (Chicago: Passport Books, 1997), 184.

${ }^{107}$ Heinrich Wagner, Linguistic Atlas and Survey of Irish Dialects (Dublin: Dublin Institute for Advanced Studies, 1958), 3.

${ }^{108}$ Tony Crowley, Wars of Words, 64-66.

${ }^{109}$ ibid., $72-74$.
} 
more gentle. As late as 1829 a Scottish regiment had a squad that drilled only in Gaelic. ${ }^{110}$ In 1810 Spain, an inspecting General reviewed an Irish regiment, the $88^{\text {th }}$

Foot, the Connaught Rangers. He stopped to ask Private Darby Rooney,

to whose squad he belonged. Darby Rooney understood about as much English as enabled him to get over a parade tolerably, but a conversation such as the General was about to hold with him was beyond his capacity, and he began to feel a little confused at the prospect of a tête-à-tête with his General: 'Squidha - sqoodha - cad dershe vourneen?'111 said he, turning to the orderly-sergeant, Pat Gafney, who did not himself speak the English language quite as correctly as Lindley Murray. 'Whist, ye Bostoon, ${ }^{112}$ said Gafney, 'and don't make a baste of yourself before the General." - "Why," said General Mackinnon, "I believe he don't understand me.' - 'No sir,' replied Gafney, 'he don't know what your honour manes. ${ }^{\prime 113}$

The Irish Census of 1851 was the first census to contain language data. The data for men between 20 and 40 provide the best numbers available to examine the likely languages of military-age men. It should be stressed that between 1815 and 1851 the number of Irish-only speakers dropped, so the numbers presented here are certainly too low. The linguistic backgrounds of the provinces and counties of Ireland are very evident. In the most remote parts of Connacht and Munster about ten to twenty percent men of military age spoke only Irish. In isolated Dhun na nGall, Donegal, nearly thirtyfive percent of those men had only Irish.

\footnotetext{
${ }^{110}$ Diana Henderson, Highland Soldier (Edinburgh: John Donald Publishers, Ltd., 1989), 78.

111 "What does he say, honey?" In Irish, men often address each other with such endearments.

112 "Hold your tongue, you booby."
} 
Table 13.

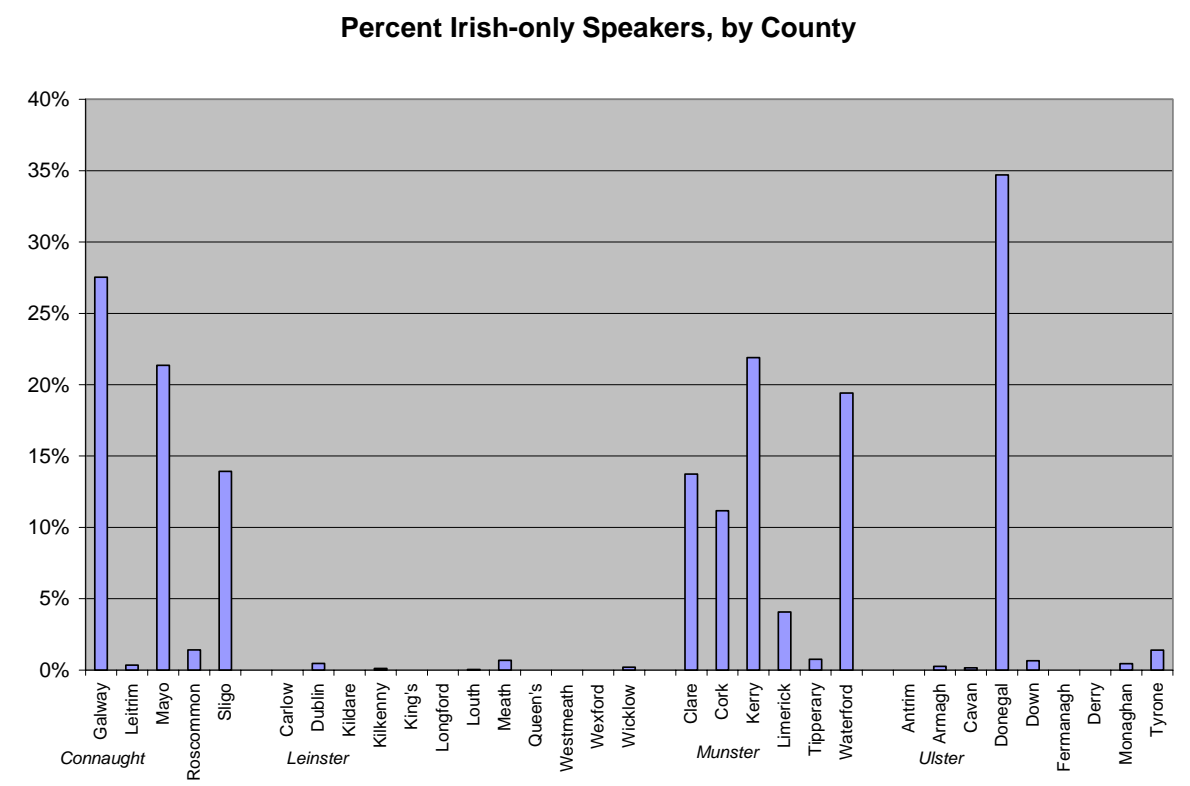

Table 14.

Extrapolated Irish-only Speakers, 1/27th

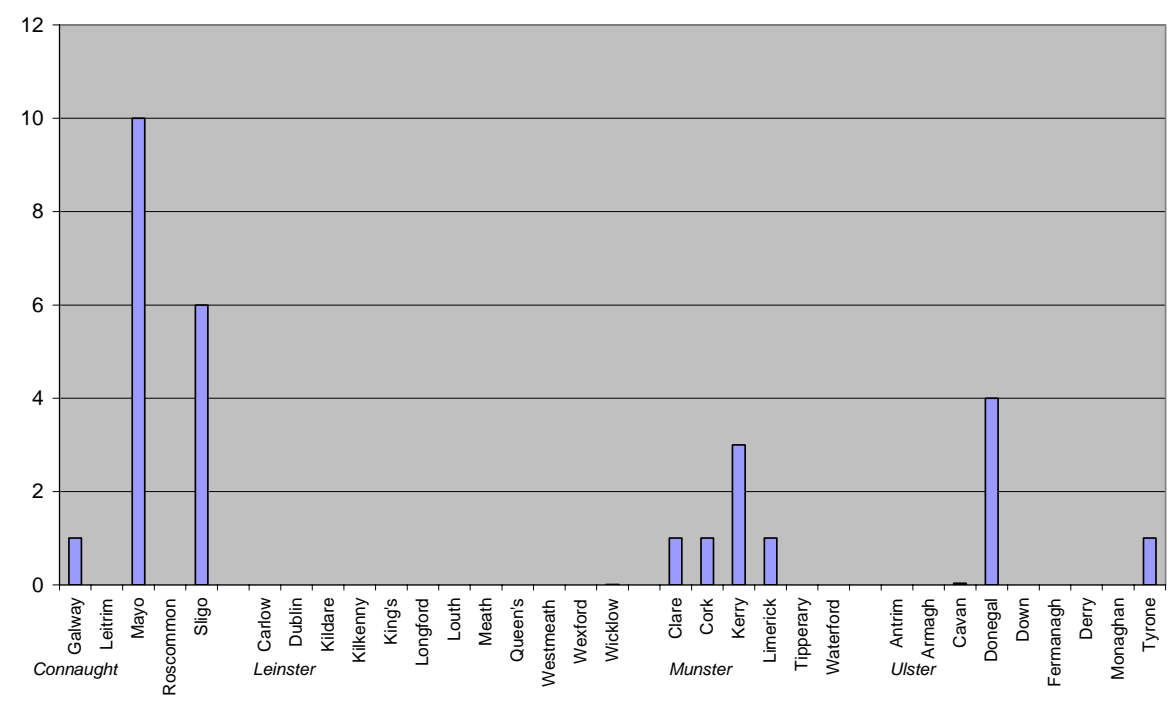

Again, the birthplaces of the men of the $1 / 27^{\text {th }}$ can be applied to the known Irish-only percentages by county to extrapolate a likely number of Irish-speakers in the ranks at

${ }^{113}$ Lieutenant William Grattan, Adventures with the Connaught Rangers; 1809-1814 (Oxford: Greenhill Books, 1989), 126. 
Waterloo. This extrapolation yields about thirty men; the actual number was likely higher.

While there is no evidence that a man who spoke only Irish was ever turned away as a recruit, such a man would certainly have had a difficult time once in the army. Only in an Irish regiment would an Irish-speaker fit in, which perhaps was a recruiting tool which only Irish regiments could offer. Recruiting sergeants who spoke Irish would certainly have had an advantage in talking to potential recruits in such counties as Galway, Kerry, and Donegal. Once in the ranks of an Irish regiment, the language constraints of an Irish-speaking soldier meant considerable isolation from the Englishspeaking army and society; his regiment would be his only home.

\section{Housing}

There are no measurements of poverty levels in the Irish censuses of the early to mid-nineteenth century. Such a measure would be of great value to this thesis, as poverty is seen as a primary driver of recruitment for the British army in Ireland. One area of the 1841 census, however, may be utilized to provide equivalent data. Housing was studied in some depth, and judging by the written comments of the census authors they felt that their work in housing was in many ways an analysis of poverty in Ireland. For example, at one point the authors observe, "that in towns, and indeed frequently in the country, several families reside in the same house. Many may, therefore, reside in a first or second class house, who, nevertheless, are living in the most wretched state as to accommodation.”114

${ }^{114}$ Clarkson, L.A. et al., Database of Irish Historical Statistics: Housing: 1821-1911. 
The census takers were instructed to separate the houses of Ireland into four categories. First Class accommodation was large, multi-room homes that contained only one family. Second Class accommodation was a smaller, less desirable house, or a First Class home that contained two to three families. Third Class accommodation was even smaller, or a Second Class house with two or three families, or a First Class house with four or five families. Fourth Class accommodation was essentially a cabin, or a Third Class house with two or three families, a Second Class house with four or five families, or a First Class house with six or more families.

As with religion, literacy, and language, the provinces and counties of Ireland had vastly different qualities of housing. Dublin had a large number of First Class homes, and was obviously the seat of wealth and power. The counties of Ulster had roughly the same number of First Class homes as the rest of Ireland, but they had a greater number of Second Class homes, pointing out the burgeoning middle class in the north.

Table 15.

Numbers of Homes, by Class, by County

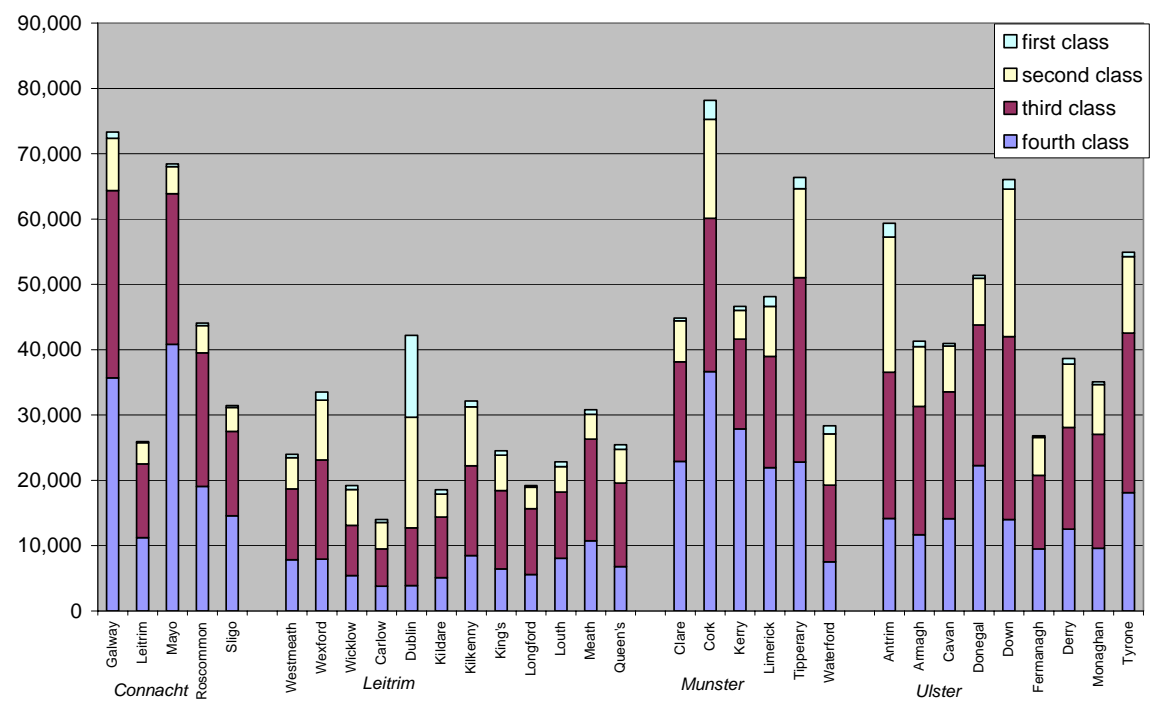


The number of Fourth Class homes in Munster and Connacht point out, once again, the poverty and isolation of those regions compared to Leitrim and Ulster.

Table 16.

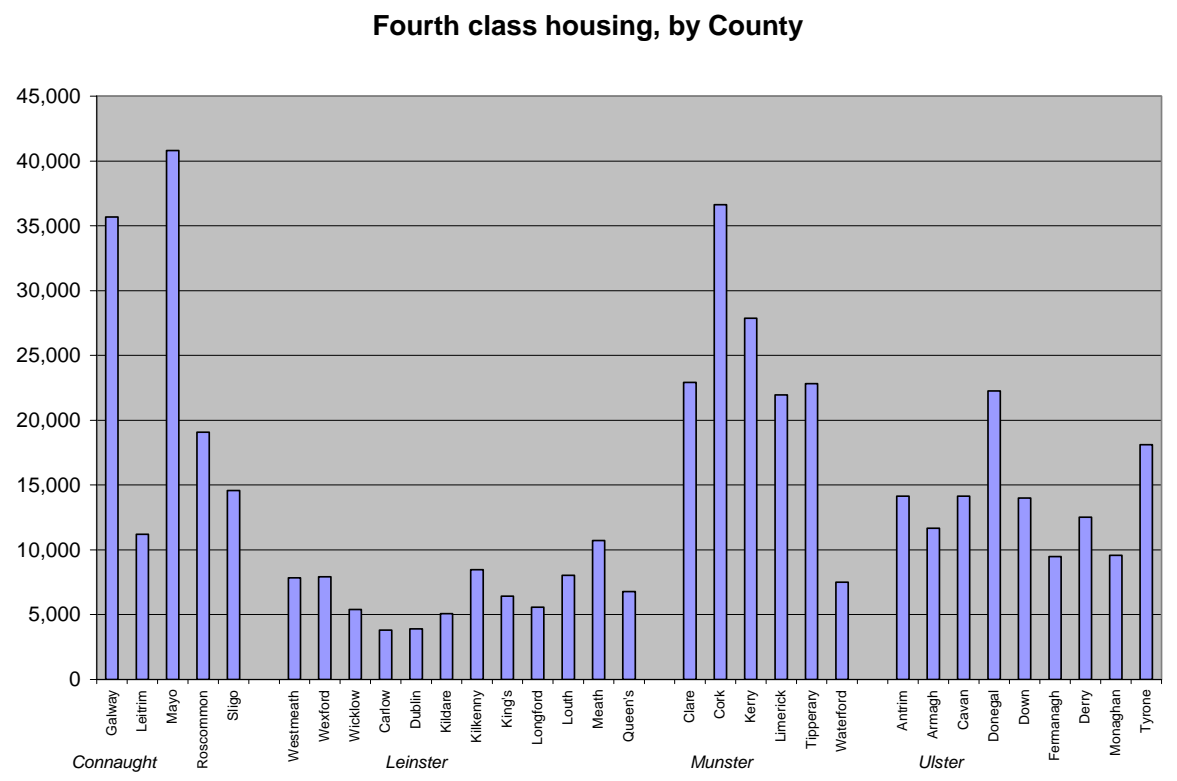

But the percentage of Fourth Class homes is a much better indicator of the overall state of the country.

Table 17.

Fourth Class Housing, in percent, by County

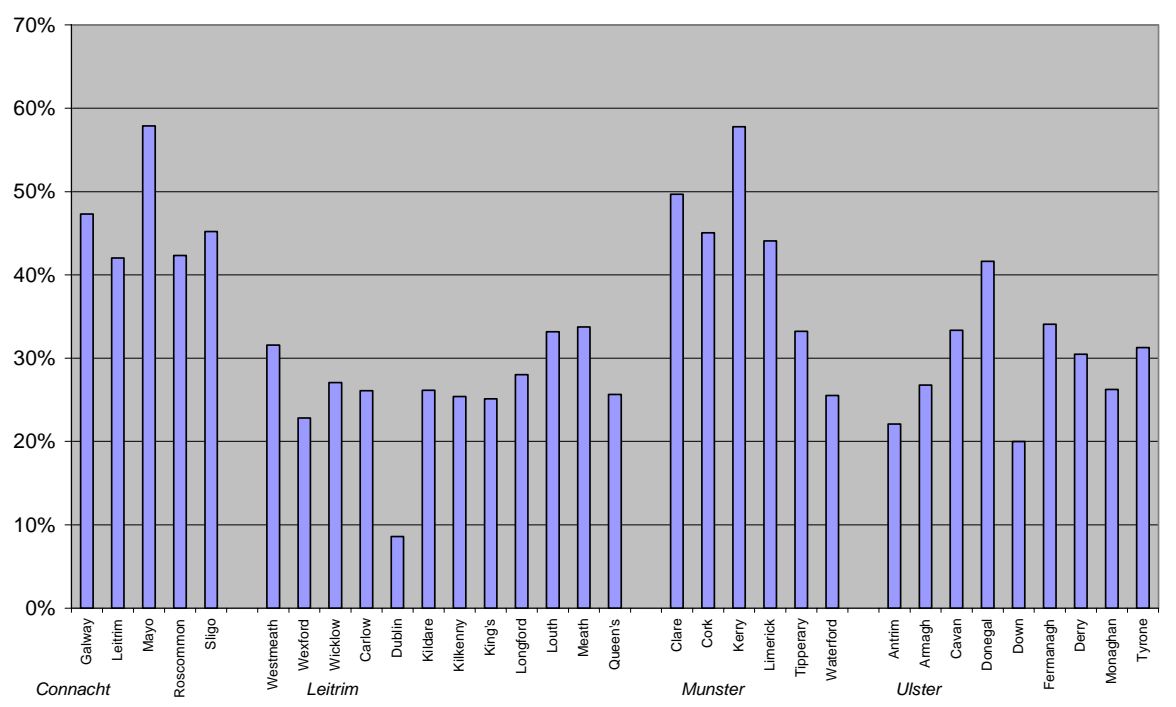


Interestingly, while Connacht and Munster reflected an average of Fourth Class housing over forty percent, the rest of Ireland still averaged about thirty percent, showing that wretched housing conditions, and hence extreme poverty, were common throughout Ireland. It is small wonder that Ireland was such a rich recruiting ground for the British army.

Records regarding birthplace, religion, literacy, language, and housing combine to fill in a large part of the background of the men of the $1 / 27^{\text {th }}$. Ascertaining the place of birth of the men of the $1 / 27^{\text {th }}$ is critical in establishing that the battalion was indeed an Irish one. Based on the knowledge of their birth, it can be safely concluded that the regiment was constituted of men from all religious backgrounds. Some of those men spoke only Irish, and some two hundred were illiterate. All the men of the $1 / 27^{\text {th }}$ were products of the impoverished Irish economy. While some of the officers may have been heirs to the wealth of the Anglican aristocracy, the enlisted men would have been products of the poverty that gripped Ireland, manifested in the wretched housing that haunted so many Irish families. The battalion was a microcosm of Ireland itself; a mixture of religion, language, literacy, and opportunity, all of which combined to make the Inniskillings a unique body of men at Waterloo. 


\section{THE MILITARY MODEL}

John Lynn's model of Combat Effectiveness, as featured in Bayonets of the

Republic, is a comprehensive attempt to quantify the many factors that affect the

behaviors of men in battle. The model is complex, and a diagram of the model's

components is useful in following the discussions below. Changes have been made to the

original Lynn model for this thesis in order to examine a battalion as opposed to Lynn's

Armee du Nord.

Model of Combat Effectiveness

\begin{tabular}{|l|}
\hline MOTIVATIONAL SYSTEM \\
Interest \\
Coercive \\
Remunerative \\
Normative \\
Self-Interest \\
Morale \\
Societal Attitudes \\
Indoctrination \\
Wartime Opinions \\
Reaction to service conditions \\
Esprit de Corps \\
Primary Group Cohesion \\
Motivation \\
Initial Motivation \\
Sustaining Motivation \\
Combat Motivation \\
Relations between officers and men \\
\hline
\end{tabular}

\begin{tabular}{|l|}
\hline MILITARY SYSTEM \\
\hline Disciplinary System \\
Tactical System \\
Weapons \\
Doctrine \\
Tactics \\
Training \\
Experience \\
Administrative System \\
Recruitment \\
Families \\
Equipment \\
Food and Drink \\
Medical Services \\
Organizational System \\
Command System \\
Promotion \\
Communications
\end{tabular}




\section{The Motivational System}

What motivates soldiers is the key question of this thesis. John Lynn organizes the complicated aspects of troop motivation into three broad areas. The first basis of motivation is interest. Interest interacts with the other elements of the motivational system: morale, group cohesion, motivation, and the relations between officers and men. Together these factors present a model of motivation that applies to an Irish battalion as well as a French army.

John Lynn has also developed a concept of motivation that encompasses three phases of motivation: Initial, Sustaining, and Combat. ${ }^{115}$ Initial motivations are those concerns that prompt a man to enlist; sustaining motivational factors are those which come from military life and tend to keep men in the ranks. Combat motivation is driven by factors entirely separate from initial and sustaining concerns; the fear of combat drives out all but the most essential motivations. While these phases are fully discussed further in this paper's section on motivation, the terms will be utilized in several of the discussions regarding interest and group cohesion.

An example of the functioning of this model is a soldier's pay. Pay qualifies as an element of interest for the soldier, as he gains benefit from it. Pay serves as motivation during the Initial and Sustaining phases, as a soldier may enlist, and stay in the army, in order to draw his pay. But pay can hardly be seen as a combat motivation; the average soldier is not worried about his next pay day in the heat of battle.

${ }^{115}$ John Lynn, Bayonets of the Republic, 35. 


\section{$\underline{\text { Interest }}$}

Interest is one of the factors that bring men into the army, keeps soldiers in the army, and in some instances can be seen as a combat motivation. Interest can be anything from which the soldier gains either physical or emotional benefit. Wellington thought that interest was a primary motivation to the men joining his army:

Some people talk of their enlisting from their fine military feeling - all stuff - no such thing. Some of our men enlist from having got bastard children - some for minor offences - many more for drink. ${ }^{116}$

Wellington's comments focused on the interests that influenced enlistment, though strong elements of interest were involved in sustaining and combat motivation as well. John Lynn cites three ways that interest is utilized by armies to leverage the behavior of its men: coercive, remunerative, and normative. ${ }^{117}$ Coercion is the use of physical punishment, or at least the threat of its use, to force obedience; self-interest is served through the soldier's avoidance of such punishment. Remunerative leverage is manifested through pay, pensions, and prizes distributed by government authority, and through plunder available on the battlefield. Normative influence impacts the soldier through psychological rewards and punishments such as praise, acceptance, or humiliation.

Coercion was very much an element of the culture of the British army of the Napoleonic era. At Waterloo the threat of coercive physical violence was omni-present. Officers and NCOs were not above using physical force to make their men obey. Captain Cavalié Mercer's battery was stationed near a square of Brunswick infantry under fire;

\footnotetext{
${ }^{116}$ Wellington, quoted in Richard Holmes, Acts of War: The Behavior of Men in Battle (New York: The Free Press, 1985), 274.
} 
they "were falling fast - the shot every moment making great gaps in their squares, which the officers and sergeants were actively employed in filling up by pushing their men together, and sometimes thumping them ere they could make them move." ${ }^{, 18}$ Another threat of physical force intended to keep infantrymen in place was to station a line of cavalry to their rear. ${ }^{119}$ Cavalry was often used to maintain order in civilian society, and could play the same role on the battlefield. ${ }^{120}$ Mounted men would have posed a serious threat to any men thinking of fleeing the ranks.

Remunerative elements of self-interest pose a fascinating aspect of the motivations of British soldiers. Pay, pensions, prize money, and plunder all prompted British soldiers to enlist, stay in the army, and then to face the stresses of combat. In British Line infantry regiments, an enlisted man's daily pay rate in 1815 was: ${ }^{121}$

$\begin{array}{ll}\text { Sergeant: } & 1 \mathrm{~s} .63 / 4 \mathrm{~d} \\ \text { Corporal: } & 1 \mathrm{~s} .21 / 4 \mathrm{~d} \\ \text { Drummer: } & 1 \mathrm{~s} .13 / 4 \mathrm{~d} . \\ \text { Private: } & 1 \mathrm{~s} .\end{array}$

The pay for the men of the Line regiments was the lowest in the British army; men in artillery, cavalry, and Guard infantry units were all paid more. For example, privates in cavalry and Guard infantry regiments were paid 2s. per day, twice the rate of the men of the Line infantry regiments.

For the men in the ranks, even the standard one shilling a day was an illusion, as stoppages in pay reduced their actual wages to nearly nothing. While quarters were provided by the regiment, "up to $6 \mathrm{~d}$. of the soldier's pay was taken for subsistence, and

\footnotetext{
117 John Lynn, Bayonets of the Republic, 24.

${ }^{118}$ Captain Cavalié Mercer, Journal, 170.

${ }^{119}$ See Captain Alexander Kennedy Clark and Lt. Colonel James Sleigh in Siborne, Letters, 73-74 and 106.

${ }^{120}$ Julius Ruff, Violence in Modern Europe, 68.

${ }^{121}$ Charles James, Regimental Companion, 39.
} 
other deductions were made for regulation uniform, medical treatment, the upkeep of Chelsea Hospital, breakages, barrack damages and the regimental agent." ${ }^{, 122}$ At this same time a civilian agricultural worker received 12 s. a week, and a skilled weaver was paid $£ 2$ 4s. 6d. for a week's labor. The average line infantryman had very little discretionary income, and while pay may have qualified as an initial or sustaining motivation it was certainly not a combat motivation.

The daily pay scale for officers of Line regiments in 1815 was as follows:

$\begin{array}{ll}\text { Lt. Colonel: } & 27 \mathrm{~s} . \\ \text { Major: } & 16 \mathrm{~s} . \\ \text { Captain: } & 10 \mathrm{~s} .6 \mathrm{~d} . \\ \text { Lieutenant: } & 6 \mathrm{~s} .6 \mathrm{~d} . \\ \text { Ensign: } & 5 \mathrm{~s} .3 \mathrm{~d} . \\ \text { Paymaster: } & 15 \mathrm{~s} . \\ \text { Adjutant: } & 8 \mathrm{~s} .6 \mathrm{~d} . \\ \text { Quartermaster: } & \text { 6s. 6d. } \\ \text { Surgeon: } & 11 \mathrm{~s} .4 \mathrm{~d} . \\ \text { Assistant Surgeon: } & 7 \mathrm{~s} .6 \mathrm{~d} .\end{array}$

Captains in line regiments were given an extra 2s. per diem if they held a higher brevet rank, while lieutenants were given an extra 1s. per diem if they had held that rank for seven years or more. As with the enlisted men, officers in other branches of the British army were paid considerably more than those in line regiments. While a lieutenant in the line infantry was paid 6s. 6d. a day, the same rank in a line cavalry regiment was paid 9s. a day, and in the fashionable Royal Horse Guards a lieutenant was paid 15s. 6d. a day.

There were no forced stoppages from an officer's pay, but there were numerous expenses inherent in a commission. All officers had to purchase their own uniforms, weapons, and horses. The greatest expense faced by the officers was the battalion mess, to which every officer was expected to contribute money to buy food, wines, furniture,

${ }^{122}$ Richard Holmes, Redcoat: The British Soldier in the Age of Horse and Musket (London: Harper Collins 
and utensils for all of the officers to use. While one officers' guide suggested limiting the monthly subscription to one week's pay for each officer, some regiments required subscriptions that tested many officer's budgets. ${ }^{123}$ Some fashionable regimental messes included fine china, crystal, and silver, and featured expensive food and wine. Some Colonels of fashionable regiments required new ensigns joining their regiment to have private annual incomes of at least $£ 200 .^{124}$

There is no way to determine the type of mess that was kept by the officers of the Inniskillings. Wealthy officers used purchase to advance through the ranks, and judging from the comparative immobility of the Inniskillings it can be assumed that they were not men of extensive means. Their mess was probably a comparatively simple and inexpensive affair. A junior officer's pay was low, and if he was the member of a fashionable regiment he may have actually have lived beyond his means. Pay was therefore not a powerful motivation for young officers; only more senior officers received a pay that allowed a more comfortable life.

Pensions were available to enlisted men of good conduct and long service. William Wheeler, for instance, a Private with the $51^{\text {st }}$ Foot at Waterloo, left the army as a Sergeant in 1828 with a pension of 1s. $10 \mathrm{~d}$., after serving nineteen years. ${ }^{125}$ Men such as Wheeler who had served at Waterloo were granted two incremental years to their service records as a reward from the government. The hope of a pension in their old age was an incentive for some forward-thinking young soldiers, and was primarily an inducement for enlistment and retention rather than combat motivation. Private James Anton of the $42^{\text {nd }}$

\footnotetext{
Publishers, 2001), 309.

${ }^{123}$ Charles James, Regimental Companion, vol. I, 194-205.

${ }^{124}$ Richard Holmes, Redcoat, 282-283.

125 Private William Wheeler, Letters, 320.
} 
Foot, the Black Watch Highlanders, wrote in his memoirs that he and a friend enlisted from the militia primarily for the pension available to line soldiers:

My friend Huntly had been previously promoted to be a corporal... and as little prospect of further advancement appeared to gratify his views, he determined to volunteer his services to the line. His remark was, "I serve at present secure of life and limb, but with no prospect of future benefit in old age, which I may attain; it is better to hazard both abroad in the regular service, than have poverty and hard labour accompanying me to a peaceful grave at home". I concurred in his opinion. ${ }^{126}$

The greatest obstacle to obtaining an army pension was living long enough to

draw it. Combat was a periodic danger for the serving soldier, but accidents and especially disease killed many soldiers before they ever saw their pension. The recruit rosters of the $27^{\text {th }}$ Foot show that many of the Waterloo veterans never reached their pensions. Private James McNully, a former farm laborer from Sligo, was "given over to Civil Power at St. Vincent, having been transported as a felon for life by General Court Martial" in 1829. ${ }^{127}$ Private Henry McManus, once a laborer in County Armagh, survived Waterloo without a scratch, only to drown in a well just a few days later. ${ }^{128}$ Private William McSourly, a native of Enniskillen, was murdered "by persons unknown" in Dublin in 1818. Private Hugh Cassidy of Belfast was wounded at Waterloo, and was promoted to Corporal in 1819. But he was later demoted back to Private and died in Grenada in 1829. The Inniskillings were posted to the West Indies in the 1820s, and the remaining records show that the deaths of many Waterloo veterans can be attributed to yellow fever and other tropical diseases encountered while serving there. ${ }^{129}$

\footnotetext{
${ }^{126}$ Private James Anton, in William Fitchett, ed., Wellington's Men: Some Soldier Autobiographies (London: George Bell \& Sons, 1900), 48.

${ }^{127}$ United Kingdom War Office, Description book, $27^{\text {th }}$ Foot.

${ }^{128}$ United Kingdom War Office, $1 / 27^{\text {th }}$ Casualty Returns, 1815.

${ }^{129}$ United Kingdom War Office, Description Book, $27^{\text {th }}$ Foot.
} 
Many of the Inniskillings' Waterloo veterans were forced out of the army by reduction before they reached their pensions. Private John Collins, who once punted boats on the River Liffey in Dublin, enlisted in 1811, served at Waterloo, and was reduced in 1818. Color Sergeant John Evans was reduced in 1824 after twelve years of service. $^{130}$

All of the men who were given their pension were discharged with the designation "unfit for service." Private Thomas Fraser of Edinburgh was free to return to Scotland when he was discharged in 1825 as being "unfit for service" with the "out pension" of only $10 \mathrm{~d}$. a day after twenty years in the $1 / 27$ th. Most men of long service were given between 10d. and 1s. per day, but Private Peter Tierney was given nothing when he was discharged in 1827 when he, too, was seen as "unfit for service" after twenty-one years. He had no record for desertion, but to be denied a pension after such long service was rare: he must have been a very unsavory character. There is only one instance in the records of the $27^{\text {th }}$ of a man being released from his service simply because he asked to be: Color Sergeant Hugh McKay was discharged at Waterford on Sept. 1, 1818, because of "His own Request," but of course he drew no pension. ${ }^{131}$ Enlisted men who lost a limb or who were completely incapacitated were eligible for pensions of up to $2 \mathrm{~s} .6 \mathrm{~d}$. a day for privates, and up to $3 \mathrm{~s} .6 \mathrm{~d}$. for sergeants. ${ }^{132}$ There was no death benefit, however, and men who died left only their back pay. When Private Michael McGee of the $2 / 27^{\text {th }}$ died at Gibraltar in 1819 he left only his back pay of $13 \mathrm{~s} .1 \mathrm{~d}$. to his widow. ${ }^{133}$ On occasion a battalion's officers would take up a subscription to help

\footnotetext{
130 ibid.

131 ibid.

${ }^{132}$ Charles James, Regimental Companion, 41.

${ }^{133}$ United Kingdom War Office, Description Book, $27^{\text {th }}$ Foot.
} 
support a deserving soldier's widow and children, but the heavy losses at suffered by both the men and officers of the $1 / 27$ th at Waterloo meant that many widows went unsupported. ${ }^{134}$ After Waterloo, however, the British government instituted a general "Waterloo Subscription" that raised $£ 518,288$ for the support of widows, orphans, and disabled veterans of the battle, though it appears that the lion's share of the money was given to officers' families. ${ }^{135}$

The pension system for British officers of the Napoleonic era was completely different than that for the enlisted men. The primary financial support for reduced, sick, or aging officers was half-pay. Officers on half-pay served as a reserve of experienced men who could be recalled in case of need. Of course many men on the half-pay list were physically incapable of returning to active service, in which case half-pay served essentially as a pension system. Officers on half-pay had to swear an oath every six months to verify that they had not taken any other employment. ${ }^{136}$

Half pay was not actually half an officer's normal pay; the actual rates were considerably less:

$\begin{array}{ll}\text { Lt. Colonel: } & \text { 8s. 6d. } \\ \text { Major: } & \text { 7s. 6d. } \\ \text { Captain: } & \text { 5s. } \\ \text { Lieutenant: } & \text { 2s. } 4 \mathrm{~d} . \\ \text { Ensign: } & 1 \mathrm{~s} .10 \mathrm{~d} . \\ \text { Adjutant: } & 2 \mathrm{~s} . \\ \text { Quartermaster: } & 2 \mathrm{~s} . \\ \text { Surgeon: } & 2 \mathrm{~s} .\end{array}$

What is most intriguing about half-pay is the percent of the original pay that each rank was allowed to maintain. For example, a Lt. Colonel's daily pay dropped from $27 \mathrm{~s}$. to 8 s.

\footnotetext{
${ }^{134}$ Charles James, Regimental Companion, 194.

${ }_{135}^{135}$ Mark Adkin, Waterloo Companion, 420.

${ }^{136}$ Charles James, Regimental Companion, 45.
} 
$6 \mathrm{~d}$.; he kept only $30 \%$ of his original pay. A Captain, however, was normally paid 10 s.

6d. per day, and on half-pay he was allowed 5 s., or $48 \%$ of his original pay. The percentages for all ranks:

Lt. Colonel: $\quad 30 \%$

Major: $\quad 44 \%$

Captain: $\quad 48 \%$

Lieutenant: $\quad 31 \%$

Ensign: $\quad 19 \%$

Adjutant: $\quad 24 \%$

Quartermaster:31\%

Surgeon: $\quad 18 \%$

While at first there seems no logical pattern in half-pay allocation, it appears that the army was anxious to retain Captains and Majors. The army obviously felt that very junior and very senior officers were not worth a large investment. This is significant in pointing out that the government was conscious of its need to retain experienced men. The army had sufficient Lt. Colonels, and had no reason to hold onto unseasoned junior officers: they needed to maintain a large number of experienced officers on the payroll in case of great need.

Assistant Surgeons did not qualify for half-pay, and Surgeons' half-pay was ridiculously low. In can be assumed that there was no shortage of inexperienced medical men, and thus the army did not worry about retaining their services. There was, however, a unique pension for Surgeons, who were to be given a pension of 5 s. per day after twenty years of good conduct. ${ }^{137}$ If there was little interest in keeping a reserve of medical men, keeping good surgeons in the ranks was a priority.

There was an annual pension granted to the widows of officers who had been killed in action. The amounts were: 


$\begin{array}{ll}\text { Lt. Colonel } & £ 80 \\ \text { Major } & £ 50 \\ \text { Captain } & £ 30 \\ \text { Lieutenant } & £ 26 \\ \text { Ensign } & £ 20 \\ \text { Quarter-master } & £ 20 \\ \text { Adjutant } & £ 20 \\ \text { Surgeon } & £ 26 \\ \text { Asst. Surgeon } & £ 20\end{array}$

As those benefits were granted only due to death in action, there were instances of desperate widows trying to prove the causes of the deaths of their husbands. For example, Lt. John Faithful Fortescue of the $1 / 27^{\text {th }}$ was badly wounded at Waterloo, being shot in the arm and through the chest. Fortescue survived his wounds, but degenerative lung damage eventually caused his death in June of 1821 . His widow was required to file sworn statements from two physicians attesting to that fact before obtaining the pension. ${ }^{138}$

A rare bonus opportunity for officers and men was the possibility of prize money. This was a motivation for combat: only men who stayed in the ranks were eligible, and men who fled battle were denounced, and denied its benefit. The prize money came from two possible sources. First, the men of a victorious army

were eligible for prize money based on the value of bullion, cash and other similar valuables which were legitimately captured and duly "condemned" as prizes. These goods were assembled and liquidated by prize agents, and the proceeds were then distributed, through regimental agents, according to a sliding scale which gave a specified number of shares to officers and soldiers according to rank. ${ }^{139}$

\footnotetext{
${ }^{137}$ Great Britain, Army, Regulations for Improving the Situation of Regimental Surgeons and Mates (London: War Office, 1796), 7-8.

${ }^{138}$ Letters from Drs. Kelly and Guthrie, in United Kingdom War Office, Pension submission, Lt. William Faithful Fortescue. WO 43/129

${ }^{139}$ Richard Holmes, Redcoat, 31.
} 
A defensive battle such as Waterloo gave fewer opportunities for the capture of enemy valuables, and this aspect of prize money was perhaps less of a combat motivation since there were few captures made by the Anglo-Allied army. A pursuing army had a better chance for capturing the enemy's valuables, and after Waterloo the Prussians pursued in lieu of the exhausted Anglo-Allied army. Napoleon's carriage was captured and looted by Prussian cavalry, though the French pay wagons were looted of a fortune in gold by fleeing Frenchmen during the chaotic night of the $18^{\text {th }} .140$

Secondly, upon the occasion of great victories such as Waterloo, Parliament sometimes authorized monetary rewards to every man present. The amount of this reward also varied by rank. After Waterloo the prizes awarded to the troops were:

$\begin{array}{lr}\text { Wellington } & £ 61,000 \\ \text { Generals } & £ 1,27510 \mathrm{~s} .10 \mathrm{~d} . \\ \text { Colonels, majors } & £ 4332 \mathrm{~s} .5 \mathrm{~d} . \\ \text { Captains } & £ 907 \mathrm{~s} .4 \mathrm{~d} . \\ \text { Subalterns } & £ 3414 \mathrm{~s} .9 \mathrm{~d} . \\ \text { Sergeants } & £ 194 \mathrm{~s} .4 \mathrm{~d} . \\ \text { Corporals, drummers, privates } & £ 211 \mathrm{~s} .4 \text {. }\end{array}$

The distribution of the funds did not come until two years after the battle, and must have caused considerable grumbling when it did come. The award was to be made to every man who had fought in the Campaign of 1815 , up to and including the comparatively bloodless capture of Paris. Many men who did not face the dangers of Waterloo were included in the prize money, and the prize roster of the Inniskillings reflects that fact. Of the seven men paid $£ 433$, only one, Brevet Major John Hare, served at Waterloo. Further, six men were paid at the captains' rate; only two, Captains Holmes and Tucker, were Waterloo veterans. ${ }^{141}$ Similar discrepancies exist in the other prize

\footnotetext{
${ }^{140}$ Mark Adkin, Waterloo Companion, 403-404.

${ }^{141}$ United Kingdom War Office, Waterloo Prize Money Disbursements, WO 164/403
} 
classes, making the prize list useless to the scholar looking for the names of the men who actually faced combat at Waterloo. The distribution of prize money is rarely mentioned in the vast literature of the battle, and while no primary source comments have been found regarding its impolitic allocation there must have been considerable resentment felt by the men who had risked their lives.

A less lofty but immediately rewarding element of remunerative influence was plunder. This type of gain was the only way in which the common soldier might reap a fortune quickly, and can be thought of as an initial, sustaining, and combat motivation. Plunder of civilians was expressly forbidden by Wellington, and many men of the British army in Spain and France lost their lives for having done so. But battlefield plunder was a long-standing tradition that even Wellington dared not attempt to regulate. Numerous memoirs of enlisted men cite the plundering of the dead and prisoners during and after Waterloo. An officer of the $5^{\text {th }}$ Division wrote of an incident that illustrates both the temptations of plunder and the physical force that officers would utilize to control their men:

I saw (the truth must be told) a greater number of our soldiers rifling the pockets of the dead, and perhaps the wounded, than I could have wished to have seen; with some exertion we got them in. Those of our own regiment the Colonel beat with the flat of his sword as long as he had breath to do so. The fellows knew they deserved it; but they observed, some one else would soon be doing the same, and why not they as well as others? ${ }^{142}$

While some officers may have abhorred the practice, many enlisted men who risked their lives for only minimal pay and pension prospects could not resist the chance of collecting a potential fortune from the packs and pockets of the dead and prisoners. The pillaging was not restricted to the enemy; the possessions of fallen comrades were 
not immune. Sergeant Edward Costello of the 95th Rifles had acquired a great sum of money from the plundering after the Battle of Vitoria, and of the action the next day he wrote,

many of our men gibing me for my wealth, saying, among other agreeable things, that if I fell they would take care of my knapsack for me. To tell the truth, I was not over-anxious to go much to the front, as I began to look on my life as of some value. ${ }^{143}$

The third elements of interest are psychological rewards and punishments such as praise, acceptance, or humiliation. A tangible token of praise, though of negligible monetary value, was the Waterloo Medal issued after the battle. Wellington requested the issuance of the medal, writing to The Duke of York,

I would likewise beg leave to suggest to your Royal Highness the expediency of giving to the non-commissioned officers and soldiers engaged in the battle of Waterloo, a medal. I am convinced it would have the best effect in the army; and, if that battle should settle our concerns, they will deserve it. ${ }^{144}$

Even the distribution of the Waterloo Medal caused ill will. Veterans who had served for years under Wellington's command in the Peninsula had never been issued a medal, and many resented "the invidious distribution of Medals" to men who had fought only a short campaign. ${ }^{145}$

Praise from the government and the Commanding General was satisfying, but praise from one's friends and immediate superiors was especially powerful. Private William Wheeler wrote home from Spain in 1813 that after he was wounded,

\footnotetext{
${ }^{142}$ Anonymous officer quoted in Rory Muir, Tactics and Experience of Battle in the Age of Napoleon (New Haven, CT.: Yale University Press, 1998), 207.

${ }^{143}$ Sgt. Edward Costello, quoted in Anthony Brett-James, The Hundred Days, 144.

${ }^{144}$ Wellington to the Duke of York, June 28, 1815, in Anthony Brett-James, Wellington at War (London: Macmillan \& Company, 1961), 314.

${ }^{145}$ Lt Charles Crowe, Memoirs, 55.
} 
I sat up with my cap on the muzzle of my firelock and cheered my comrades as they passed me. Hooker was in the throng, he smiled and said something to me as he rushed by, but I could not catch the words. Our Adjutant rode up to me and said "Corporal Wheeler I hope your wound is not severe, I shall remember your conduct, and recommend you for promotion". ${ }^{146}$

An instance of acceptance being utilized as a psychological benefit comes from a unique type of discipline used in the 51st Foot while in England in 1810. On the King's birthday the commanding officer ordered that the occasion be marked by a general pardon for every man in the regimental guardhouse. One sergeant, however, was guilty of desertion, and the Colonel felt that some additional ceremony was necessary "before he could be purged from his guilt". He ordered that during a regimental parade the regiment's colors be brought forward, unfurled, and the tops touched together to form an arch. The sergeant was ordered to pass between them and be wiped clean of his guilt. That done, the Colonel shouted,

He's half clean, he must pass under them again, let the colours touch him this time, now his crime he's blotted out for ever, he is regenerated, the new born babe is not more innocent, and, woe to the first man who ever mentions the affair to him. ${ }^{147}$

This unusual ceremony is a singular example of forgiveness and acceptance in an army that was notorious for its use of corporal punishment.

While praise and acceptance were two elements of psychological benefit, a third, less pleasant, element was humiliation. In 1809 two Irish soldiers of the $88^{\text {th }}$ Foot, the Connaught Rangers, were to be flogged for stealing a goat from Portuguese peasants.

This was a punishment within the group norms of the men, and was to be inflicted in the presence of the men's own regiment. However, General Sir Thomas Picton wished to

\footnotetext{
${ }^{146}$ Private William Wheeler, The Letters of Private Wheeler, Captain B H. Liddell Hart, ed., (Boston: Houghton Mifflin Press, 1951), 157-158.
} 
make an example of these two men and ordered that he and the entire division should witness the punishment. For the flogging to be carried out in front of the commanding General and witnesses from outside the regiment was deemed to be a deliberate effort at humiliation by the men who were to be flogged and the men and officers of the $88^{\text {th }} .48$

While soldiers would have tried to avoid the physical pain of flogging, the threat of humiliation would have been further inducement to adhere to the dictates of army rules. There was, however, a danger in humiliating men. The fear of humiliation was a tool; to actually humiliate a soldier was to diminish him in his own eyes and the eyes of his fellow soldiers. A soldier who had been disgraced was no longer a good soldier; misbehavior, discontent, and desertion were the by-products of humiliation.

Interest was a vital component of the motivations of the Inniskillings at Waterloo. There were tangible rewards for joining the army, staying in it, and fighting its battles. Pay, pensions, prize money, and plunder were all inducements to service. Psychological benefits also played a role; praise and acceptance were sought-after rewards, while humiliation was a consequence to be avoided.

$\underline{\text { Morale }}$

A topic like morale is the bane of any historian intent on quantifying the battlefield experience. Morale is a feeling; an individual and group motivation that defies definition, let alone measure. Its importance is undeniable; "Napoleon was always aware of the vital importance of morale in warfare, and another of his best-known maxims declared that in war, the moral is to the physical as three is to one."149

\footnotetext{
147 ibid., 35-36.

${ }^{148}$ Lt. William Grattan, Adventures, 18.

${ }^{149}$ David Chandler, Campaigns of Napoleon, 155.
} 
The best definition of army morale comes from S. L. A. Marshall, who, while perhaps not a great scholar, was an exceptionally intelligent, introspective soldier:

Morale is the thinking of an army. It is the whole complex body of an army's thought: The way it feels about their cause and their politics as compared with other causes and other politics. The way that it feels about its friends and allies, as well as its enemies. About its commanders and goldbricks. About food and shelter. Duty and leisure. Payday and sex. Militarism and civilianism. Freedom and slavery. Work and want. Weapons and comradeship. Bunk fatigue and drill. Discipline and disorder. Life and death. God and the devil. ${ }^{150}$

The genius of Marshall's definition of morale is in weaving morale into the fabric of military life; how men feel about hundreds of diverse things will impact their ability and desire to withstand combat. Many of the elements of morale raised by Marshall are addressed throughout this paper.

While Marshall's definition of morale is useful, it is so broad as to defy exploration. Both Gerald Linderman and James McPherson utilize powerful tools in their exploration of the motivations of Civil war soldiers, but their work concentrates on individual morale. ${ }^{151}$ The many aspects of individual morale are discussed throughout this paper, such as courage, experience, confidence in leadership, food and drink, and religion. An analysis of group morale is the goal of this section. The template offered by John Lynn in Bayonets of the Republic provides a measure of army morale that has "five categories: (1) basic societal and group attitudes, (2) opinions and codes from army indoctrination, (3) wartime opinions, (4) reactions to service conditions, and (5) esprit de

\footnotetext{
${ }^{150}$ S. L. A. Marshall, Men Against Fire, 158.

${ }^{151}$ Gerald Linderman, Embattled Courage: The Experience of Combat in the American Civil War (New York: The Free Press, 1987), and James McPherson, For Cause and Comrades: Why Men Fought in the Civil War (Oxford: Oxford University Press, 1997).
} 
corps." ${ }^{152}$ Though Lynn's model was developed for use on the first great French Republican army its emphasis translates well to the $1 / 27^{\text {th }}$.

The basic societal and group attitudes of the Inniskillings were perceptively different from every other British unit at Waterloo. The essential difference was that the $1 / 27^{\text {th }}$ was almost completely Irish in composition. Historians agree that British army units of the Napoleonic Wars consisted of a mix of English, Scottish, Welsh, and Irish soldiers. ${ }^{153}$ Of the twenty-two British unit rosters consulted for this thesis, only one, the Royal Dragoon Guards, bore no surnames of Irish origin. ${ }^{154}$

The issue of "Irishness" is a valid one; there was a discernable difference in the behavior exhibited by Irish men at Waterloo, and there was a marked awareness of nationality within the British army of the era. One difference in behavior of the Irish troops at Waterloo was their evident refusal to bear pain in the stoic manner exhibited by the English and French. Captain Cavalié Mercer walked the battlefield the morning after the battle, and near the Charleroi road he came across,

two Irish light-infantry men sending forth such howlings and wailings, and oaths and execrations, as were shocking to hear. One of them had his leg shot off, and the other a thigh smashed by a cannon-shot. They were certainly pitiable objects, but their vehement exclamations, etc., were so strongly contrasted with the quiet resolute bearing of hundreds, both English and French, around them that it blunted one's feelings considerably. ${ }^{155}$

Mercer was not hesitant to write of his disdain for the Irish; on the march to Paris he came across the Inniskillings Dragoons, whom he referred to as "rollicking Paddies".

\footnotetext{
${ }^{152}$ John Lynn, Bayonets of the Republic, 26.

${ }^{153}$ See Haythornthwaite, Armies, 75-79, and Holmes, Redcoat, 55-57.

${ }^{154}$ Michael Mann, And On They Rode: The King's Dragoon Guards at Waterloo (Salisbury: Southern Press, 1984), Appendix I.

${ }^{155}$ Captain Cavalié Mercer, Journal, 186.
} 
Mercer also characterized Catholicism as "childish mummery" and Irish women as coarse and vulgar. ${ }^{156}$

If some Englishmen disliked the Irish, the distinguished Captain George Napier was fond of them. One of the most poignant moments of his military service was when he lay wounded in a hospital in Spain, and a "drunken Irish rogue" from his company named Private John Dunn walked seven miles to visit him. Napier learned that Dunn's brother had been killed at his side in the same action in which Napier had been wounded, and then noticed that Dunn's arm was bandaged. Dunn replied,

why sure its nothing, only me arrum was cut off a few hours ago below the elbow joint, and I couldn't come till the anguish was over a bit. But now I'm here, and thank God your arrum is not cut off, for its might cruel work; by Jasus, I'd rather be shot twinty times. ${ }^{157}$

But whether loved or hated, the key was that the Irish were different. The rest of the army viewed them so, and they viewed themselves that way. When Irish regiments passed each other they cheered themselves hoarse: "The $88^{\text {th }}$ Connaught Rangers gave a wild Irish screech (I know no better word) when they saw their fellow countrymen in the $8^{\text {th }}$ Royal Irish Hussars and they played 'Garry Owen' with all their might.",158

Throughout modern history oppressed minorities have been formed into military units that served their masters with distinction. The Gurkhas have long served the British; Japanese-American and African-American units served in the United States Army during the Second World War with distinction. A convincing explanation for this seeming paradox comes from Erich Fromm, who argues that the self image of a group of oppressed individuals can be manipulated to a narcissistic level.

\footnotetext{
${ }^{156}$ ibid., 199, 24, 15.

${ }^{157}$ Captain George Napier, Passages in the Early Military Life of General Sir George T. Napier (London, John Murray, 1884), 193.
} 
Group narcissism has important function. In the first place, it furthers the solidarity and cohesion of the group, and makes manipulation easier by appealing to narcissistic prejudices. Secondly, it is extremely important as an element giving satisfaction to the members of the group and particularly to those who have few other reasons to feel proud and worthwhile. ${ }^{159}$

The $27^{\text {th }}$ Foot was one of the few regiments in the British army to be designated to be of Irish origin, and more than $90 \%$ of its members were indeed Irish. They shared their nationality, and they shared a heritage of economic disadvantage, sectarian unrest, and factional violence. The Inniskillings managed to turn the potentially negative influences of national and social origin into an additional degree of cohesion that served them well at Waterloo. While perhaps some men were drawn to enlist and remain in the $27^{\text {th }}$ Foot because it was an Irish regiment, in the end the social and national unity of the Inniskillings was a combat motivation. The Inniskillings were a cohesive group, and stayed together through the worst that combat had to offer.

The indoctrination of opinions and codes into a nation's soldiers is one of the primary functions of an army. To turn free-thinking civilians into loyal obedient soldiers has been the duty of drill sergeants since time immemorial. Some recruits were more malleable than others; a sergeant of the $28^{\text {th }}$ Foot wrote,

There are no men so good soldiers as the man who comes from the plough. We would never take a weaver while they were there. Townsmen require all the means in the power of their officers . . . to teach then that subordination is the first duty of the profession into which they have entered. ${ }^{160}$

The indoctrination of Irish soldiers would have been especially challenging, as "the ambivalent position of Irish soldiers, so many of them Roman Catholics in a Protestant

\footnotetext{
${ }^{158}$ Fanny Duberly, quoted in Richard Holmes, Redcoat, 62.

${ }^{159}$ Erich Fromm, Anatomy of Human Destructiveness (New York: Holt, Rinehart, and Winston, 1973), 204.

${ }^{160}$ Sergeant Harry Hopkins quoted in Richard Holmes, Redcoat, 56.
} 
army, and loyal servants of a state against which their countrymen periodically rebelled, was not lost on leaders and comrades alike."161

The history of oppression of much of the population of Ireland did not prevent Irish recruits from quickly adopting the role of British soldiers. When Irish nationalists tried to turn members of the Irish militia to join the Rebellion of 1798, they succeeded with only a handful of men. The Irish militia was similar to the line regiments in that the officers were primarily Protestant and the rank and file was mostly Catholic. In the Rebellion of 1798 the Irish Militia proved themselves to be ill disciplined and badly led, but loyal. In 1848 a Republican newspaper complained that service in the British army seemed "to anglicize the Irish soldier, and make him prefer the tyrant of Ireland to Ireland's self."162

Another aspect of morale was the attitude of the civilian population toward the war and the military. During the Napoleonic Wars public opinion in England was overwhelmingly in support of the Crown and Britain's war effort. While steep population growth and revolutionary idealism had brought down the monarchy and the old aristocracy of France, in Britain "challenge to the prevailing governmental regime became hard to distinguish from treason once war against France had been joined."163 One of the reasons for that support was that the wars were good for some aspects of the British economy. The wars employed much of Britain's excess population through service in the army or navy, or through employment in the new commercial endeavors that were forced upon Britain when France closed the European markets to British goods.

\footnotetext{
${ }^{161}$ Richard Holmes, Redcoat, 64.

${ }^{162}$ The Nation, quoted in Peter Karstens, "Irish Soldiers in the British Army, 1792-1922: Suborned or Subordinate?" in Peter Karstens, ed., Motivating Soldiers: Morale or Mutiny (New York: Garland Publishing, 1998), pp. 47-80.
} 
In Ireland excess population was alleviated by emigration from Ulster and a change to tillage agriculture in Munster. The switch from grazing to tillage in Munster provided at least a subsistence living for more of the Irish peasantry, and substantial additional income for their landlords. ${ }^{164}$

Beyond the relative economic and social stability that Britain experienced during the war, the population of England feared invasion by the French, and loathed Napoleon with an unprecedented passion. The popular press played upon those fears and portrayed Napoleon in text and cartoons that alternatively demonized and ridiculed the "Corsican Ogre.” In Ireland that fear of France was much less prevalent. Many of the oppressed Irish prayed for the French to come and deliver them from the English, as they had come in the abortive invasion attempts in 1796 and $1798 .{ }^{165}$

How a nation feels about a war can often be determined by the welcome that its soldiers receive when they return home. British troops returning home from Waterloo found a very supportive environment. The people of Rye, who perhaps understood a soldier's motivation more than a modern historian, raised a subscription to buy every Waterloo veteran that passed through town a pint of stout. The townspeople came out to welcome the $51^{\text {st }}$ Foot, and "as a matter of course a general fuddle was the consequence." 166 The welcome received by the $3^{\text {rd }}$ Battalion of the 27 th upon their return to Ireland was much more muted. After a series of "wet and dreary marches" across the whole of Ireland there is no mention of a welcome until they reached their barracks in

\footnotetext{
${ }^{163}$ William H. McNeill, The Pursuit of Power (Chicago: University of Chicago Press, 1982), 207.

164 ibid., 210-211.

${ }^{165}$ See Marianne Elliott, Partners in Revolutions, 16, and Thomas Pakenham, The Year of Liberty, 298332.

${ }^{166}$ Private William Wheeler, Letters, 229.
} 
Enniskillen, and even that homecoming was subdued. ${ }^{167}$ The war may have given military employment to a growing population of Irish men, but many of those army careers ended with graves in Spain, America, Belgium, and the West Indies, with no corresponding benefit for most of the people of Ireland.

How soldiers reacted to service conditions was also an important aspect of morale. Private William Wheeler wrote, "respecting Privations, soldiers on service must expect them and bare with them." 168 Several primary sources mention that Irish recruits were especially accepting of privation, as the poverty of their civilian lives gave them a special toughness. The French who came to Ireland in 1798 marveled at the euphoria evident in the Irish peasants who rallied to their colors when given standard French army rations and shoes. ${ }^{169}$ A further example comes from the memoirs of Lieutenant Grattan of another regiment raised in Ireland, the 88th Foot, during the terrible retreat from Madrid during the Peninsular war. The army was starving, cold, and demoralized, but the "Connaught Rangers" never lost their gaiety. Without shoes they fancied themselves "at home," and there were few, I believe, who would not have wished themselves there in reality. Without food they were nearly at home, and without a good coat to their backs equally so! $!^{170}$

On another occasion Grattan commented:

if it comes to a hard tug, and that we had neither rations nor shoes, then, indeed, the Connaught Rangers would be in their element, and outmarch almost any battalion in the service; and for this plain reason, that scarcely one of them wore many pairs of shoes prior to the date of his enlistment, and as to the rations (the most part of them at all events), a dozen times had been in all probability the outside of their acquaintance with such delicacies. ${ }^{171}$

\footnotetext{
${ }^{167}$ Lieutenant Charles Crowe, Memoirs, 68

${ }^{168}$ Private William Wheeler, Letters, 231.

${ }^{169}$ Archbishop Joseph Stock, A Narrative of What Passed at Killala During the French Invasion of 1798 (Dublin: DuFour Editions, 1982), 18-19.

${ }^{170}$ Lieutenant William Grattan, Adventures, 293.

${ }^{171}$ ibid., 85
} 
While the Irish soldier may have had as great an adjustment to the discipline and drill of army life as a Scottish or English soldier, the comparative poverty of the average Irish recruit steeled him to the hunger, cold, and exhaustion that were inherent conditions of army life in the early $19^{\text {th }}$ century.

Esprit de corps is another aspect of morale that is difficult for the historian to quantify. The concept of esprit de corps is perhaps best captured through one of its iconic manifestations: the role of the regimental color, which stood as an icon of group morale at Waterloo. Most infantry battalions of the Napoleonic era carried one or more distinctive flags in the field. In action the standards served a practical function, in providing a recognizable rallying point in the smoke and confusion of battle. Large flags could communicate a unit's nationality and regimental distinctions at a considerable distance.

But in all armies of the day the regimental colors carried a moral value that far surpassed their functional uses. In the British army "colours were consecrated before being presented by a member of the royal family or other distinguished individual, and were regarded as the very soul of the regiment's honour." ${ }^{, 172}$ For a unit to lose its colors was a mark of great shame to the men carrying it and the unit as a whole. To capture an enemy standard was a great honor; Captain Alexander Clark Kennedy of the $1^{\text {st }}$ Dragoons, the Royals, seized a French Eagle color at Waterloo. He made certain that the credit was his alone, crying out on two occasions "it belongs to me" to ensure that he, not

\footnotetext{
${ }^{172}$ Richard Holmes, Redcoat, 211.
} 
the other hundreds of men of that regiment, bore the glory. ${ }^{173}$ Kennedy was to end his career as a Lt. General, A.D.C. to the Queen, K.C.B. and K.H. ${ }^{174}$

British line infantry battalions carried two colors, each at least six feet square. The King's Colour was carried by every battalion, and was a Union flag with the regimental number or badge in the center. The Regimental Colour was in the regiment's facing color with the regimental number or badge in the center, with a small Union flag in the canton. For the Inniskillings, the Regimental Colour was buff, and the central badge contained a white castle with three turrets on a blue field, with the name Inniskilling over it. ${ }^{175}$

The battalion colors were carried by the two most junior of the battalion's officers. These two officers were posted in the center of the battalion with four sergeants to cover them. The two color bearers were often very young men who took the honor of defending the colors very seriously. At the Battle of Quatre Bras, fought two days before Waterloo, the center of the $1 / 44^{\text {th }}$ was attacked by veteran French lancers:

One of these old grey-headed devils dashed through our centre, sending his lance in at the left eye of the Senior Ensign, James Christie, down through his face until it went through his tongue and under his jaw, (the Lancer) expecting to carry off the Colours. But no, he (Ensign Christie) dashed the Colours down and fell above them. The fellow was shot a few yards in front of the Regiment. ${ }^{176}$

While the men of a battalion fought hard to preserve their colors, they were not insensible of the danger. The $1 / 40^{\text {th }}$ Foot was brigaded with the Inniskillings at Waterloo, and Sergeant William Lawrence of that regiment left an interesting account regarding the "honor" of being posted to the colors during the battle:

\footnotetext{
${ }^{173}$ Captain Alexander Clark Kennedy, in Siborne, Letters, 75-76.

${ }^{174}$ Charles Dalton, Waterloo Roll Call (New York: Hippocrene Books, 1971), 56.

175 Terence Wise, Flags of the Napoleonic Wars (II) (London: Osprey Publishing, 1978), 6-7.

${ }^{176}$ Lt. Alexander Riddick, 1/44 ${ }^{\text {th }}$, in Siborne, Letters, 380.
} 
About four o'clock I was ordered to the Colours. This although I was used to warfare as much as any, it was a job I did not at all like; but still I went as boldly to work as I could. There had been before me that day fourteen sergeants already killed and wounded while in charge of these Colours, with officers in proportion, and the staff and Colours were almost cut to pieces. ${ }^{177}$

It should be noted that the $1 / 40^{\text {th }}$ was deployed to the rear of the Inniskillings, and lost only 189 men compared to the 463 lost by the Inniskillings. ${ }^{178}$ The fighting around the Inniskilling's colors must have been truly horrendous. The casualties of the $1 / 27^{\text {th }}$ bear testimony. The two color bearers were Ensigns Samuel Ireland and John Ditmas; Ireland was killed during the battle, and Ditmas was wounded, as were the other three Ensigns of the battalion who took their place at the colors. Of the thirty-four sergeants and color sergeants in the ranks of the Inniskillings, twenty-three, or sixty-eight percent, fell during the battle.

British soldiers died defending the symbol of their group identity, their esprit de corps. They did not die as fanatics; they knew the risks of standing by the colors, and did so willingly. All the elements of their military lives combined to prompt them to do their duty as they knew it. Morale is difficult to define, difficult to measure, but undeniably evident in the actions of both officers and enlisted men of the Inniskillings at Waterloo.

\section{Primary Group Cohesion}

Modern scholars of men in combat recognize the myriad psychological factors that influence the behavior of men in battle. One of the most powerful of these factors is primary group cohesion. Group cohesion has physical and emotional aspects, each playing upon the other. Throughout history the physical proximity of a soldier's

\footnotetext{
${ }^{177}$ Sergeant William Lawrence, $1 / 40^{\text {th }}$, quoted in Adkins, Waterloo Companion, 359.

${ }^{178}$ Scott Bowden, Armies at Waterloo, 253.
} 
comrades has been a key part of a military unit's cohesion. As early as ancient Greece the tactics

of the ancient phalanx were ideally suited to ideas of loyalty and friendship; fighting together in column, rather than spread along a line, drew all in close proximity with each other: a man's moment of bravery or lapse into cowardice was manifest to all who fought in rows and files to his rear, front, and side. ${ }^{179}$

One of the first modern writers to explore the nature and role of group cohesion during the Second World War was S. L. A. Marshall. Since the First World War weapons and war had evolved to the extent that men were scattered across the battlefield in a way unknown in earlier wars. But even when spread many feet apart, Marshall argued that through communication men could establish a bond that made the individual the part of a cogent unit:

Where formerly each man was three-quarters vulnerable in tactical fact, he is now protected on flanks and rear. From the physical uniting of the position comes its moral solidarity. The means establishes the will. ${ }^{180}$

During the Revolutionary and Napoleonic Wars the men in the ranks maintained a physical contact not dissimilar to that of the ancient Greeks. Maintaining that physical contact within the ranks was vitally important to a unit's cohesion in a substantive sense, but also in a moral sense. Few tacticians of the day openly discussed the psychological impact of tactics. Napoleonic tactics were primarily intended to place men where they would be most effective in combat, while the soldiers' motivations were believed to be derived of the mono-dimensional virtue of "courage.", 181

\footnotetext{
${ }^{179}$ Victor Davis Hanson, The Western Way of War (Oxford: Oxford University press, 1989), 119.

${ }^{180}$ S. L. A. Marshall, Men Against Fire, 127.

${ }^{181}$ Brent Nosworthy, With Musket, Cannon, and Sword: Battle Tactics of Napoleon and His Enemies (New York: Sarpedon, 1996), 35-48.
} 
While Napoleonic tacticians did not refer to group cohesion per se, they did know that men performed better when they were in the ranks with their usual comrades. It was believed that officers "should be shifted as seldom as possible," 182 and a similar policy was evident amongst British enlisted men when a party of recruits joined a veteran battalion in Spain:

The men were distributed through the regiment. One of them was ordered to fall in on my right, this separated me from a man who had stood next to me in many fights and was not relished by either of us. The man saw we did not wish to be separated, offered to change places, this I accepted and he took my left. ${ }^{183}$

The square formation adopted by the Inniskillings beside the Charleroi road was nearly as dense as the ancient phalanx, and gave equivalent proximity and security. The ranks were four men deep, and only a few feet behind each rank of men was another rank covering the rear and flanks. Captain Hare, commanding the battalion, was not more than forty yards from every man in the battalion. Further, the large number of wounded men who were dragged into the center of the square made the position essentially a hospital; men felt the supporting presence of their comrades, but they also felt the presence of wounded comrades who needed their protection.

Beyond the physical aspects of group cohesion were the purely emotional aspects. Most modern students of war acknowledge that comradeship is the prime motivator of men in combat. Richard Holmes says that "the full flowering of group cohesion is to be seen in the regiment, whose corporate identity is often reinforced by distinctive uniforms and insignia, its roots lie deeply in the smallest of military groups." ${ }^{184}$ The Inniskillings had distinctive buff collars and cuffs, their cap badges bore the turreted castle of

\footnotetext{
${ }^{182}$ Charles James, Regimental Companion, vol .I, 155.

${ }^{183}$ Private William Wheeler, Letters, 142.
} 
Enniskillen, and their Regimental Color bore the battle honors of past victories. Beyond the outward trappings of group cohesion, the men of the $1 / 27^{\text {th }}$ shared nationality and experiences that pulled them together. Small groups of comrades, many of whom had been together for years, served as the basic element of group cohesion. As will be seen later in this thesis, in the $1 / 27^{\text {th }}$ of 1815 the majority of the men had from five to fifteen years of experience. Those men would have built close relationships, forged in combat and shared suffering.

In his doctoral dissertation, "The Spirit of the Corps," Scott Hendrix argues that the British army of the mid-eighteenth century did not recognize or utilize the power of small group cohesion. Hendrix argues that British tactical doctrine could scatter the officers across different companies, so "a soldier might find himself going into battle under a strange officer, and an officer could find himself leading relative strangers into battle." ${ }^{185}$ In support of this conclusion Hendrix cites J. A. Houlding's masterful Fit for Service, but a careful reading of Houlding shows that by 1750 the British army had largely abandoned the system cited by Hendrix. The new system was considered a great improvement, as "not breaking up the companies improved the morale of the men, since they went into action in their accustomed units, among officers and men with whom they were well acquainted." 186 The British army, tradition-bound as it was, was populated by intelligent, experienced officers, and for them to alter their tactical system shows that they were aware of the importance of small group cohesion, and were willing to utilize it. In fact, the importance of keeping soldiers together with their comrades was

\footnotetext{
${ }^{184}$ Richard Holmes, Acts of War, 293.

${ }^{185}$ Scott Hendrix, "The Spirit of the Corps: The British Army and the Pre-National Pan-European Military World and the Origins of American Martial Culture, 1754-1783" PhD. Dissertation, Ohio State University, 2005, 272.
} 
acknowledged as far back as the days of the Roman Legions. ${ }^{187}$ While early eighteenthcentury tactical practices did not maximize small unit cohesion, by the middle of the century new battle tactics had changed that, and Hendrix's assertion that "the absence of the idea of the workplace, or of team-work put the leaders of the British Army at an intellectual disadvantage in the way they organized and utilized their manpower" seems unfounded, at least by the time of Waterloo. ${ }^{188}$

The last element of group cohesion to consider is the idea that the fixed nature of the Inniskillings' position, and the square formation that they assumed there, invokes questions of territoriality. John Keegan convincingly introduces territoriality in his discussion of the fierce fighting for La Haye Sainte and Hougomont. If it is "the case that human attackers concede to human defenders a certain claim - which one would call moral but for the ambiguity implied - to their territory," then the patch of earth at the northeast corner of the Charleroi and Brussels roads qualified as a "territory" which the Inniskillings considered their own. ${ }^{189}$ Modern proponents of the theory of territoriality emphasize the ritualized nature of combat in such instances, but that actual fighting for such places is much more fierce than usual combats. ${ }^{190}$ It is likely that the Inniskillings came to think of that square, that hilltop, as their own, a place which they would not willingly abandon.

\footnotetext{
186 J. A. Houlding, Fit for Service, 320.

187 Adrian Keith Goldsworthy, The Roman Army at War, 100 BC - AD 200 (Oxford: Clarendon Press, 1996), 257.

${ }^{188}$ Scott Hendrix, "The Spirit of the Corps", 273.

189 John Keegan, The Face of Battle, 146.

${ }^{190}$ Robert Ardrey, The Territorial Imperative (New York: Collins, 1967), 211.
} 


\section{$\underline{\text { Motivation }}$}

As mentioned above, factors that influence troop motivation can be segregated into three broad categories: initial motivation, sustaining motivation, and combat motivation. Having already dealt with many aspects of individual motivation within the broader context of the British military system, the following focuses on those issues more specific to the men of the Inniskilling Regiment of 1815.

In a recent article Peter Karsten argues that there were two central reasons that young Irishmen enlisted in the British army in the period 1792-1922. ${ }^{191}$ The first was need: wages for agricultural workers were consistently lower in Ireland than in other parts of Britain, and the volatile nature of the linen industry meant lower wages for those who worked the loom. The amount of work was variable as well; agriculture was a seasonal occupation, and industrialization of the linen process meant less work for weavers. $^{192}$

The second primary reason for Irishmen to join the British army was through a sense of tradition and a longing for adventure. Many Irish families had a long-standing military heritage. While a nominal ban on Catholics in the British army prevented service to Britain from the English Civil War until the late eighteenth century, many Irish Catholics served in Continental armies. For example, a renowned Austrian cavalry regiment of the Napoleonic era was known as the O'Reilly Chevauleger. ${ }^{193}$ As discussed earlier, when war with Revolutionary France came the British government was forced to tap the resource of Irish manpower, and the words "I am a Protestant" were deleted from the oath of attestation. But no matter their religion, young Irish men of few prospects

\footnotetext{
${ }^{191}$ Peter Karsten, "Irish Soldiers".

192 ibid., 38-39. see also Brian Mitchell, Abstract of British Historical Statistics, 200-201.
} 
would have seen an army life as a chance for adventure. Like so many young men throughout history they longed to escape the boredom of their childhood homes and see and do new things. To enlist in the army was a chance for adventure, a chance to escape.

While Karsten cites need and tradition/adventure as the two primary motivations for enlistment, he also adds a third element to the equation. The average Irish recruit was apolitical. Young Irish idealists of the late eighteenth and early nineteenth centuries of whatever background would have stayed at home and joined the Defenders, the United Irishmen, the Orangemen, or the Yeomanry to resist or aid English domination of Ireland. Apolitical men would not "view themselves as joining the British army, but as joining 'the Army.' Seven centuries of British rule, of one sort or another, had led most Irish people to accept the fact that, like it or no, they were part of the United Kingdom." ${ }^{194}$ Much of the history of Ireland of this turbulent period focuses on revolutionary activity, but there were thousands of Irish men who were more interested in joining the military for a career with regular food, pay, and the possibility of promotion and a pension.

Sustaining motivation for the Irish recruit would have been very similar to that felt by the average British soldier, as the rapid inculcation of group values was part of the process of Anglicization. The average Irish soldier "was Catholic, poor, sometimes of an adventurous, bellicose sort, apolitical, and he saw himself as a soldier by occupation."195 Given a likely background of poverty, the Irish soldier may have been especially appreciative of his rations and pay, no matter how poor they may have been. Given the apolitical nature of the Irish soldier, patriotism likely paid no role in his motivation. Support and opinions from home were possible influences on the Inniskillings, as mail

\footnotetext{
${ }^{193}$ Scott Bowden, Armies on the Danube: 1809 (Arlington, TX: Empire Press, 1980), 167.

${ }^{194}$ Peter Karsten, "Irish Soldiers", 57.
} 
services did exist; a letter to an officer or NCO cost $6 \mathrm{~d}$., a letter to a private cost only $1 \mathrm{~d}$., while $3 \mathrm{~d}$. was required to send a newspaper. ${ }^{196}$ But as the societal data contained in this thesis shows, illiteracy was rampant in much of Ireland. The 1/27th was usually stationed far from Ireland, and as will be seen in this paper's section on experience, the average soldier of the first battalion had spent seven years in the army. Most of the men had been in the army so long that the regiment was their home. ${ }^{197}$

Combat motivation of the men in the ranks of the $1 / 27^{\text {th }}$ was, again, most likely similar in nature to that felt by the other British infantry. Love of battle is a rarely mentioned but interesting possibility. Again, no mention of love of battle is made in any of the scant memoirs left by the Inniskillings, but at least one British officer enjoyed Waterloo: "I had rather have fallen that day as a British infantry-man, or as a French cuirassier, than die ten years hence in my bed. I did my best to be killed, but Fortune protected me." ${ }^{198}$

Religion served a powerful role in motivating men in the American Civil War, but the British soldier of just fifty years earlier rarely mentions it. ${ }^{199}$ There were numerous attributions such as the one above to "Fortune" or "Fate" saving them from death, harkening to early English reliance on "Providence" for victory in battle. ${ }^{200}$ Some of the more literate men showed religious training, though Private William Wheeler's lament of men dying with "no minister to cheer the dying sinner" was more a commentary on the

\footnotetext{
195 ibid., 57.

${ }^{196}$ Charles James, Regimental Companion, Vol. II, 488-189.

${ }^{197}$ Sylvia Frey, The British Soldier in America: A Social History of the Military Life in the Revolutionary Period (Austin: University of Texas press, 1981), 117-118.

${ }^{198}$ Captain Horace Churchill, quoted in Anthony Brett-James, The Hundred Days, 162.

${ }^{199}$ See James McPherson, For Cause and Comrades, and Gerald Linderman, Embattled Courage.

${ }^{200}$ Wayne Lee, Crowds and Soldiers, 114.
} 
army chaplains. ${ }^{201}$ Most modern historians agree that the men of the British army at Waterloo were "indifferent rather than hostile to religion," and that faith was only a minor factor in the motivation of British soldiers of the day. ${ }^{202}$ Again, the Irish Catholic Inniskillings seem no exception to the general religious ennui; Wellington wrote that even when his army was in Catholic Spain,

nobody goes to mass, and although we have whole regiments of Irishmen, and of course Roman Catholics, I have not seen one soldier perform any one act of religious worship in these Catholic countries, excepting making the sign of the cross to induce the people of the country to give them wine. ${ }^{203}$

Of course, Wellington was irreligious, and was notoriously unkind to those who were otherwise, but readings of other primary sources reflect that most Catholic troops were as diffident as their Protestant comrades in displays of religiosity.

The last element of personal motivation is honor, and in many ways it was the most important of the motivations. For officers, "honor defined not only who they were - gentlemen; it also defined what they did as officers - they demonstrated honor."204

Honor would have prompted officers to join the army, to stay in the army, and to do their duty in combat. But it was in combat that honor was tested, and where an officer could prove himself a gentleman. An officer did not gain honor by fighting,

it was the receipt of wounds, not the infliction of death, which demonstrated an officer's courage; that demonstration was reinforced by his refusal to leave his post even when wounded, or by his insistence on returning as soon as his wounds were dressed; and it was by a punctiliousness in obeying orders which made wounds or death inevitable that an officer's honour was consummated. ${ }^{205}$

\footnotetext{
${ }^{201}$ Private William Wheeler, Letters, 176-177.

${ }^{202}$ John Keegan, The Face of Battle, 118, see also Sylvia Frey, The British Soldier in America, 115-117, and Philip Haythornthwaite, Armies, 123-125.

${ }^{203}$ Wellington, in Anthony Brett-James, Wellington at War, 168.

${ }^{204}$ Scott Hendrix, "The Spirit of the Corps", 65.

${ }^{205}$ John Keegan, The Face of Battle, 165.
} 
In sounds as if Keegan wrote his description of honor for the officers of the 1/27th. Almost every officer was wounded; Lieutenant Fortescue was hit twice, while Lieutenant Drewe and Captain Tucker were each hit three times. Lieutenant Miller "lost the sight of his right eye by the wound of a musket ball. A bandage was applied and he returned to his post but a severe wound obliged him to return to the rear. ${ }^{, 206}$ Further, as the battalion assumed its position atop the ridge of Mont St. Jean, the officers must have known how terribly exposed they were. To assume that position without hesitation or complaint would have earned the surviving officers a life-long sense of honor.

The "post of honor" on the eighteenth-century battlefield was typically to the right of the line, and "explicitly connect[ed] the individual value of honor to the activities of a group - taking a specific (and often, in theory, more dangerous) position in the line of battle. ${ }^{207}$ General John Lambert wrote that the $1 / 27^{\text {th }}$ was posted at the right of his brigade, and the position was "honourable and fatal to the 27th Regiment, which lost more men and Officers than any Regiment during the day, and would otherwise have afforded an opportunity to the Enemy to have made an impression in a very serious part of the Line." ${ }^{208}$ Lambert's description of the Inniskilling's position fits every definition of the post of honor, and the entire battalion, in theory, at least, was honored by being placed in such an outrageously dangerous situation.

While honor was traditionally seen as an attribute of British officers, enlisted men, too, had a discernable honor code. But while an officer's sense of honor was what made him an individual, honor for enlisted men was tied to the group. Richard Holmes

\footnotetext{
${ }^{206}$ Lieutenant Charles Crowe, Memoirs, 17.

${ }^{207}$ Scott Hendrix, "The Spirit of the Corps", 290.

${ }^{208}$ General Sir John Lambert, in Siborne, Waterloo Letters, 392.
} 
sums it well: "what was honor in an abstract sense to an officer was often as tough a bond of mateship to a private." ${ }^{209}$ An officer's reputation was his ticket to society, whereas an enlisted man's reputation went no further than his battalion. But that reputation was precious nonetheless, as

a man may drop behind in the field but this is a dreadful risk to his reputation and even attended with immediate danger, while within the range of shot and shells; and woe to the man that does it, whether through fatigue, sudden sickness, or fear - let him seek death, and welcome it from the hand of a foe, rather than give room for any surmise respecting his courage; for when others are boasting of what they have seen, suffered, or performed, he must remain in silent mortification. ${ }^{210}$

Every officer and enlisted man in the $1 / 27^{\text {th }}$ had his own personal motivations. At Waterloo those men found the necessary motivations to stay together. While human motivations are terribly complicated, in the end the Inniskillings stayed together for themselves, and for each other.

\section{$\underline{\text { Relations between Officers and Men }}$}

John Lynn did not choose to have a separate part of his model to discuss leadership "because when observed on an army-wide basis, the quality of leadership itself derives from a number of other factors", such as the selection, promotion, and training of officers. $^{211}$ While Lynn's decision was certainly best for his examination of the Armée $d u$ Nord, the focus of this thesis is more intimate; the study of a battalion begs for a discussion of the relations between officers and men.

The key to understanding the relationships between the officers and men is the knowledge that each group had expectations of the other. John Lynn explains:

\footnotetext{
${ }^{209}$ Richard Holmes, Redcoat, 400. For more on honor amongst common men see Robert Davis, The War of the Fists (New York: Oxford University press, 1994).

${ }^{210}$ Corporal James Anton, quoted in Muir, Tactics and Experience, 201.

211 John Lynn, Bayonets of the Republic, 38.
} 
Relationships between officers and men derive not only from the social distance or proximity of the two groups but also from expectations and attitudes. Case studies of different armies and different time periods suggest that the leader is most effective who most closely matches the ideals of leadership held by his men. ${ }^{212}$

In combat the officers expected obedience from their men, and the men expected bravery and skill from their officers. As in all matters of human relations the issue was not that cut and dried; how enlisted men and their officers interacted in light of their mutual expectations is the heart of the matter. It is important to note that the British army of the late eighteenth and early nineteenth centuries was built to have a substantial gap between the officers and their men. All British society was founded on that concept of "leaders" and "led". But there were instances where that gap could be narrowed, or in places bridged, in order to better the performance of the army. For example, while in barracks in England the $51^{\text {st }}$ Foot held occasional field days, in which the battalion Colonel would participate. Playing football with the men, the Colonel would say, "Don't give way to me, we are now all on a level, there is no difference in rank. Jack's as good as his master." This equality was very brief, and the battalion quickly returned to the requisite distance between officers and men, but that glimpse of shared humanity prompted Private Wheeler of the $51^{\text {st }}$ to say that "I belong to as good if not the best Regiment in the service. ${ }^{213}$

If the officers expected obedience from their men, the best officers knew how to earn the trust and respect of their men, and hence their obedience in combat. Two of the most prolific British diarists of the Napoleonic Wars left descriptions of successful commanding officers, both of whom had ties to Ireland. Lieutenant William Grattan of

\footnotetext{
212 ibid., 92.

${ }^{213}$ Private William Wheeler, Letters, 230.
} 
the $88^{\text {th }}$ Foot, the Connaught Rangers, left an account of Colonel Alexander Wallace.

Wallace commanded an Irish battalion, and "although a Scotchman himself, he was

intimately acquainted with the sort of men he had under him, and he dealt with them and

addressed their feelings in a way that was peculiar to himself and suited to them."214

Private William Wheeler of the 51st Foot praised the qualities of an officer of that

regiment:

Captain Dyas could not boast of high birth or fortune, but he had a lion's heart. Ireland never produced a better soldier, nor one more qualified to fill a high station in the army, being in possession of that secret how to govern those under him not through fear but love. We are all rejoiced at his promotion. But sorry for his leaving the Regiment. ${ }^{215}$

Two key points to glean from these quotes are that both officers grew close to

their men and earned their trust, and that they then utilized that trust to ensure the

obedience of their men. To simply earn trust was an empty victory; to demand obedience without trust was equally futile; only the sequential combination of trust and obedience guaranteed success in combat.

A further example of an officer who combined trust and affection with obedience

comes again from Private Wheeler, who wrote of Major Douglas, who

stood high as a brave soldier, but he was in possession of another virtue rarely to be met with to so great a degree in any man - it was a noble generosity and good will that he extended to all about him. He had acquired the appellation of "father" by his company, by whom he was almost idolized. By the Regiment at large he was highly beloved and respected. Notwithstanding he was a strict disciplinarian, but somehow, he never had any trouble in keeping his men in order, as a look or a word from him had more effect than 500 lashes would from some officers. Our regret for his loss can be much easier imagined than described". ${ }^{216}$

\footnotetext{
${ }^{214}$ Lieutenant William Grattan, Adventures, 86.

${ }^{215}$ Private William Wheeler, Letters, 236-237.

${ }^{216}$ ibid., 145.
} 
It should again be pointed out that while this officer was cherished for his bravery and kindness, he was also an effective officer. He was not weak in dealing with his men, and expected instant obedience. The fatherly manner in which he led his men was what separated him from other officers; the paternalistic role of the officer was to become a trademark of superior British officers in the years to come. ${ }^{217}$

Emotional involvement as an element in leadership was a critical element for some officers, but not for all. Some officers were either incapable or unwilling to become emotionally attached to their men. Other officers deliberately masked their emotions in order to stay efficient in combat, or to avoid the pain of loss. Wellington, for example, did his utmost to banish "feeling from his personality. The decision to do so was deliberate and the effort by which he achieved it intellectual.,"218

Just as the officers had expectations of their men, so too did the men have expectations of bravery and competency in their officers. An examination of the memoirs left by veterans of the Revolutionary and Napoleonic Wars gives solid evidence of what British soldiers expected from their officers. Sergeant Edward Costello of the $95^{\text {th }}$ Rifles wrote that "our men divided the officers into classes: the 'come on' and the 'go on.",219 Bravery was the sine qua non of the British officer: it was expected of him by his men, and was expected of him by his brother officers. Lieutenant Grattan's description of Colonel Wallace went on to stress that he "was eminently calculated to head a division, because he not only possessed that intrepidity of mind which would brave any danger, but genius to discover the means of overcoming it." ${ }^{, 220}$ Personal bravery and competency

\footnotetext{
${ }^{217}$ John Keegan, The Face of Battle, 243-245.

${ }^{218}$ John Keegan, The Mask of Command, 162.

${ }^{219}$ Sergeant Edward Costello, quoted in Gunther Rothenberg, The Art of Warfare, 180.

${ }^{220}$ Lieutenant William Grattan, Adventures, 86.
} 
were the factors that bonded Wellington to his army. At Waterloo he was continuously exposed to enemy fire, and while almost his entire staff was wounded he was unscathed. His competency brought them victory, so while "Wellington was feared, he was esteemed most highly."221

Another way for officers and enlisted men to bond was through shared suffering. One honest, if ill-used, officer at Waterloo complained that his memories of Waterloo were limited: "I'll be hanged if I know anything at all about the matter, for I was all day trodden in the mud and galloped over by every scoundrel who had a horse."222 This brief comment summarizes the battlefield experience of many Waterloo veterans, officers and enlisted men.

There were ways in which the enlisted men and their officers could bond, but there just as many ways by which the social and military gap between the two groups could remain unbridged. There were men in the ranks who were brave, loyal, and obedient, but there were also some violent, drunken, malcontents. There were brave, intelligent, kind officers, and cruel, stupid, martinets. As in most human societies, the great majority of the men fell somewhere between the two extremes.

In those instances in which where there remained a wide gap between the officers and the men there was often considerable animosity. It would be a mistake to assume that in a military organization only the officers possessed the power in such a relationship. While the officers, of course, directed the considerable power of the disciplinary system, the men too had ways, however limited, of striking back at despotic officers. Throughout history unpopular officers have always risked death at the hands of

${ }^{221}$ Captain Thomas Brotherton, A Hawk at War, Bryan Perrett, ed., (Cippenham: Picton Publishing, 1986), 76. 
their own men, and the Napoleonic Wars were no exception. There are few documented cases, but in the dense smoke, noise, and confusion of battle there were instances in which disaffected men killed their officers. Two days before Waterloo, "Lieutenant Colonel John Cameron of Fassiefern, formidable commander of the $92^{\text {nd }}$ in the Peninsula and Hundred Days, was shot at Quatre Bras by a bad character he had flogged not long before, although it is impossible to be certain., ${ }^{223}$

Even outside the battlefield there were instances of men killing their officers. In 1813 the $42^{\text {nd }}$ Foot, the Black Watch Highlanders, was billeted in scattered villages in Spain. One company was billeted on a remote village, commanded by only one very young lieutenant named Dickinson. An Irish corporal of the company named M'Morran soon fell in love with a local girl, and Dickinson grew jealous. Dickinson was far removed from his fellow officers, and if he lacked their company and support, he also lacked the restraint they may have placed on him. When the young woman spurred Dickinson's advances, he threatened to break and flog M'Morran, whereupon M'Morran shot and killed his Lieutenant. M'Morran was arrested and eventually hung, but "always said he was not sorry for what he had done." Further, before his execution the battalion adjutant abused M'Morran, and M'Morran warned the adjutant that there were men in the ranks ready to murder him, as well. ${ }^{224}$ While the option of murder was an extreme one, there were instances in which enlisted men felt they had no option but to kill officers who oppressed them, and all officers had to keep that possibility in the back of their minds.

\footnotetext{
${ }^{222}$ Captain John Kincaid, Adventures, 273.

${ }_{223}$ Richard Holmes, Redcoat, 393.

${ }^{224}$ Anonymous, Personal Narrative of a Private Soldier Who Served in the Forty-Second Highlanders for Twelve Years, during the late War (London: Ken Trotman, 1996), 46.
} 
Sadly there are no detailed memoirs written by or about the officers who commanded the $1 / 27^{\text {th }}$ at Waterloo. There are, however, some contemporary comments that give clues regarding Irish soldiers and their officers. Some officers felt that Irish recruits were easy to work with. One officer who had transferred from a Scottish regiment to an Irish regiment commented: "If you had been, like me, accustomed to deal with the Glasgow weavers, in the shape of soldiers, you would enter into the delight I have in commanding these lighthearted, willing, easily-managed fellows., 225

The loyalty that Irish soldiers felt toward their officers held the Irishmen in the ranks when Irish nationalists tried to lure them into joining their cause. One such conversation is recorded, as a nationalist approached the barracks of the $88^{\text {th }}$ Foot, the Connaught Rangers, and

asked a soldier of the Depot battalion if he would shoot his commanding officer if told to do so, to which the man replied: 'Indeed I would not - the major is too good a man to be shot; but if he told me to shoot you, I would put a hole through you as soon as look at you. ${ }^{226}$

The officers of the $1 / 27^{\text {th }}$ may or may not have been emotionally attached to their men, but their bravery cannot be doubted. Sixteen of the nineteen officers at Waterloo were killed or wounded, and some were wounded multiple times. The defining element of the British officer of the day was bravery, and the officer corps of Inniskilling Regiment passed that test.

\footnotetext{
${ }^{225}$ Anonymous officer quoted in O'Callagahan, The Irish in the English Army (Dublin: Butler Press, 1843), 14.

${ }^{226}$ Colonel Horatio Shirley, quoted in Peter Karsten, "Irish Soldiers", 60.
} 


\section{The Military System}

A significant portion of the organizational framework utilized by John Lynn in The Bayonets of the Republic is titled "The Military System", which details "the basic tools, techniques, procedures, and structures of the army on campaign and in battle". The discussion of the military system consists of five subsystems: disciplinary, tactical, administrative, organizational, and command. ${ }^{227}$

While this thesis will follow Lynn's structure and the resultant five subsystems, it will not always follow Lynn's methods or arguments within those subsystems. This is partially due to this work's focus on a battalion rather than an army, and partially due to the information available with which to make useful arguments.

\section{Disciplinary System}

Discipline in the British army during the Revolutionary and Napoleonic eras was largely based on a system of punishments. The systems for officers and enlisted men were wholly different. The potential punishments for officers were based on loss of honor and or professional status for all but the most serious offences, while the punishments for enlisted men were primarily corporal.

Any soldier accused of a serious crime, whether officer or enlisted man, would be tried by general court martial. Five officers would serve as a jury, while the role of prosecutor would be filled by an army Judge Advocate or an accuser from within the army. Strict rules of evidence and procedure gave the process at least the trappings of English justice, though the range of punishments that could be imposed by the court was very limited. The range of punishment for officers was suspension, reprimand, displacement, cashiering, or

\footnotetext{
${ }^{227}$ John Lynn, Bayonets of the Republic, 36.
} 
death. Sergeants and corporals could be punished by reduction to the ranks, flogging, or death. The only punishments that could be imposed on privates were flogging or death. ${ }^{228}$ Lesser crimes by enlisted men were tried by regimental court martial. The battalion adjutant would act "in the capacity of advocate for the prisoner, to see that justice is done, no irregularity occurs, from any misapprehension or mis-interpretation of the articles of war."229 The battalion's officers had considerable latitude in the proceedings, but some rules existed to protect the common soldiers' rights. One such regulation stated that no non-commissioned officer could be reduced to the ranks without trial by court martial, thus protecting veteran sergeants and corporals from the abuses of "unfledged ensigns and ignorant martinets." Every soldier had the right of appeal to a general court martial, but risked additional punishment from that body except in the rare cases where the general court martial overturned the earlier verdict of the regimental officers. ${ }^{231}$

Some regiments held non-regulation company-level courts martial administered by NCOs. The court would be run along the lines of a formal court-martial, though the company commander would have to approve the court's decisions. Punishments would usually consist of "scabbarding," a beating delivered by the other men of the company. ${ }^{232}$ Another innovative means devised for a man to be punished by his fellow soldiers was carried out by the $51^{\text {st }}$ Foot in 1809. A man who had deserted was sentenced to five hundred lashes, but was given only seventy-five. He was then marched between the ranks while the commanding officer shouted "soldiers, spit on the cowardly poltroon, you should all piss over him if it were not too indecent". 233

\footnotetext{
${ }^{228}$ Charles James, Regimental Companion, 342-353.

${ }^{229}$ ibid., 356.

${ }^{230}$ ibid., 358

231 ibid., 358.

${ }^{232}$ ibid., 365

${ }^{233}$ Sgt. William Wheeler, Letters, 11.
} 
When on campaign soldiers accused of serious crimes were handed over to the Provost Marshal for later trial, while lesser offences were tried at drum head courts martial. In the field rules of evidence and supporting testimony were easily forgotten, and floggings could be carried out at a moment's notice. The battalion's drummers were responsible for carrying out the floggings, and they were to carry their cat-o-nine-tails with them at all times. A triangle of sergeant's spontoons would be used to hold the offender upright, and the prescribed punishment inflicted immediately. ${ }^{234}$ The number of lashes was largely determined by regimental custom or indeed the whim of the commanding officer. For example, in Spain between 1812 and 1814 the $10^{\text {th }}$ Hussars had 136 punishments, with an ordered 34,300 lashes. That is an average sentence of more than 250 lashes, ranging from 600 for plundering to 50 for stealing. ${ }^{235}$

By all accounts flogging was exceptionally painful. One flogged soldier wrote that the first stroke felt "as if a knife had gone through my body" and upon receiving the second stroke he thought "the former stroke sweet and agreeable compared to that one." $" 236$ A modern experiment with the heavy naval cat-o-nine-tails showed that one blow easily shatters wooden planks; the effect on the human body must have been horrific. ${ }^{237}$

The frequency of flogging, and the number of lashes inflicted, was a topic of debate both within the army and the general public of the day. Reformers such as William Corbett challenged the practice of flogging in the press and in Parliament. While flogging seems to be an exceptionally harsh form of punishment, at least one modern scholar argues that it was the only available method "that could control the appalling thugs of whom the rank and file of

\footnotetext{
${ }^{234}$ ibid., 185.

${ }^{235}$ Phillip Haythornthwaite, Armies, 68.

${ }^{236}$ Alexander Somerville quoted in Holmes, Redcoat, 323.

${ }^{237}$ Dudley Pope, The Black Ship (New York: Henry Holt \& Company, 1963), Appendix A, 339-340.
} 
the British army was largely composed." ${ }^{238}$ Another historian disagrees as to the proportion of thugs, but agrees that "few with actual experience of the army doubted the necessity of the strictest discipline, if only to control the small number of genuine bad characters. $" 239$

It should also be stressed that harsh physical punishment was an inherent part of the British justice system of the eighteenth and early nineteenth centuries. Those were harsh times, and "in the context of an age of brutality, where in civilian life children were hanged or transported for petty theft, military flogging was not so specially cruel as it may appear in context." ${ }^{240}$ Civilian justice had some punishments that were not available to military authorities, including transportation, fines, imprisonment, and military service. These punishments would have been deemed to have been on the same level as the military's flogging policy. For example, Irish jails were notorious for their brutality, filth, and cruelty, as "there was no bedding; the floors were of stone; there was no attempt to separate the young offenders from the old, the women from the men, or the sick from the healthy." ${ }^{241}$ Like the military, civil justice also utilized execution and flogging. But the prime similarity between civilian and military justice was its harshness, and the physical punishment within the army would not have been viewed as extreme by men leaving civilian life. ${ }^{242}$

There are no records of the discipline meted out by the Inniskilling officers in 1815 . There are, however, some entries in the rosters of the first battalion that hint at the disciplinary practices. First, as has been pointed out earlier, the officers and NCOs of the $1 / 27^{\text {th }}$ were men of exceptional experience, and had served with the bulk of the enlisted men for many years. While there is no way to quantify the theory, it can be surmised that that

\footnotetext{
${ }^{238}$ Richard Glover, Peninsular Preparation, 174-175.

${ }^{239}$ Phillip Haythornthwaite, Armies, 66.

${ }^{240}$ Correlli Barnett, Britain and Her Army, 1509-1970: A Military, Political, and Social Survey (New York: William Morrow \& Company, 1970), 241.

${ }^{241}$ Thomas Pakenham, Year of Liberty, 278.

242 Philip Haythornthwaite, Armies, 65-71.
} 
long service had given both officers and men such familiarity with their roles and with each other that established cultural norms prevented some of the more usual sources of friction.

Secondly, the number of desertions can be used as an indication of the "contentedness" of the battalion. Men who felt they were being treated unfairly or with excessive harshness would be more likely to desert. The final pages of British infantry pay rosters were reserved for disposition of men who had died of disease or had deserted. The Inniskilling rosters from May 1815 and June 1816 show that less than ten men deserted from the $1 / 27^{\text {th }}$. A desertion rate of less than one percent was remarkably low. Few statistics are available on desertion rates in Napoleonic armies, but some recent work on eighteenthcentury armies suggests annual desertion rates averaging between two and eight percent. ${ }^{243}$ The results of studies on eighteenth-century armies are very applicable to the British army of the Napoleonic Wars, as the British army was very much an ancien regime army in the composition of its forces, the relationships between its officers and men, and in its disciplinary methods. The extremely low rate of desertion found in the $1 / 27$ th may indicate that the officers and NCOs of the $1 / 27^{\text {th }}$ kept very tight reins on their men, but just as easily can be interpreted as a general level of contentment of the men with their life in the regiment.

Lastly, the pay rosters can be used to determine the number of NCOs demoted back to private. As mentioned above, demotion was one of the few non-corporal punishments that could be inflicted on NCOs. This loss of pay and prestige was a serious blow to a soldier who may have spent years in search of promotion. For example, in the four months between September and December 1815 no sergeants lost their positions, and only four corporals were demoted back to private. ${ }^{244}$ No mention is made of the causes of the demotions, but all four demotions occurred after the campaign, when the battalion was in camp near Paris. The

\footnotetext{
${ }^{243}$ Michael Sikora, Disziplin und Desertion; Strukturprobleme militärischer Organisation im 18. Jahrhundert (Berlin: Dunker \& Humbolt, 1996), 70-71.
} 
rosters for the four months that include the battle of Waterloo (May to August 1815) are significantly different: four sergeants and twelve corporals were demoted to private. ${ }^{245}$ This difference between camp discipline and campaign discipline is striking. In camp the men were in a comparatively controlled environment, while on campaign there were many more opportunities for men to draw the wrath of the officers. Wellington wrote that "when the army is quietly encamped in a position or in cantonments, all goes on well enough, and the ordinary regimental discipline is sufficient to keep the soldiers in tolerable order; but when an exertion of any kind is to be made, the whole machine falls to pieces."246 Plunder, drink, civilians, and opportunities to stray from the ranks were all hazards in the field, while the stresses of battle would quickly reveal the NCOs who were not up to the challenges of combat leadership.

In light of the three factors mentioned above, it can be estimated that discipline in the $1 / 27^{\text {th }}$ was comparatively controlled; the behavior of the men was not outrageous, and the punishments meted out by the officers was not excessive. But the battalion was not immune to the discipline problems inherent in the British army. The rosters completed in December 1815 show that $£ 21$ s. was paid out as a reward for the return of two deserters. ${ }^{247}$

Interestingly, $£ 11$ s. was paid for one man, while the second was worth only $£ 1$. The names and fates of the two men were not recorded, but their punishment was doubtless very severe. Desertion in war time was sometimes deemed a capital crime, and even in times of peace a flogging of 1,000 lashes was not unknown. ${ }^{248}$

Lastly, the Inniskilling's pay rosters for the year after Waterloo show that two men were executed by order of a general court martial on Aug. $2^{\text {nd }}, 1816$. Matthew Dunnegen, a

\footnotetext{
${ }^{244}$ United Kingdom War Office, $1 / 27^{\text {th }}$ Regimental rosters, $1815-1816$.

245 ibid.

${ }^{246}$ Wellington to Colonel Henry Torrens, March 1814, in Anthony Brett-James, Wellington at War, 290.

${ }^{247}$ United Kingdom War Office, 1/27 ${ }^{\text {th }}$ Regimental rosters, 1815-1816.
} 
former laborer from the County Longford, and James Brennan, a former laborer from the County Monaghan, served in the same company, and were both veterans of Waterloo. They survived the battle only to die together in a camp outside Paris well after the war ended. Their crime is not recorded, nor is the method of their execution. ${ }^{249}$ Normally civil crimes were punished by hanging, while capital military crimes were punished by death by firing squad. $^{250}$ Soldiers typically abhorred hanging, as one British officer wrote at one execution, as he "should have given the world to have saved him the ignominious sort of death that he was to suffer, for his chief horror seemed not so much the fear of death itself as the mode of it, beseeching as a favor to be shot as a soldier, not hanged as a felon." ${ }^{251}$ Interestingly, the only desertion in that time period was by a man of the same company, a County Down tailor named Daniel McCahey, just two weeks after the executions. It may be coincidence, but McCahey may have been escaping a role in the crime that claimed the lives of his fellow soldiers, or was perhaps fleeing what he felt was an unjust environment. The officer commanding that company was new to the regiment after the severe losses suffered by the officers at Waterloo; it may be that the new officer's disciplinary methods were harsher than the standards set by the highly experienced men who fell at Waterloo.

Lastly, it must be remembered that the officers were not immune to discipline problems. Captain John Montmorency Tucker, the third most senior officer of the $1 / 27^{\text {th }}$ at Waterloo, was tried by a court martial for "scandalous and infamous conduct" just weeks after the battle. Specifically, Tucker was accused of the possession of two horses not belonging to him, and having broken into the baggage of a fellow officer who had been killed in the battle. No details of his alleged crime are recorded, but Tucker was found guilty and

\footnotetext{
${ }^{248}$ Richard Holmes, Redcoat, 324.

${ }^{249}$ United Kingdom War Office, $1 / 27^{\text {th }}$ Regimental rosters, $1815-1816$.

${ }^{250}$ Richard Holmes, Redcoat, 317.

${ }^{251}$ Captain Thomas Brotherton, A Hawk at War, 78.
} 
dismissed the service. This was a terrible punishment for an officer in an army in which an officer's personal honor was the core of his being. Curiously, the judgment against Tucker was reviewed by Wellington and the Prince Regent, and it was ordered that Tucker only be placed on half pay due to irregularities in the court proceedings. Even that sentence seems not to have been implemented, as the Army List of 1817 show that Tucker exchanged from the 27 th into the $8^{\text {th }}$ Foot in May, $1816^{252}$

The fact that Tucker was accused and found guilty by his fellow officers shows that even such honor-bound men were capable of human transgressions. While the nature of the irregularities of the regimental court martial is not recorded, for the regimental process to be so flawed as to require the intervention of the commander in chief raises questions as to the bias of the officers who composed it. For the court's sentence to be overridden due to irregularities shows that serious rifts may have existed within the ranks of the Inniskilling officers. Indeed, the impartiality of the court martial system could have been called into question, as a review by higher command could either correct injustices or protect the guilty. Just as wealth and high social status were important factors in the promotion of officers they could also taint the impartial imposition of justice.

\section{Tactical System}

The tactical system employed by the Inniskillings and the British infantry in general consisted of a wide variety of components, divisible into weapons, doctrine, tactics, training, and experience.

Every British infantryman at Waterloo carried a weapon. While a few specialized units carried the Baker rifle, every enlisted man in the British line regiments, including the Inniskillings, carried the East India Pattern smoothbore musket: the ubiquitous Brown Bess.

\footnotetext{
${ }^{252}$ United Kingdom War Office, Army Lists, Military Records Information 73.
} 
The musket was 55 inches long, and with the bayonet attached it measured 73 inches.

Weighing nearly 11 pounds, the weapon was long, heavy, and awkward. ${ }^{253}$

The Brown Bess was very similar to the muskets borne by French and Prussian infantry in that they were wildly inaccurate by modern standards. Musket balls were not perfectly round, thus allowing air pressure to affect the flight of the ball. Worse, the balls were of a much smaller caliber than the musket barrel. This difference allowed the weapon to be loaded quickly, but when the musket was fired the ball bounced erratically down the barrel, thus making accuracy problematic at best. ${ }^{254}$

These weapons could be used effectively, but only at close range. A British officer wrote in 1814 that a musket ball "will strike a figure of a man at 80 yards- but a soldier must be very unfortunate indeed who shall be wounded by a common musket at 150 yards provided his antagonist aims at him; and as to firing at a man at $200 \ldots$ you may as well fire at the moon." 255

The British infantrymen carried an extra flint for the musket's lock, as well as sixty cartridges. The cartridges were made of heavy greased paper holding the ball and powder, and it was vitally important that they be kept dry. ${ }^{256}$ In wet conditions flintlock muskets were essentially useless, and foot soldiers had to rely on their bayonets.

The British bayonet was a triangular blade, typically 15 inches long. It was fixed to the musket's muzzle by a cylindrical socket that still allowed the musket to be fired with the bayonet attached. The bayonet was carried in a black leather scabbard on the left hip. ${ }^{257}$

Another edged weapon found in the ranks of British infantry regiments was a ninefoot pike carried by sergeants. This weapon, the "spontoon", replaced the traditional halberd

\footnotetext{
${ }^{253}$ Surviving original at Inniskilling Regimental Museum, Enniskillen, Northern Ireland.

${ }^{254}$ Otto von Pivka, Armies of the Napoleonic Era (New York: Taplinger Publishing Company, 1979), 62.

${ }^{255}$ Colonel George Hanger, quoted in Mark Adkin, Waterloo, 166.

${ }^{256}$ Gunther Rothenberg, Art of War in the Age of Napoleon, 67.
} 
which had been carried by British sergeants since medieval times. The spontoon was useful in dressing ranks, when it could be turned horizontally and used to force men into place. But the spontoon also served as a designation of rank and authority, and acted as a physical symbol of the sergeant's status. ${ }^{258}$

Another weapon that served as a mark of authority was the sword carried by the British infantry officer. Regulations dictated a straight-bladed cut and thrust weapon, which Captain Cavalié Mercer thought "was good for neither cut nor thrust, and was a perfect encumbrance."259 But the primary purpose of the infantry officers' sword was not close combat. In the infantry only officers carried swords; it was a mark of their rank, authority, and status as gentlemen.

While the weapons carried by the soldiers of the $1 / 27^{\text {th }}$ seem hopelessly antiquated by modern standards, at the time they were proven, reliable, and were at least the equal of the weapons carried by their opponents. In all of the primary sources consulted for this thesis, there was not one complaint made by British enlisted men regarding the quality of their weapons--a fact which stands in stark contrast to the frequent complaints of enlisted men of other eras.

British infantry tactical doctrine of the Napoleonic Wars was dominated by a 1788 work entitled Principles of Military Movement by Sir David Dundas. As Commander in Chief of the British Army, the Duke of York ordered that Principles of Military Movement become the standard drill for the entire army. Later works such as Rules and Regulations for the Formations, Field Exercise, and Movements of His Majesty's Forces built upon the

\footnotetext{
${ }^{257}$ Surviving original at Inniskilling Regimental Museum, Enniskillen.

${ }^{258}$ ibid.

${ }^{259}$ Cavalié Mercer, Journal, 167.

${ }^{261}$ Great Britain, Army, Infantry, Rules and Regulations
} 
Dundas work by standardizing the training of recruits and formalizing the complex movements of every military unit from squad to brigade. ${ }^{261}$

Dundas' work was disdainful of the light infantry tactics and two-rank lines that had been developed in the American Revolution, and instead dictated a return to the ancien regime tactics of Frederick the Great of Prussia. The official disregard for the tactical innovations of the American Revolution was seen as an insult by General Lord Cornwallis, who was otherwise the most traditional of British Generals. ${ }^{262}$ Later editions of Principles of Military Movement also ignored the columnar innovations of the French Revolutionary armies. British army doctrine remained a relic of a traditional system that relied on ancien regime maneuver and tactics.

The formal doctrine developed by Dundas and his adherents also dictated machinelike movements for the individual soldier. Very detailed and structured text and illustrations explained every duty of the soldier; individual action and initiative had no role in the official army doctrine.

Tactics of the Revolutionary and Napoleonic Wars were based upon the deployment and employment of three primary arms: infantry, cavalry, and artillery. The interplay between those elements was key to the success of every army of the day. In all those armies, but especially in the British army, infantry was the most important of the three arms. Of the three arms only infantry could hold ground. Infantry also had the ability to inflict casualties by fire, though to a lesser extent than artillery. Lastly, infantry had the ability to maneuver and close with the enemy, though to a lesser extent than cavalry. ${ }^{263}$ Infantry was also the

\footnotetext{
${ }^{262}$ Park and Nafziger, The British Military: System and Organization 1803-1815 (Cambridge, Ontario: the Rafm Company, 1983), 32.

${ }^{263}$ George Jeffrey, Tactics and Grand Tactics of the Napoleonic Wars (Brockton, MA.: The Courier Publishing Company, 1982), 26.
} 
least expensive of the three arms, and thus was always the most numerous arm on the battlefield. During the campaign of 1815 the Anglo-allied army consisted of: ${ }^{264}$

$$
\begin{aligned}
& \text { Cavalry - } 106 \text { squadrons..........16,225........14\% } \\
& \text { Infantry - } 129 \text { battalions...........87, 132 .......78\% } \\
& \text { Artillery - guns, engineers, etc....8,643 .......8\% }
\end{aligned}
$$

During the Revolutionary and Napoleonic Wars most infantry fought in close order.

A few specialized units would deploy to skirmish with the enemy, but the majority of the infantry was deployed in either line, column, or square. Line formation was utilized to bring all available firepower to bear, but it was exceptionally difficult for a battalion to maintain its order when attempting to move in line. Column, on the other hand, was the optimal formation for movement, but only the handful of men in the front of the column could fire on the enemy. Square formation was used by infantry when the battalion was threatened by cavalry. In the British army the formation was actually rectangular, with men facing in all four directions. The men in the front rank of the square would kneel and present a wall of bayonets to dissuade cavalrymen from closing. ${ }^{265}$ Most modern readers are not familiar with horses, and may not be aware that even well-trained cavalry mounts could not be forced to throw themselves onto a wall of bayonets, or anything else that the horse felt was too dangerous.

At Waterloo all British infantry in line formation were deployed in two ranks. The British infantry were thus able to bring more firepower to bear than the three-deep French and Prussian infantry. Three rank lines offered less firepower, but had the advantage of a denser formation that kept the men closer to their officers. Further, when the battalion suffered casualties the third rank was readily available to step forward and fill any gaps. ${ }^{266}$

\footnotetext{
${ }^{264}$ Scott Bowden, Armies, 319.

${ }^{265}$ Brent Nosworthy, Battle Tactics, 120-122.

${ }^{266}$ Rory Muir, Tactics and Experience, 71.
} 
Each British infantryman was to occupy twenty-two inches, and touch elbows with

the men on either side. Lt. William Grattan wrote that his commanding officer stressed the importance of that contact as their battalion drilled:

He would explain to the soldiers what he expected them to do; if in danger of being charged by cavalry he would say, "Mind the square; you know how I often told you that if ever you had to form it from line, in face of an enemy, you'd be in a dammed ugly way, and have plenty of noise about you; mind the tellings off; and don't give the false touch to your right or left hand man; for by God, if you are once broken, you'll be running here and there like a parcel of frightened pullets!". ${ }^{267}$

While the men in each rank were to be touching elbows with the men on either side,

the two ranks were to be just thirty inches apart. Each man in the rear rank was to be aligned with the file leader. The company commander was to be on the far right of the company, with a sergeant in the rear rank to cover him. A third, or supernumerary rank, consisting of the other company officers and sergeants was drawn up three paces behind the rear rank. ${ }^{268}$

The perfection of the regulation formation did not survive the stress of combat:

What precision of aim can be expected from soldiers when firing in line? One man is priming; another coming to the present; a third taking, what is called aim; a fourth ramming down his cartridge. After a few shots, the whole body are closely enveloped in smoke, and the enemy is totally invisible; some of the soldiers step out a step or two, in order to get a better shot; others kneel down; and some have no objection to retiring a step or two. The doomed begin to fall, dreadfully mutilated perhaps, and even bold men shrink from the sight; others are wounded, and assisted to the rear by their comrades; so that the whole becomes a line of utter confusion, in which the mass only think of getting their shot fired, they hardly care how or in what direction. $^{269}$

Primary sources agree that the $1 / 27^{\text {th }}$ was in a column of companies at quarter

distance when they first took their place in the Anglo-Allied line, but were in square for most of the afternoon. Their ranks would quickly have been disordered as the men reacted to the environment of smoke, noise, and fear. Dead and wounded men would have been

\footnotetext{
${ }^{267}$ William Grattan, Adventures, 86.

${ }^{268}$ Great Britain, Army, Rules and Regulations, 32.
} 
everywhere. Nevertheless, the tactical system was of sufficient depth and resiliency to give the Inniskillings the ability to sustain their will in spite of the terrible losses they suffered.

The training of the British infantryman was fully described by the Rules and Regulations of $1792 .^{270}$ The training program was to start with the training of the recruit as an individual, then the individual as a part of a company, then the company as part of a battalion, and finally the battalion as a part of the line of battle.

Every phase of the training was explained in great detail. For example, the recruit was to be treated with patience, and much of the responsibility for training was placed upon the officers and NCOs. Every part of the soldier's movements was to conform to the army standard:

In marching, the soldier must maintain, as much as possible, the position of the body as directed in Sect. I. He must be well balanced on his limbs. His arms and hands, without stiffness, must be kept steady by his sides, and not suffered to vibrate. He must not be allowed to stoop forward, still less to lean back. His body must be kept square to the front, and thrown rather more forward in marching than when halted, that it may accompany the movement of the leg and thigh, which movement must spring from the haunch. ${ }^{271}$

The essence of a soldier's training was focused in two areas: weapons drill and marching. Black-powder weapons were very dangerous in untrained hands, and through endless repetitions the eighteen-step manual of arms rendered the recruit more a threat to his enemies than to his friends. The manual of arms was complicated, but the elements of marching spelled out in the regulations are so complicated as to defy belief. The marching drills for the recruit require twenty-seven pages, the company drill is twenty-four pages long, and the battalion evolutions require one hundred ninety-seven pages of precise detail. ${ }^{272}$

\footnotetext{
${ }^{269}$ Lt. Colonel John Mitchell quoted in Brent Nosworthy, Battle Tactics, 209.

${ }^{270}$ Great Britain, Army, Rules and Regulations

${ }^{271}$ ibid., 6.

272 ibid., et al.
} 
Based on the amount of indoctrination and training that the men had to absorb, Lt.

Colonel William Napier believed "that it took three years to make infantry fully disciplinedas opposed to just fit to take the field, which might take only a few weeks."273 Modern scholars agree; J. A. Houlding's detailed analysis of British infantry battalions between 1715 and 1795 suggests that two to three years were necessary to bring a new battalion up to combat efficiency. The same time period was required to re-build a unit that had been broken by extended campaigning. ${ }^{274}$

The recruit's transformation from civilian to soldier was to be total. The officers and NCOs were to do whatever was necessary to make a soldier, as "too many methods cannot be used to supple the recruit, and banish the air of the rustic." ${ }^{275}$ The rustic recruit was to be transformed,

as new recruits, coming straight from the villages, could be fitted into the artificial community of the company and platoon with minimal psychological adjustment. For drill swiftly and dependably transformed obedience and deference defined by custom into obedience and deference defined by regulations. $^{276}$

The rhythmic precision of drill was originally intended solely to get bodies of men to move as a group in a prescribed manner, but a modern scholar contends that drill had another, more visceral, effect. William H. McNeill contends that close-order drill was, like dance, a shared group rhythmic muscle activity that bonded men together at the most primal levels. The theory is unproved, but intriguing. ${ }^{277}$

The enlisted man was responsible for his role in every part of the drill, but much of the text of the regulations was intended for the training of the battalion's officers. The Rules

\footnotetext{
${ }^{273}$ William Napier quoted in Rory Muir, Tactics and Experience, 75.

${ }^{274}$ J. A. Houlding, Fit for Service, 295.

${ }^{275}$ Great Britain, Army, Rules and Regulations for the formations, field-exercise, and movements, of His Majesty's forces, 3.

${ }^{276}$ William H. McNeill, The Pursuit of Power, 132.

277 William H. McNeill, Keeping Together in Time: Dance and Drill in Human History (Boston: Harvard University Press, 1995)
} 
and Regulations dictated that every officer should be familiar with all the evolutions required by the enlisted men, and also with his own responsibilities. The regulations stipulated that "till he is master of those points, and capable of instructing the men under his command, he is not to be permitted to take the command of a platoon in the battalion". ${ }^{278}$ There were, however, officers who were incapable of maneuvering their men; Lt. William Grattan wrote of "one old Major who, having once gotten his battalion into square, totally forgot how to get it out of it." 279

Lieutenant Grattan’s “old major” had evidently neglected his study of Part II, Section 98, of the Rules and Regulations, regarding "counter-march from the center." ${ }^{280}$ The number of wheels, pivots, and halts in the regulations defies belief, and the modern scholar has to question if any unit had the time and motivation to train their officers and men to a full knowledge of the regulations. Further, the usefulness of this type of Frederician maneuver was outdated by the doctrines of speed and mass that were the hallmarks of the Napoleonic wars.

Drilling experienced men in the field did not always follow the regulation format. Instead, one experienced officer wrote that, "at drill our maneuvers were chiefly confined to line marching, echelon movements, and formation of the square in every possible way". But still, that drill was exceptionally strict, as "if a man coughed in the ranks, he was punished; if the sling of the firelock, for an instant, left the hollow of the shoulder when it should not, he was punished; and if he moved his knapsack when standing at ease, he was punished". ${ }^{281}$

While these measures sound quite harsh to the modern civilian ear, it should be again stressed that these approving comments were made by an officer of the battalion, not the enlisted men

\footnotetext{
${ }^{278}$ Great Britain, Army, Rules and Regulations, 58.

${ }^{279}$ Lt. William Grattan, Adventures, 87.

${ }^{280}$ Great Britain, Army, Rules and Regulations, 152.

${ }^{281}$ Lt. William Grattan, Adventures, 87-88.
} 
who had to spend untold hours under such stress. Still, the methods used by British officers and NCOs in 1815 were not very different from those used by armies from ancient Rome to modern times. ${ }^{282}$

As the Anglo-Allied army waited for the Campaign of 1815 to open, the British infantry drilled intensively. Ensign Edward Macready of the $1 / 30^{\text {th }}$ Foot was billeted at Soignies, where "we were drilled out of all patience, and, like the soldiers of ancient Rome, I longed for war as a respite from fatigue". ${ }^{283}$ The British infantry trained intensively on the tactics that they knew were the most important to success on the battlefield. Basic training gave the soldier the fundamental skills of his profession, and the company, battalion, and brigade sized exercises gave both the enlisted men and their officers the advanced training needed for combat. ${ }^{284}$

The benefits of all that drill were numerous, and the officers were aware of the importance of an efficiently drilled battalion. When the $51^{\text {st }}$ Foot botched their maneuvers during a field day in England, they were dressed down,

until the Colonel was quite exhausted. He then dismissed us saying 'a bird that can sing and won't, must be made sing.' An order appeared directly after that convinced us he was not joking. It was for four hour extra drill per day, for a month." 285

Long drill gave men greater endurance. For example, the "severely drilled" $88^{\text {th }}$ Foot, the Connaught Rangers, "never had the appearance of being fatigued upon a march; and when they halted, you did not see them thrusting their firelocks against their packs to support them."286 While speed and precision of maneuver were welcome side-effects of a well-

\footnotetext{
${ }^{282}$ Richard Holmes, Acts of War, 50-52.

${ }^{283}$ Ensign Edward Macready, 1/30 "th "On a Part of Captain Siborne's History of the Waterloo Campaign”, by an Officer of the $5^{\text {th }}$ British Brigade [Major Edward Macready, $30^{\text {th }}$ Foot] (Colburn's United Service Magazine, 1845, Part I)

284 J. A. Houlding, Fit for Service, 276-277

285 Private Wheeler, Letters, 36.

${ }^{286}$ Lieutenant William Grattan, Adventures, 87.
} 
drilled battalion, the primary goals of drill were discipline, cohesion and control. Young officers were enjoined to

remember that their business when ordered to charge or fire in advancing should be confined to their men: to see that they level well and low; and that they move collectively and steady; and when commanded to push forward, that nothing like hurry or confusion appear amongst them. ${ }^{287}$

Drill was seen as critical to success in battle. Endurance, speed, and precision were elements of that success, but the essence of drill gave officers control of their men no matter what the circumstances.

Experience played a crucial role in combat. John Lynn divides experience into three categories: the experience of the commanders, the experience of recent failure or success of tactics in the field, and the experience that the men had accumulated during their army careers. ${ }^{288}$

Throughout the Revolutionary and Napoleonic wars the experience of British army commanders was constantly an issue. The purchase system that allowed junior officers to be rapidly promoted over more experienced officers showed that the British army valued loyalty in its officers more than it valued the experience that those officers accumulated during their careers. Despite attempts to reform the system, as late as 1809 an officer could rise to the rank of Lt. Colonel after only eight years of service. ${ }^{289}$

J. A. Houlding argues that the influence of purchase is overstated, and that the actual level of officers' experience was much higher than usually thought. ${ }^{290}$ Houlding's studies are based on surveys of numerous British regiments throughout the period 1715-1795. One of Houlding's criteria is the period that the average officer held a given rank, and many of his

\footnotetext{
${ }^{287}$ Charles James, The Regimental Companion, vol. I, 168.

${ }^{288}$ John Lynn, Bayonets of the Republic, 37.

${ }^{289}$ Phillip Haythornthwaite, Armies, 32.
} 
results reflect a much longer period of time in rank than those assembled for this paper. One explanation for the difference was that the higher rates of attrition encountered in the Revolutionary and Napoleonic Wars so depleted the ranks of the British officer corps that it caused a significant shift in the level of experience.

\section{Major Captain Lieutenant Ensign}

$\begin{array}{lrccc}\text { Houlding } 1793 \text { avg. } & 6.0 & 8.0 & 5.5 & 3.0 \\ 1815 \text { sample avg. } & .7 & 3.6 & 3.4 & 1.2 \\ \text { Inniskilling avg. } & & 8.4 & 7.1 & 1.4\end{array}$

While the level of experience in rank in the $1 / 27^{\text {th }}$ is commensurate with the rates seen in 1793, there is a discernable drop in overall experience levels seen between the armies of 1793 and 1815.

A detailed sample of officers' time in rank has been complied for five battalions who served at Waterloo: the Inniskillings, the other two battalions of their brigade, and two Guards regiments. $^{291}$ The numbers reflect the extensive experience of the Inniskilling officers, as the vitally important company officers, both captains and lieutenants, averaged more than seven years of experience in their roles.

The amount of time in rank is exceptionally low in the Guards regiments, which is a direct indictment of the purchase system. It is evident that wealthy, ambitious men flocked to the Guards to climb both the social and military ladders simultaneously, with a corresponding drop in the experience level of the officers directing some of Britain's finest soldiers.

\footnotetext{
${ }^{290}$ J. A. Houlding, Fit for Service, 99-116.

${ }^{291}$ Data drawn from Charles Dalton, Waterloo Roll Call.
} 
Table 18.

Years of Experience in rank, by rank, by Regiment

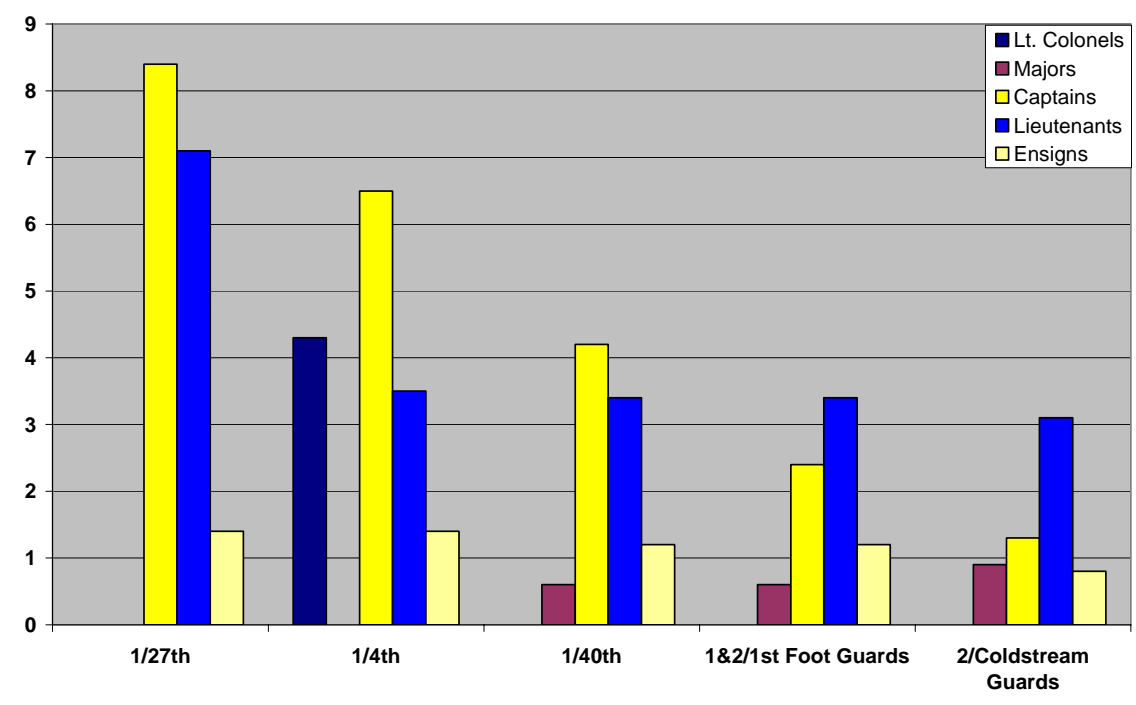

Most of the men of the British army had positive experience with their tactics, and the cumulative experience that they had gained during their army careers was a great advantage as well. Of the sixteen British line infantry battalions at Waterloo thirteen had fought in Spain. Of the three who had not served in Spain one had been in India, but the other two were wholly new to combat. One, the $3 / 14^{\text {th }}$ Foot, was composed of mere boys; thirteen of its officers and 300 of its 600 enlisted men were eighteen or younger. ${ }^{294}$

Many British line regiments had a long history that had given their men great opportunity to gain experience. The $1^{\text {st }}$ Foot was officially known as the Royal Scots, but owing to a regimental history going back to 1633 they were unofficially known as "Pontius Pilate's Bodyguards". ${ }^{295}$ A long regimental history did not guarantee that the men in the ranks were of great experience, but the war in the Peninsula had ended only a year before Waterloo. Due to the unlimited term of service that held many of the army's veterans in the

\footnotetext{
${ }^{294}$ Mark Adkin, Waterloo Companion, 176-177

295 Andrew Carew, How the Regiments got their Nicknames, 22.
} 
ranks, at Waterloo the British infantry was of exceptional experience, as the case of the Inniskillings can demonstrate.

During the campaign of 1815 the Inniskillings were a mix of new and experienced soldiers, but there were a surprising number of veterans. The experience level of the two hundred and eighty men who were drafted into the first battalion from the second is problematic. Those men are not a part of the records of the first battalion, and thus beyond the scope of the records consulted for this paper, but Lt. Charles Crowe of the second battalion left some clues regarding their make-up. The first battalion took their pick of the second battalion men when making their draft; when the third battalion came in from America weeks after Waterloo they too took a draft from the second battalion. That second draft "cleared off every drill squad to whom I had given arms. Many of them had not fired off a musket." 296 The second battalion had served well in Spain, and doubtless many of the men who were to serve with the first battalion at Waterloo were very experienced soldiers. ${ }^{297}$

\section{Table 19.}

Age at Waterloo

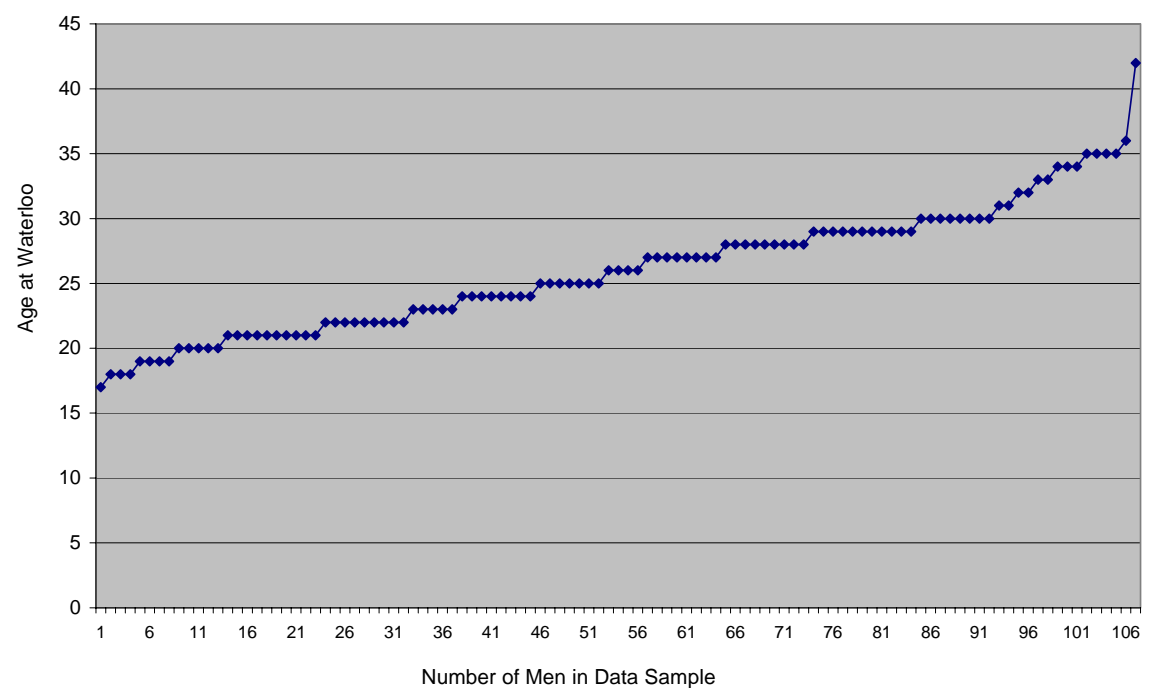

${ }^{296}$ Lt. Charles Drewe, Memoirs, 33. 
The core of the first battalion men were experienced veterans. As seen in figures 19 and 20, the average soldier of the battalion was twenty-six years old, and had seven years of experience. These men were in the prime of their lives, and the average length of service would have seen them through years of tough fighting against the French in Spain and southern France. While there were men in the ranks new to battle, the experience level of both the first battalion men and the men drafted from the second battalion was doubtless a major contributor to the steadiness of the Inniskillings at Waterloo.

Table 20.

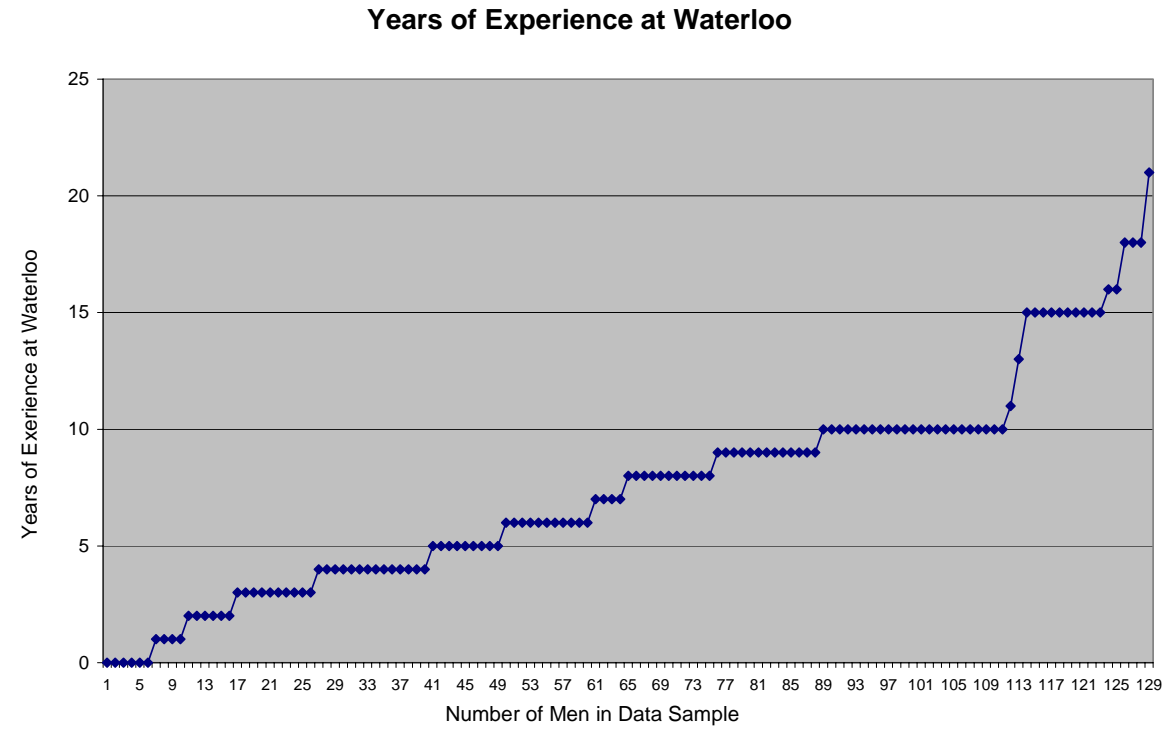

The tactical system employed by the British army was highly effective. It trained soldiers to handle their weapons and maneuver according to a doctrine that differed from the manual, but was proven successful in years of war. An essential benefit of the tactical system employed by the British army was its impact on unit cohesion. The tactical system depended on cohesion to function and was designed in part to enhance that cohesion. While some gaps in the records leave open the specific history of the Inniskillings' training and weapons,

${ }^{297}$ Park \& Nafziger, The British Military, 96. 
enough is known of their tactics and experience to conclude that the $1 / 27^{\text {th }}$ was an extremely capable battalion.

\section{Administrative System}

The administrative system behind the Inniskillings was the network of government agencies and policies that put men in the field. Those government agencies and policies recruited men, controlled their family lives, and provided equipment, food and drink, and medical services.

British recruitment policies were challenged, and indeed the nature of war was altered, by the levée en masse initiated by the revolutionary government of France in 1793. During the Revolutionary wars the comparatively small professional armies that served the European monarchies of the $18^{\text {th }}$ century were suddenly faced by massive French armies of untrained but enthusiastic soldiers. ${ }^{298}$ Beyond its political and societal implications, the levée en masse forced every nation of Europe to raise increasingly large armies to contend with the French.

Frederick the Great's Battle of Lobositz in 1756 involved just 62,000 men; by 1812 Napoleon's Battle of Leipzig was waged by armies totaling 560,000. ${ }^{299}$ The new form of warfare required far greater numbers of men than European war had ever seen. To meet this demand for manpower various drafts and levees were instituted across Europe, but in Britain the army continued to be manned solely by volunteers.

The recruitment of the British army during the Revolutionary and Napoleonic Wars is a topic worthy of extensive study, but a concise review is sufficient here. There were several different methods used to raise recruits in Britain. The most common was "beating" for recruits, a practice in which an officer and a small party of NCOs and drummers (hence the

\footnotetext{
${ }^{298}$ John Lynn, Bayonets, 55-57.

${ }^{299}$ David Chandler, Campaigns of Napoleon, 1120.
} 
"beating") would travel to likely recruiting grounds such as towns, villages, and fairs. ${ }^{300}$ The recruiting party would be dressed in their finest uniforms and would be generous with food and drink for their potential recruits. Recruiting posters promised "luxurious living, an hospitable table and capacious bowl of punch" while tales of glory and adventure from the soldiers were meant to entice the young and the bored. ${ }^{302}$ The recruiting parties were especially active in winter, after the harvest was in, when there was little farm work to be had, and a poor man's need might be keenest. ${ }^{303}$

The recruiter's enticements were reinforced by an enlistment bounty that varied according to the government's desperation. The traditional "King's shilling" was a myth, as by 1800 the bounty for line infantry totaled $10 £ 10$ s, to be paid as follows: $:^{304}$

\begin{tabular}{|c|}
\hline When attested: \\
\hline $\begin{array}{l}\text { On intermediate approval: } \\
\text { On final anproval. }\end{array}$ \\
\hline
\end{tabular}

These recruiting methods were directed towards the general male population, but also towards the militia, fencible, and yeomanry units that constituted much of Britain's home defense forces. The regular army constantly competed with the home units for the best recruits, and often the government offered extra bounties and options regarding length of service to entice men to leave Britain for foreign service. The recruiters' dealings with the militia were not always gentle; Sergeant Thomas Morris of the $2 / 73^{\text {rd }}$ wrote:

The Militia Regiments would be drawn up in Line, and the Officers, or N.C.O.'s, from the regiments requiring Volunteers, would give a glowing description of their regiments, describing the victories they had gained and the honours they had acquired, and conclude by offering, as a bounty, to volunteers for life $£ 14$, to volunteers for the limited period of service of seven years, $£ 11$. If these inducements were not effectual in getting men, then coercive measures were adopted, heavy and long drills, and field exercises

\footnotetext{
${ }^{300}$ Charles James, Regimental Companion, 409-416.

${ }^{302}$ Recruiting poster for $7^{\text {th }}$ Light Dragoons, in Haythornthwaite, Armies, 46.

${ }^{303}$ J. A. Houlding, Fit for Service, 116.

${ }^{304}$ Charles James, Regimental Companion Vol. I, 412.
} 
were forced on them; which were so oppressive, that to escape them, the men would embrace the alternative and join the regulars. ${ }^{305}$

Another source of recruits was the jails. Both debtors' prisons and criminal courts offered men an opportunity to enlist rather than face prison. Further, laws were passed that entitled magistrates to send the army any "able-bodied idle, and disorderly persons who cannot upon examination prove themselves to exercise and industriously follow some lawful trade or employment". 306

Despite the desperate need for men, there were standards in place regarding the quality of potential recruits:

The standard for men raised for the heavy cavalry, is to be five feet seven inches, and for the light cavalry and infantry five feet five inches; but no recruits are to be taken even of those sizes, who exceed thirty five years of age, or who are not stout and well made. Lads, between sixteen and eighteen years of age, who are well limbed and likely to grow, may be taken as low as five feet six inches for the heavy cavalry, and five feet four inches for the light cavalry and infantry.

The standards for the life guards, is six feet in time of peace, and five feet ten inches during war. ${ }^{307}$

Further, the recruit's oath ensured that he was "not troubled by fits, and am no ways disabled, by lameness, or otherwise; but have the perfect use of my limbs; that I am not an apprentice; and that I do not belong to the militia, or any other regiment, or to his majesty's Navy, or marines". ${ }^{308}$ It is interesting that there was no basic requirement of mental capacity for recruits; doubtless some officers in the British army would have echoed Frederick the Great's comment, "if my soldiers began to think, not one would remain in the ranks". 309 There is considerable information regarding the recruitment of the Inniskillings. Certainly some may have been recruited from the Irish militia and yeomanry regiments,

\footnotetext{
${ }^{305}$ Sergeant Thomas Morris, Recollections (London: Bells, 1845), 46.

${ }^{306} 18$ Geo. II c. 12, quoted in Houlding, Fit for Service, 118.

${ }^{307}$ Charles James, Regimental Companion Vol I, 413.

308 ibid., 418.

${ }^{309}$ Frederick the Great, quoted in Houlding, Fit for Service, v.
} 
though the quality of those recruits would have been poor. The discipline in the Irish militia was notoriously bad. General Sir John Abercromby, who was appointed to command the Irish home defense forces in 1797 , wrote that his command was "in a state of licentiousness which render it formidable to everyone but the enemy". ${ }^{310}$ There were no fencible troops raised in Ireland, but yeomanry troops also served as a potential source of recruits for the regular army. The yeomanry was essentially a private army raised to enforce the rule of the Protestant Ascendancy in Ireland, and the "government naively considered that zeal would compensate for military discipline, but in practice the enthusiasm was often for sectarian score-settling rather than disinterested public service." ${ }^{311}$ Recruits from the Irish militia and yeomanry units would have had some rudimentary training in military life, but bending such men to the strict rules of regular army discipline would certainly have posed a problem for the officers of the 27 th.

There are two elements, however, in the pay rosters that hint that there were few militiamen in the ranks of the $1 / 27^{\text {th }}$ at Waterloo. As mentioned above, militiamen were usually offered an option of a seven-year term of enlistment, but every man in the $1 / 27^{\text {th }}$ at Waterloo had enlisted for unlimited service. Secondly, the age of enlistment for most of the men in the $1 / 27^{\text {th }}$ was comparatively young, suggesting that many of the regiment's men went from civilian life straight into the regular army.

\footnotetext{
${ }^{310}$ General Sir Ralph Abercromby, quoted in Thomas Pakenham, Year of Liberty, 51.

311 Allan Blackstock, Ascendancy Army: The Irish Yeomanry, 1796-1834 (Dublin: Four Courts Press, 1998$), 143$.
} 
Table 21.

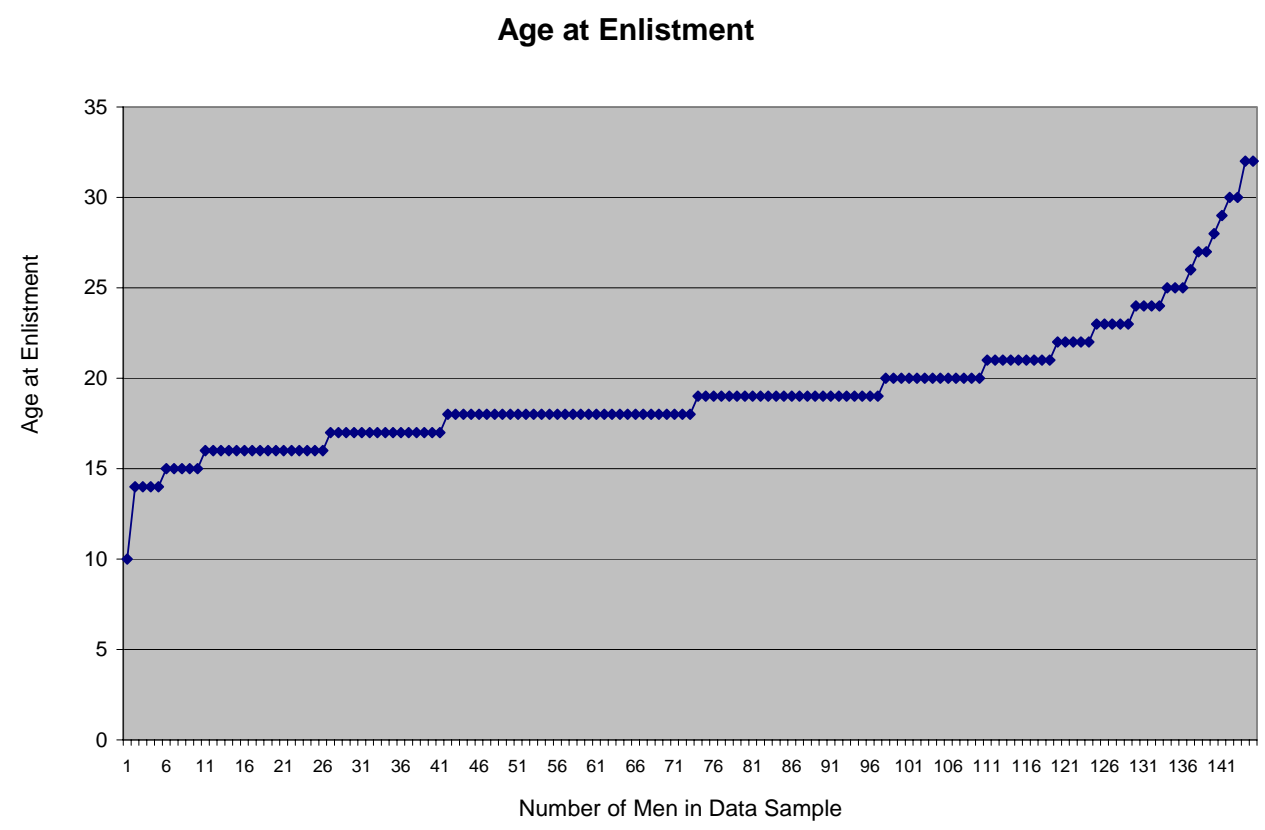

Further details of the recruitment process can be gleaned from the recruit rosters maintained by the $27^{\text {th }}$ Foot. ${ }^{312}$ The recruit rosters reveal the place and date of attestation, the period of service, and the name of the officer or NCO who attested the recruit. The records do occasionally mention service in a militia unit; for example, Drum Major Richard Creaton of Aberdeen volunteered into the $27^{\text {th }}$ Foot from the Perth Militia on 28 April, 1815, for unlimited service, attested by Lieutenant Maguire. He did not serve at Waterloo.

Another instance that certainly appears to reflect a volunteer from the militia is found in the post-Waterloo pay roster of September to December 1815 when Thomas Harris and Vincent Bertuni joined the battalion. Harris seems a regular recruit: he was 20 years old, enlisted for unlimited service, and was made a private. Bertuni, though, was probably a volunteer from the militia. Born in Rome, Bertuni was a rare Italian in an Irish regiment. When he came to the Inniskillings, he was 36 years old, enlisted for only seven years of

\footnotetext{
${ }^{312}$ United Kingdom War Office, Description Book, $27^{\text {th }}$ Foot.
} 
service, and was entered as a sergeant. Bertuni's name also appears in the recruitment rosters, which reflect that he was made a corporal in 1810 , a sergeant in 1813 , but does not mention in what corps he served prior to coming to the $1 / 27^{\text {th }}$. In civilian life he was a musician, and he, like Drum Major Creaton, may have been enticed from the militia for his musical talent.

A handful of men were enlisted while the battalion was on foreign service. Armourer Francisco Papa of Mantua, Italy, a gunsmith in civilian life, was doubtless a fine catch for the first battalion when he was attested by Adjutant Tayler in Palermo in 1812. It was difficult to entice skilled craftsmen such as Papa into the army, as the pay and prestige of a civilian gunsmith far out-weighed the charms of army life. Papa's motivations for joining the British army are unknown, but his age at enlistment (he was only 19) hints that he had an unhappy apprenticeship to an Italian gun maker. Papa would miss Waterloo, as he was with the battalion staff in the mid-Atlantic. ${ }^{313}$

While the details regarding men such as Creaton, Bertuni, and Papa give insight into how some of the skilled positions in the $1 / 27^{\text {th }}$ were filled, the soldiers who filled the ranks at Waterloo were mostly Irishmen. This paper's section on national origin showed that the men of the $1 / 27^{\text {th }}$ were born in Ireland. At the risk of sounding repetitive, it is also necessary to prove that the men of the battalion were also recruited in Ireland. They would not truly be "Irish" soldiers if they had left their homes to be snapped up by recruiting parties in other parts of Ireland, or indeed in England. Beyond the concerns for the origins of the men it is also important to understand the recruiting territories of the Inniskilling regiment. Of the thousands of names on those records, the "attestation" details of one hundred eleven men can be traced to men who served in the first battalion on June $18,1815 .{ }^{314}$

\footnotetext{
${ }^{313}$ ibid.

314 ibid.
} 
Table 22 .

Where Attested, by percent

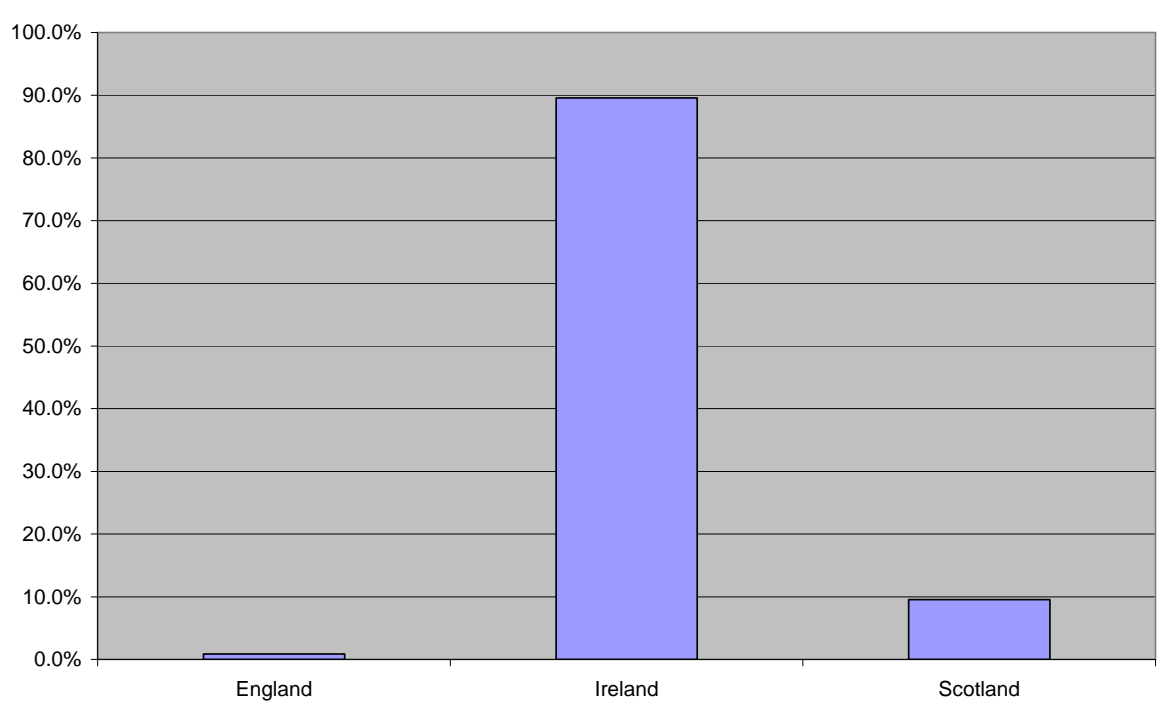

Based on the available records, ninety percent of the men who served in the $1 / 27^{\text {th }}$ at Waterloo were recruited in Ireland. Further, more than fifty percent of the men were recruited in Ulster.

Table 23 .

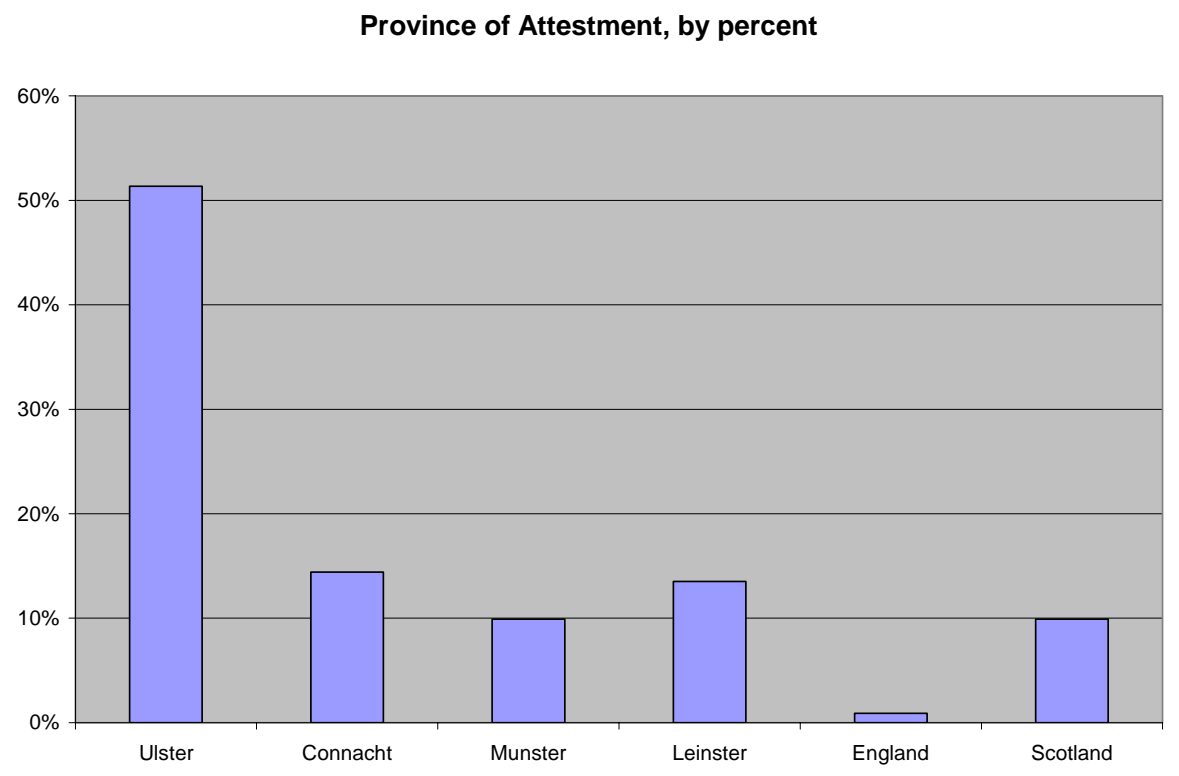


Table 25 .

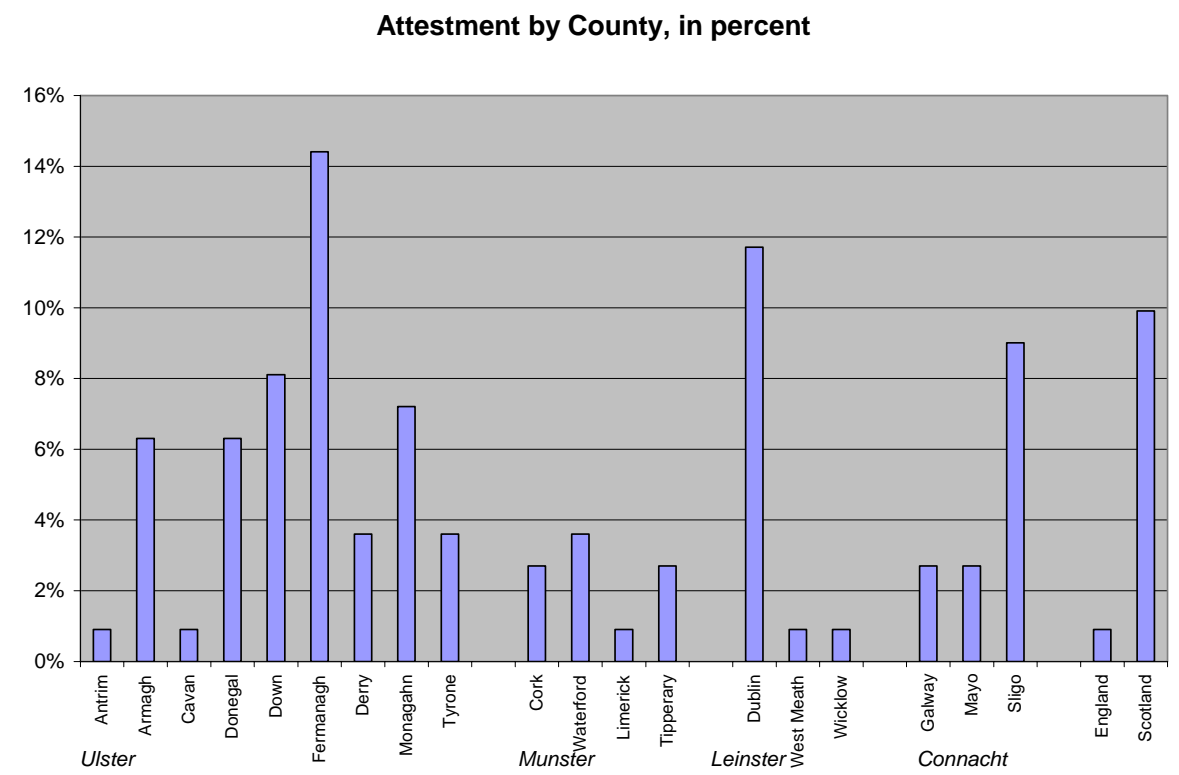

The $1 / 27^{\text {th }}$ at Waterloo was a rarity in the British army, in that their title truly denoted their origin. The Inniskilling Regiment really was the Inniskilling Regiment.

The Inniskillings recruited mainly in the larger towns of northern Ireland. Many men signed up in Enniskillen or the market towns that scattered across northern Ireland: Armagh, Ballyshannon, Clones, and Sligo. Recruiting parties also traveled to the cities of Dublin, Cork, and Waterford in the south. Some small towns in the south were visited by Inniskilling recruiters as well; Private John Hamilton was attested in Cootehill in County Cavan, and Drummer John Robinson was recruited in Thurles, County Tipperary.

As mentioned above, it was difficult to recruit skilled laborers, as military discipline and pay paled in comparison with the life of the typical skilled laborer. This difficulty can seen in the split of skilled to unskilled laborers in the $1 / 27^{\text {th }}$ at Waterloo.

Table 25 . 
Skilled vs. Unskilled Laborers, in percent

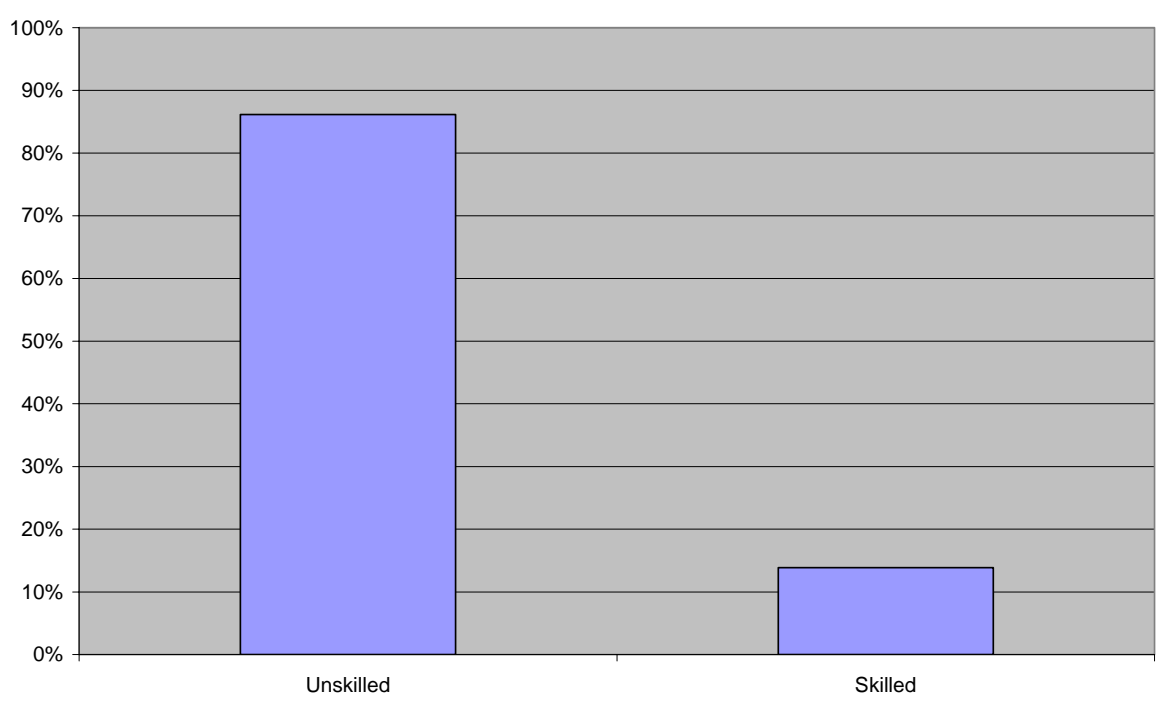

A review of the few skilled laborers who joined the army out of desperation is an interesting slice of $18^{\text {th }}$ century Ireland.

Table 26.

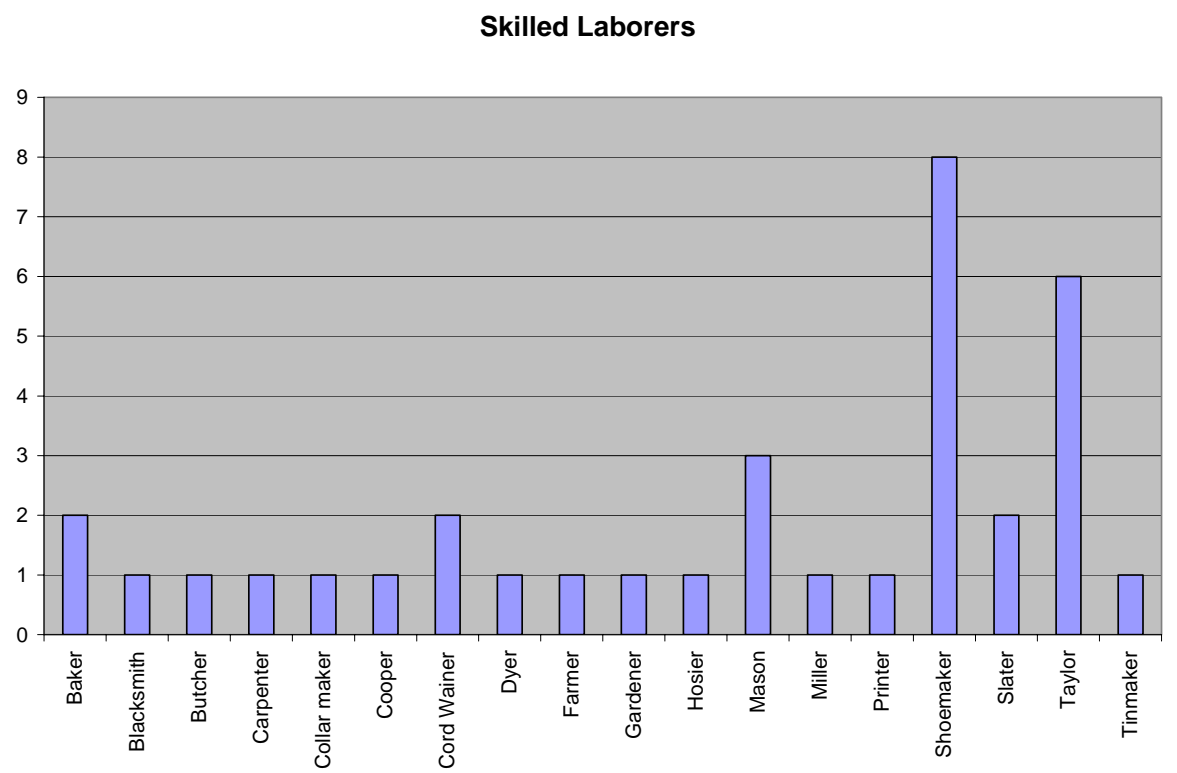

The unskilled laborers of the $1 / 27^{\text {th }}$ were almost exclusively farm laborers and weavers.

Table 27. 


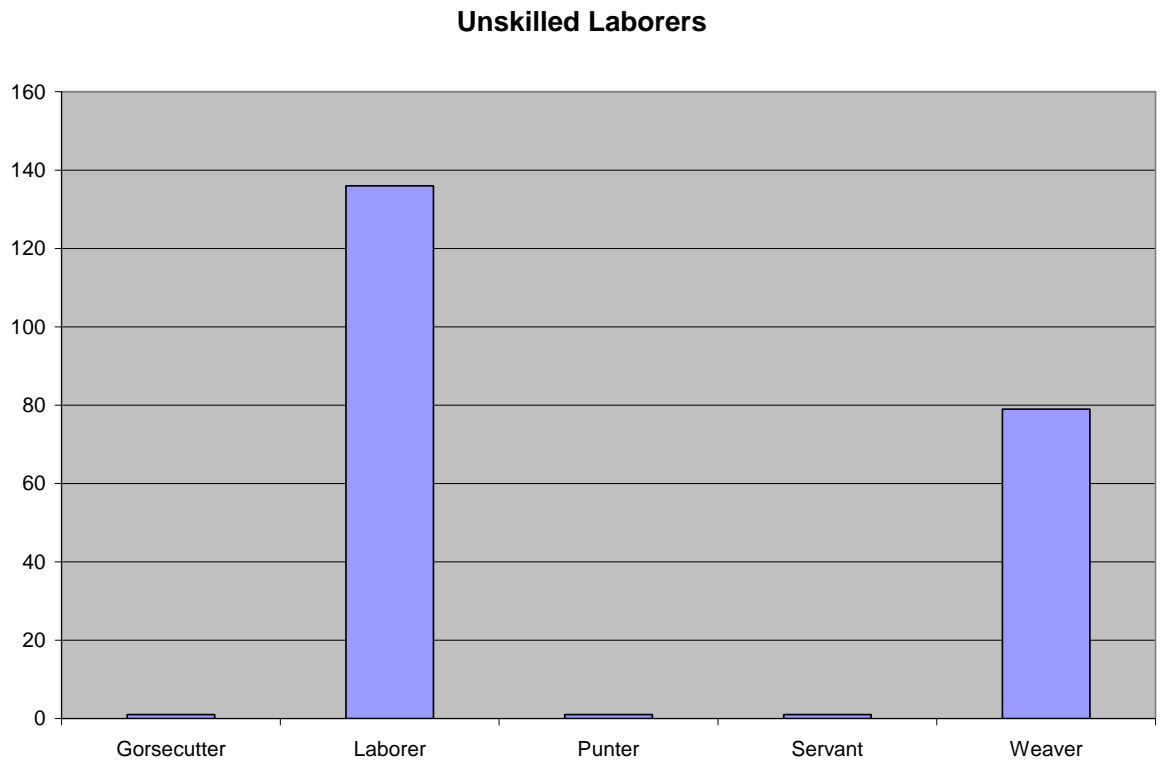

The primary difference between skilled and unskilled laborers was literacy; skilled laborers were much more likely to have at least rudimentary skills. In the case of the Inniskillings another difference between skilled and unskilled laborers as recruits was language. Farm laborers from isolated farms were more likely to speak only Irish.

The men who were recruited into the $27^{\text {th }}$ were young men, who naturally may have had interest in having a family. Indeed, many of the rank and file of the British army of the day were married with families, although official government policy discouraged marriage. The Army regulations of 1795 stipulated that "officers must explain to the men the many miseries that women are exposed to and by every sort of persuasion they must prevent their marrying if possible."315 The government acknowledged the miseries involved, but did nothing to alleviate them. Furthermore, a soldier typically needed his commanding officer's permission to marry. Any soldier who married without permission would suffer the consequences. An officers' guide stated that "no man who presumes to marry without leave

\footnotetext{
${ }^{315}$ Cited in R.G. Glover, Peninsular Preparation, 221.
} 
of his commanding officer, is to be allowed to mess, or sleep out of camp, or barracks; nor is he to have the same indulgences which good soldiers generally receive". ${ }^{316}$ Even if given permission, soldiers who did marry and have families had to live in the barracks in squalor, as no extra pay, rations, or quarters were allocated to married men. ${ }^{317}$

Some soldiers certainly heeded their officers' advice regarding marriage, but others preferred to stay single for their own reasons. Private Wheeler of the $51^{\text {st }}$ Foot wrote that

it might all be all very fine in its way and no doubt there are many sweets in having a pretty lovely young woman for a comrade, but then, I know from observation that there is an indefinite number of bitters attending it, a soldier should always be able to say when his cap is on, his family is covered, then he is free as air. ${ }^{318}$

When the troops were ordered to active service only a handful of women were allowed to follow the regiment; usually only three to five per company. The women who were to be considered for overseas service had to be on the battalion's Married Roll, be of good moral character, be willing to work for the men, and have no more than two children. ${ }^{319}$ Rolling dice or drawing lots decided who would remain in Britain, and who would travel with their husbands. The wives and children who were to be left behind were forced to return to their native parishes to await the return of the regiment, where the parish was responsible for their support. ${ }^{320}$

Once on campaign, unofficial wives, prostitutes, and various camp followers eventually joined the women and children who won the right to march with the regiment. These women had no official status and thus were not allowed to accompany their men at the close of the campaign. But whether on the Married Roll or not, the women who followed the army routinely clogged the roads, hindered discipline, and slowed the movement of the

\footnotetext{
${ }^{316}$ Charles James, Regimental Companion, 284.

${ }^{317}$ Phillip Haythornewaite, Armies, 155.

${ }^{318}$ Private William Wheeler, Letters, 188.

${ }^{319}$ Richard Holmes, Redcoat, 297.
} 
regiments. Senior officers often cursed their presence, and Wellington felt that "it is well known in all armies the Women are at least as bad, if not worse, than the men as Plunderers!"’321

Captain Cavalié Mercer, an observant if intolerant British artillery officer, portrayed soldiers' wives as coarse, but not without a nod toward their toughness. Observing an incident at the docks at Ostend as British troops disembarked for the campaign of 1815, he wrote of some sailors who were "amusing themselves with the bustling anxiety of a score of soldiers' wives, who, loaded with children or bundles, their ample grey or faded red cloaks flying out loosely behind them, struggled with an activity, perseverance, and volubility which seemed highly diverting to the mariners, many of whom, in broken English, were bantering these amazons, or exchanging coarse jokes with them; at which play however - the ladies being mostly from the Green Isle - the gentlemen came off second best." ${ }^{, 22}$.

Lieutenant Charles Crowe was Adjutant of the 2nd battalion of the Inniskillings, and was responsible for the embarkation of new men going to join the 3rd battalion. Crowe had at least some sympathy for the families of these young soldiers:

A very painful duty devolved to me, when embarking these raw soldiers. Most of them had brought young wives from Ireland. The War Office order granted only three wives per company. And the number actually on board the transports, according to the returns was already too great to allow many embarking. Sir John had to draw lots for every company. I was obliged to have a serjeant's guard at the approach of the jetty from whence the men descended into boats to row off to Spithead. I was deeply engaged at the head of the jetty when a shout of horror made me look to the rear. A lovely young woman with a baby in her arms, had forced through the guard, and was rushing with the frenzy of desperation to throw herself and babe into the boat below to her husband! She was not ten yards distant, but instantly I ran and grasped her in my arms and having given myself a rotary motion to check her impetus, the woman, baby and Adjutant were sprawled on the jetty! In this interval the boat had shoved off and the wretched lovely woman had no

\footnotetext{
${ }^{320}$ Phillip Haythornewaite, Armies, 127.

${ }^{321}$ Wellington, in Anthony Brett-James, Wellington at War, 164.

${ }^{322}$ Captain Cavalié Mercer, Journal, 15.
} 
alternative but to return to Ireland with the government allowance per mile, with her numerous and equally disconsolate companions. ${ }^{323}$

The pay rosters for the period of 11 May to 10 June 1815 reflect the disbursement of $8 £ 19 \mathrm{~s}$. for women and children to be sent home from the regiment. Many of the women who were separated from their husbands on the docks at Spithead were widowed six weeks after seeing their husbands sail across the Channel.

The British Quartermaster General and the Master General of Ordnance were responsible for issuing an extensive list of equipment to the British infantryman. While extensive regulations listed the quantity, quality, and timing of their issue, the actual equipment carried by the men in the field, as well as its condition, were often far different than regulations required.

All British line regiments wore the traditional red coat. Lace trim and distinctive facing colors distinguished each regiment. In the case of the Inniskillings, collars and cuffs were buff in color, and their white lace trim had narrow red and blue stripes. Trousers and gaiters were gray, and the leather cross belts and pack straps were white. A tall black leather shako was the standard headgear, fronted by a distinctive brass plate, decorative cords, and a small plume.

Most of the men of the line regiments wore a small red-over-white plume, though the men of the grenadier companies wore white plumes and tufted shoulder wings. Men of the light companies wore shoulder wings like the grenadiers, but with green plumes and cords.

Non-commissioned officers wore chevrons on their right sleeves: sergeants major and quartermaster sergeants wore four, sergeants wore three, and corporals wore two. The uniform as described paints a handsome picture. Reality, though, was far less perfect. Coats

\footnotetext{
${ }^{323}$ Lieutenant Charles Crowe, quoted in Martin Cassidy, Marching with Wellington (Barnsley, Yorkshire: Leo
} 
and trousers were often ill fitting, and as new issues were few and far between the older soldiers often wore very worn and patched uniforms. The red coats of new recruits often bled their dye, turning the white leatherwork a very unmilitary pink. The coats were made of heavy wool, and in summer campaigns they were very hot and far from waterproof. In the field the uniforms were usually filthy; there were few opportunities to clean up, and there were no spare changes of clothes. The shakos were often battered, and on campaign they were usually wrapped in a plain black oilskin cover. The shako had only a small brim in front, which was small comfort in bright sun or heavy rain. ${ }^{324}$

Other standard issue equipment included a pack, canteen, and haversack. Designed for functionality and low cost, this equipment was heavy and uncomfortable to carry. The pack was black leather over a wooden frame, the hard edges of which would dig into a man's back when loaded. ${ }^{325}$ The items borne by a typical infantryman of 1815 consisted of:

Musket and bayonet, 14lbs.

Pouch and sixty rounds, 6lbs.

Full canteen, 4 lbs.

Mess-tin, $1 \mathrm{lb}$.

Knapsack, 3 lbs.

Haversack, 2 lbs.

Blanket, 4 lbs.

Dress coat, 3 lbs.

Shako, plate, plume, and cords, $2 \mathrm{lbs}$.

White undress jacket, $1 / 2 \mathrm{lb}$.

Two shirts and three ruffles, $2 \frac{1}{2} \mathrm{lbs}$.

Two pairs shoes, $3 \mathrm{lbs}$.

Trousers, 2 lbs.

Gaiters, $1 / 4 \mathrm{lb}$.

Two pairs stockings, $1 \mathrm{lb}$.

Two tent pegs, $1 / 4 \mathrm{lb}$.

Pipe-clay, $1 \mathrm{lb}$.

Two days' bread, 3 lbs.

Two days' meat, $2 \mathrm{lbs}$.

Personal items, 3 lbs.

Pen, Ink, and Paper

Cooper, 2003), 139.

${ }^{324}$ Otto Von Pivka, Armies of the Napoleonic Era, 136-138.

${ }^{325}$ Mark Adkin, The Waterloo Companion, 177. 
Three brushes

Box of blacking

Razor

Soap box and strap ${ }^{326}$

In addition, the soldier would take his turn carrying the squad camp kettle, (4 lbs.) one of

which was issued for every six men, or a billhook, $(6 \mathrm{lbs}$.) one of which was issued to every ten men for cutting brush and firewood. ${ }^{327}$ Even on the days when the soldier was lucky enough not to be carrying the squad kettle or billhook, he was still loaded down with more than fifty pounds of weapons and equipment, which Private William Wheeler believed was "load enough for a donkey." 328 The load may have been unpleasant, but it was similar to the load carried by French infantry of the day. ${ }^{329}$

Officers of British regiments wore uniforms very similar in style to the other ranks, as they typically wore the red coat with its distinctive facing colors, shako, and gray trousers. But as officers bought their own uniforms the quality was normally much better than the government issue; the scarlet of an officer's coat was distinctly brighter than the various shades of brick red to rusty brown seen in the ranks. ${ }^{330}$ That quality was not inexpensive; in 1813 an officer could expect to pay $£ 316$ s for his shako, and $£ 516$ s for a uniform coat. ${ }^{331}$ An officer's distinctions of rank were quite understated: company officers had no epaulettes, as they were reserved solely for senior officers. A red sash tied around the waist and a silver gorget at the neck were the officers' only marks of rank in the companies, though of course the officers carried no pack. Their only burden in the field was a light sword, its scabbard, and a white sword belt over the right shoulder.

\footnotetext{
${ }^{326}$ Anonymous, The Little Bombardier and Pocket Gunner, (London: T. Egerton, 1801), 112.

${ }^{327}$ Phillip Haythornewaite, Armies, 85, and S.G.P. Ward, Wellington's Headquarters (Oxford: Oxford University Press, 1957), 200-201.

${ }^{328}$ Private William Wheeler, Letters, 48.

${ }^{329}$ Colonel John R. Elting, Swords Around a Throne (New York: The Free Press, 1988), 217.

${ }^{330}$ Phillip Haythornewaite, Armies, 83.

${ }^{331}$ Richard Holmes, Redcoat, 186.
} 
All officers were mounted while on the march, though in battle the company officers dismounted to take their places in the ranks. Only a battalion's Lt. Colonel and Major were mounted in action. Officers had to supply their own horses, though if one was lost while in the field the owner would receive (at least, partial) compensation. Most officers had more than one horse, if they could afford it. This is evident through the regulation fodder allowances: a captain, for instance, was allotted three rations of fodder. ${ }^{332}$

While the officers had better uniforms, lighter loads, and often traveled on horseback, on campaign their appearance often suffered as much as the enlisted men. Rain, heat, and mud did not discriminate between ranks. The campaign of 1815 was destined to be a wet one and one officer, at least, had the good sense to include an umbrella in his kit, "which, by the way, had afforded some merriment" to his men. ${ }^{333}$

As with so many aspects of the lives of British soldiers of the Napoleonic era, food and drink rations were heavily regulated, and, once again, the consistent application of those regulations often wavered in practice. The official daily food ration for an enlisted man consisted of:

$1 \frac{1}{2}$ lbs. Bread

$1 \mathrm{lb}$. Beef or $1 / 2 \mathrm{lb}$. pork

$1 / 4$ pint Pease

$1 \mathrm{oz}$. Butter or cheese

1 oz. Rice ${ }^{334}$

When the regiment was in barracks the logistics system of the day managed to keep the men fed, and while in billets the battalion adjutant paid local innkeepers to provide food. But the focus of this thesis is on men at war, when even a short campaign could stretch an

\footnotetext{
${ }^{332}$ S.J. Park \& G.F. Nafziger, The British Military, 30.

333 Captain Cavalié Mercer, Journal, 157.

${ }^{334}$ Anonymous, The Little Bombardier and Pocket Gunner, 182.
} 
army's logistics system beyond its limits. A lieutenant of the Inniskillings in Spain wrote that "we ought to have drawn rations for our men yesterday, but none were to be procured. And here the exhausted commissariat stores afforded only $40 \mathrm{lbs}$. of bread and $40 \mathrm{lbs}$. of meat, not a third of what we required. We three officers declined drawing anything for ourselves, or our servants, that what we could obtain was served out to the party. Nevertheless it was but too evident that our men were very dissatisfied." ${ }^{, 335}$

Another part of the British soldiers' daily ration was alcohol. Each enlisted man was entitled to a third of a pint of gin or rum daily. ${ }^{336}$ This official allowance could also be supplemented from alcohol available from the sutlers that followed the army everywhere. Private Wheeler of the 51st Foot found brandy and gin available in Mont St. Jean on the night of June $17^{\text {th }}$, writing that as "night came on we were wet to the skin, but having plenty of liquor were, to use an expression of one of my old comrades, "wet and comfortable.",337

As evidenced by the soldier's equipment list (above), the typical infantryman's load included two days' bread and meat. Replenishment thereafter was dependent on the Commissariat Corps and the Royal Waggon Train. The commissariats, who wore militarystyle uniforms, were in fact civilian employees of the Treasury. They were faced with the enormously difficult task of supplying tens of thousands of men along terrible roads with limited funds and resources. The commissariats worked with the Royal Waggon Train and local civilian contractors to carry the supplies.

The commissariat, the Royal Waggon Train, and their civilian drivers all had very poor reputations within the army. Most of those impressions were made during the long campaign in the barren hills of Spain, though the logistics services did little to rescue their sullied reputations during the 1815 campaign. The Waterloo campaign was a very short one,

\footnotetext{
${ }^{335}$ Lt. Crowe, Memoirs, 16.

${ }^{336}$ Mark Adkin, Waterloo Companion, 176.
} 
made in country of great abundance, but the weather was terrible. The roads soon turned to thick mud, laden wagons quickly mired, and the commissariats claimed that the civilian contractors abandoned their loads at the first sign of danger. All sources agree that no rations at all reached the Allied army on the two days of greatest action, the $17^{\text {th }}$ or 18 th of June. Wellington was so dissatisfied that he ordered that the Waterloo Medal was to be denied to all of those involved in the supply services. ${ }^{338}$

If the enlisted men suffered by the lack of efficient supply, the officers usually fared much better, as they typically laid in private stocks of provisions. But the sudden beginning of the Waterloo campaign found many officers' larders unprepared: the sudden call to march left at one officer with a small slice of meat-pie as his only fare for three days. ${ }^{339}$ If private stocks or funds grew low, officers were allowed the same rations as the other ranks. In fact, officers in the field were allowed additional rations for their servants. While liable for their civilian servants' wages, a subaltern was allocated one extra ration to feed them, a captain five, and a major seven. ${ }^{340}$

The medical care of the soldiers were not ignored; regulations dictated that each battalion in the British army of the Napoleonic era be assigned one surgeon and two assistant surgeons. These men should not be confused with physicians of the day, who were well educated medical professionals, and who carried significant social status. Army surgeons had limited training, and the King's Regulations declared that they were not to "have any Claim to Military Rank in Our Army". ${ }^{341}$ Worse, assistant surgeons often had no

\footnotetext{
${ }^{337}$ Private William Wheeler, Letters, 198.

${ }^{338}$ Mark Adkin, Waterloo, 325.

339 Captain Cavalié Mercer, Journal, 140.

${ }^{340}$ Phillip Haythornewaite, Armies, 125

${ }^{341}$ Great Britain, Army, Regulations for...Regimental Surgeons, 7.
} 
qualifications at all, as "only the most passing acquaintance with medical matters was needed for a man to be appointed as assistant surgeon, via family connections or patronage." ${ }^{342}$

Regimental surgeons were paid as captains and assistant surgeons as lieutenants, and despite their non-military status the surgeons were considered members of the battalion's officer corps. Like the line officers, the battalion medical staff was mounted, and they also had a mule to carry their supplies. ${ }^{343}$ The surgeons wore a uniform that combined their separate status with their military identity: a unique single-breasted red coat with facings of the regimental color. They wore the traditional infantry shako, but with a distinctive black plume. $^{344}$

In action the surgeons took up a position to the rear of the regiment, far enough away to be out of immediate danger but close enough for the wounded to reach the surgeons as quickly as possible. Usually one Assistant Surgeon would be detailed to remain with the battalion to administer first aid, while the rest of the medical staff would combine with others from the same brigade to establish an efficient aid post further to the rear. ${ }^{345}$ The comparative safety of the regimental aid posts is confirmed by a review of the Waterloo casualty returns. Of the sixty-eight medical men in the ranks of British infantry battalions, only the unfortunate Assistant Surgeon John Stewart of the $92^{\text {nd }}$ Highlanders was wounded. ${ }^{346}$

At Waterloo the Inniskillings lacked a Surgeon, and faced the battle with only two Assistant Surgeons in the ranks. The Inniskillings were unfortunate in their lack of medical staff, as only three of the twenty-five British infantry battalions at Waterloo did not have a surgeon present. Assistant Surgeons Gerald Fitzgerald and Thomas Mostyn both seem,

\footnotetext{
${ }^{342}$ Phillip Haythornthwaite, Armies, 133.

343 ibid., 59.

${ }^{344}$ Mark Adkin, 316.

345 ibid., 318.
} 
however, to have had qualifications beyond those of the typical Assistant Surgeon. Both men had been Assistant Surgeons for four years, and only months after Waterloo Fitzgerald's skills earned him a promotion to Surgeon of the 69th Foot. Mostyn was exceptionally experienced, having begun his service as a Hospital Assistant in the Peninsula, and being awarded the Peninsula medal with eight clasps. ${ }^{347}$ This combination of skill and experience was a partial compensation for the lack of a regimental surgeon, but two men would be singularly incapable of handling the hundreds of casualties experienced by the Inniskillings at Waterloo.

Regimental Surgeons were supplied with a vast selection of medicines, and were responsible for a complete yearly return regarding their use. The list of medicines has more than one hundred twenty items, listed by their Latin names. ${ }^{348}$ Some of the medicines, such as Tincture of Opium, sound familiar to a modern physician, but most were of doubtful efficacy. ${ }^{349}$ Useful or not, the medicines in the bulky chests of the regimental Medicamenta were numerous and represented a substantial investment in the army in the health of their soldiers.

Both the Surgeons and the Assistant Surgeons had to provide their own medical instruments. The list of the instruments required of the Surgeons listed thirty-two separate line items, including an amputating saw, twenty-four needles, bullet forceps, six tourniquets, a trephine, and "one strong knippers for bones". The list of instruments for Assistant Surgeons is much less extensive, requiring only thirteen different items, such as scissors, needles, and probes. ${ }^{350}$ How the Inniskillings' two Assistant Surgeons were equipped is

\footnotetext{
${ }^{346}$ Charles Dalton, Waterloo Roll Call, 194.

347 ibid., 134.

${ }^{348}$ Great Britain, Army, Regulations for...Regimental Surgeons, 29-40.

${ }^{349}$ Conversation with Dr. Mark Wurster, M.D., August 21, 2006.

${ }^{350}$ Great Britain, Army, Regulations for...Regimental Surgeons, 24.
} 
unknown, but as Gerald Fitzgerald was to be a Surgeon in the months after Waterloo it may be logical to assume that he possessed an equivalent set of instruments.

All medical care in the early $19^{\text {th }}$ century was very limited in capability, and the battlefield medicine of that period was primitive at best. The limited efficacy of the medical skills, medicines, and instruments available to a wounded soldier made survival of even minor wounds problematic at best.

While the handling of the wounded Inniskillings will never be known, some reasonable estimates can be made. Many of the men who were only lightly wounded would have stayed in the ranks. The strong group cohesion of the battalion would have prompted most of the lightly wounded to wrap a bit of shirt around the wound and stay with their comrades. Doubtless some men took the opportunity offered by a slight wound to leave the ranks and have their wounds dressed, though their return may have been doubtful. The walking wounded staggered to the rear to search out the surgeons. Badly wounded men would have been dragged into the middle of the square. The badly wounded could be carried back to the surgeons, but orders prohibited healthy men from aiding the wounded to the rear. While those orders were often ignored, at Waterloo the stationary nature of the square and the close proximity of the officers would have prevented many healthy men from helping the wounded. The $30^{\text {th }}$ Foot, perhaps two hundred yards to the east of the $27^{\text {th }}$, "were charged so furiously that we could scarcely send our wounded officers to the rear and much less the men." ${ }^{351}$ Those comments aid in understanding how the wounded were handled, but also reflects the marked class distinctions in the prioritization of casualty evacuations.

Wounded officers of the $1 / 27^{\text {th }}$ did not always have to rely on their men to evacuate them. The wife of Captain John Tucker, who was also the sister of Ensign Thomas Smith,

\footnotetext{
${ }^{351}$ Ensign Robert Howard, quoted in John Keegan, The Face of Battle, 173.
} 
had accompanied the regiment to Waterloo, and was staying with the regimental baggage not far from the battlefield. When she heard that her husband had been wounded,

she managed to make her way to the regiment, and assisted her husband, who had been wounded in the leg, to a place of safety. Afterwards hearing that her brother was wounded, she a second time managed to reach what was left of that gallant regiment, and succeeded in performing the same kind office for her brother. ${ }^{352}$

Whether they were evacuated during the battle or had to suffer the entire battle atop the ridge of Mont St. Jean, the wounded Inniskillings were eventually seen by the regimental surgeons. The lightly wounded would be bandaged and returned to the regiment. Private Michael Kain, for instance, was wounded but missed no duty. The more seriously wounded would be admitted to the regimental hospital; Private Thomas O'Hara missed a muster after Waterloo, but was excused to the regimental hospital. O'Hara's wound must not have been too severe, as he spent only fifteen days in the hospital, and by the next month's roster he was back in the ranks. The most severely wounded would be sent to a general hospital. Private Edward Burke spent two months in the general hospital, and was then returned to England. The detailed rosters for the period from the battle until September 1815 show that the wounded men of the $1 / 27^{\text {th }}$ spent more than twelve thousand seven hundred days in the regimental and general hospitals. ${ }^{353}$

The administrative system utilized by the British army of the early nineteenth century was effective, and also reinforced the cohesion and motivation of the men in the ranks of the army's regiments. Unlike most of the rest of Europe, Great Britain did not turn to conscription during the Napoleonic era. While the British army never grew to the size of the great continental powers, the recruiting system used to man Britain's regiments was effective

\footnotetext{
${ }^{352}$ Regimental Newspaper, The Sprig of Shillelagh, June 1, 1891, Inniskilling Regimental Museum, Enniskillen.
} 
in gathering enough men of sufficient quality to garner victory. How the families of Britain's soldiers were treated is one of the failings of the administrative system; while the eighteenth and nineteenth centuries were hard years for poor families, the Britain failed to support the families of the men who risked all for the Empire. While the equipment, food, and drink supplied to the soldiers were never luxurious, they were usually supplied on time, in sufficient quantity, to keep men in the field. By modern standards the medical services were primitive, but there are no complaints regarding medical care in any many memoirs reviewed for this thesis. Doubtless there were many poor men who had never seen a doctor before they joined the army.

\section{Organizational System}

The basic building block of the British infantry was the private with his musket on his shoulder. Two soldiers, one behind the other, constituted a file. From six to fifteen files would be combined to make a section of twelve to thirty men. Two sections went into each sub-division, and two sub-divisions went into each company. The actual strength of an infantry company depended on the number of men in the battalion; the officers would make every effort to make each of the ten companies equal in strength, as uniform company frontages were vital to maneuvering the battalion. The strengths of the British infantry battalions at Waterloo varied widely: the $2 / 3^{\text {rd }}$ Foot Guards fielded 1,139 enlisted men, while the $1 / 42^{\text {nd }}$ Highlanders, the Black Watch, could manage only $347 .{ }^{354}$

A British infantry battalion consisted of ten companies; eight center or "line" companies numbered 1-8, one light company, and one grenadier company. The grenadiers were to be the tallest, strongest, and bravest men available, and they were always to be posted

\footnotetext{
${ }^{353}$ United Kingdom War Office, $1 / 27^{\text {th }}$ Regimental rosters, 1815-1816.

${ }^{354}$ Scott Bowden, Armies at Waterloo, 232, 251.
} 
on the right of the battalion. The light company was to be composed of small, agile, intelligent men who would skirmish in loose order in the front of the battalion.

Most British infantry regiments had two battalions, but there were many exceptions. For example, in the Napoleonic era the $1^{\text {st }}$ Foot, the Royal Scots, had four battalions, while the $2^{\text {nd }}$ Foot, the Queen's Own, had only one. It was rare for a regiment's battalions to serve together; usually the battalions were widely scattered across Britain's numerous theaters of war. In 1815 the first battalion of the Royal Scots was in Canada, the second was in India, the third was in Belgium, and the fourth was in America. ${ }^{355}$

Three to five battalions would be combined to make a brigade. Typically two to three brigades constituted a division, and then three to four divisions were combined to make a corps. Several corps made an army, but each army was different, and very often an army's organization would change as a campaign wore on.

In 1815 the first battalion of the Inniskillings was in Canada, Bermuda, and of course, Belgium and France. The second battalion was in England, and the third battalion was in Canada, and later in France. The 1/27th had only seven of their ten companies at Waterloo, and their battalion staff was missing as well, so the organization of that battalion was unique to the British army that day. With more than seven hundred enlisted men in the ranks, each company would have consisted of about a hundred men.

All the primary sources agree that the $1 / 27$ th was in square or column of companies at quarter distance, so the two diagrams below will illustrate explain just how the men were deployed. The light company would have been deployed along the sunken road to the battalion's front, and since the grenadier company was still at sea, the front of the formation would have been assumed by the first center company. 
Table 28 .

Column of Companies

At Quarter Distance

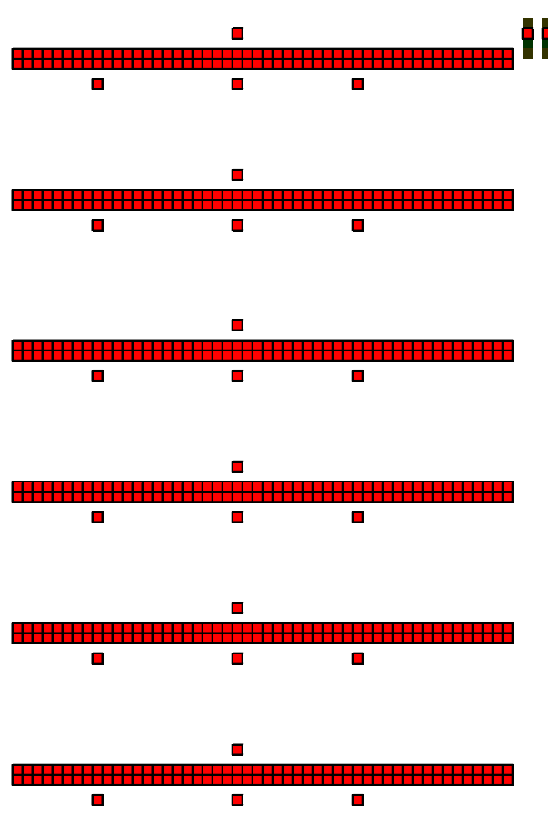

\section{Square}

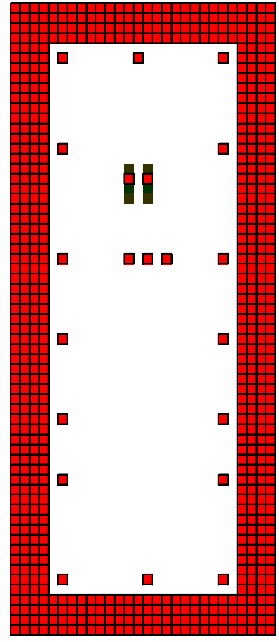

Each square in the diagrams above represents one man; the density of the formations is obvious. The Inniskillings' column would have been about one hundred feet wide, and about three hundred feet deep; there would have been more than seven hundred men in an area about the size of a football field. The square formation was even more dense; those seven hundred men were in a formation about fifty feet wide, and two hundred feet deep.

The effectiveness of the organizational system utilized by Britain for its infantry can be judged by the victory that they eventually won. While there are many other factors that contributed more to that victory than the organizational system, it is important to understand how the men were organized if a true understanding of their mindsets is to be gained. Where a soldier stood, and the proximity of his comrades and officers, are useful in trying to understand just what it was like to see combat in 1815 .

\footnotetext{
${ }^{355}$ Park \&Nafziger, British Military, 92.
} 


\section{Command System}

The study of the command system that functioned in the British army of 1815 is based on the promotion of both officers and enlisted men, and the communication that tied together the diverse elements of the army.

As with any corporate body, the possibility of promotion is a key factor in understanding the structure and behaviors of the group. Both the qualifications for promotion and the methodology by which promotions were obtained should thus be of prime consideration, for both the enlisted men and officers of the British army of the day. Enlisted men could hope for promotion to one of the non-commissioned officer ranks, and very rarely, an officer's commission. An officer could start as a lowly ensign and might eventually reach the exalted rank of general.

The number of NCO posts in a company varied according to its strength. In a company of sixty men, regulations of the day called for three sergeants and three corporals for each of the ten companies. If company size was one hundred men, there were to be four sergeants and corporals. Usually one of the sergeants of each company was designated Color Sergeant, involving more pay, prestige, and responsibility. Further, regulations called for several more NCOs in the battalion staff: one quartermaster sergeant, one sergeant major, one armourer sergeant, and one school master sergeant. ${ }^{356}$

Interestingly, there were few formal regulations regarding promotion within the ranks; the officers of the battalion had considerable discretion in promoting the rank and file. Further, perhaps because of the lack of written regulations, there is a discernable lack of indepth research into the topic. ${ }^{357}$ However, an unpublished paper by John Duncan Ellis is of

\footnotetext{
${ }^{356}$ Park and Nafziger, Military, 28

${ }^{357}$ Two examples of otherwise excellent secondary sources: Haythornthwaite, Armies, gives it only a page (54), while the masterful Holmes, Redcoat, seems to skirt it entirely.
} 
considerable interest in its study of promotion in the ranks of the $1 / 28^{\text {th }}$, or North Gloucestershire Regiment. ${ }^{358}$

Ellis bases his analysis upon the influence of literacy, previous civilian employment, nationality, length of service, and previous military service in the $1 / 28^{\text {th }}$, with comparisons to three other Waterloo regiments (the $1 / 27^{\text {th }}$ was not included in the study). Literacy seems a crucial qualification, as $63 \%$ of corporals and $96 \%$ of sergeants were literate in the $1 / 28^{\text {th }}$. Previous civilian employment was also a major component in eligibility for promotion, as those who once held skilled jobs comprised a marked majority of NCOs.

Of particular interest to this study of the Inniskillings was Ellis' analysis of national bias in the promotion of rank and file. In two of the three regiments that Ellis studied, Irish NCOs accurately represented the number of Irishmen in the battalion as a whole. The $1 / 28^{\text {th }}$, despite its designation as the North Gloucestershire Regiment, had drawn $40 \%$ of its rank and file from Ireland, and 38\% of its NCOs were Irishmen. Ellis notes, however, that while he lacks solid evidence, there are hints that Protestant Irishmen had an advantage over their Catholic countrymen.

Lastly, Ellis finds that length of service was not of great importance in the selection of NCOs, as many junior men filled those positions. Previous military experience was also of minor import; men drawn from militia units were no more likely to become NCOs than those men who were drawn directly from the general population.

Doubtless all of the factors listed above were considered by a regiment's officers in the selection of NCOs, but there is evidence that selection was not always based on merit. An officer of the $4^{\text {th }}$ Regiment (who were brigaded with the Inniskillings at Waterloo) wrote: "If commanding officers paid more attention in the choice of non-commissioned officers, we

\footnotetext{
${ }^{358}$ John Duncan Ellis, "Recruitment and Promotion in the Napoleonic British Army: A Study of the $28^{\text {th }}$ (North Gloucestershire) Regiment of Foot, an English Regiment at Waterloo" (BA (Honors) dissertation,
} 
would see the interior discipline of our infantry superior to its actual state; and, instead of having the husbands of our officers' washer-women corporals and serjeants, we would have men capable of regulating the interior oeconomy of their squads- they should always be selected from the veterans". 359

The British officer corps consisted nearly entirely of "gentlemen", though there were rare instances of enlisted men receiving commissions. On those occasions when a deserving ranker was granted a commission, he often faced considerable resistance from his fellow officers and sometimes even from the enlisted men. Wellington was typical of many tradition-bound elite officers when he argued that rankers

do not make good officers; it does not answer. They are brought into a society to the manners of which they are not accustomed; they cannot bear at all being heated in wine or liquor...they are quarrelsome, they are addicted to quarrel a little in their cups. And they are not persons that can be borne in the society of the officers of the Army; they are different men altogether. ${ }^{360}$

Wellington's opinions notwithstanding, there were instances of rankers succeeding as commissioned officers. But the men who did succeed also had to prove themselves to enlisted men such as Rifleman Benjamin Harris of the $1 / 95^{\text {th }}$ who felt that gentlemen were naturally kind, whereas former enlisted men were harsh and overbearing. Men like Harris felt more comfortable being commanded by a gentleman, a man "who has authority in his face" 361

The promotion of officers in the British army in the early $19^{\text {th }}$ century is a spectacularly complicated issue. Social status, influence, nationality, financial resources, ability and random chance are all factors to be considered in such a study.

Cheltenham and Gloucester College, 1999), 15-24.

${ }^{359}$ Captain Aylmer Haly, "A Letter to Colonel Brownwigg" in The British Military Library or Journal, vol II., (London: British Military Library, 1800), 267.

${ }^{360}$ Wellington, quoted in Richard Holmes, Redcoat, 170-171.

${ }^{361}$ Rifleman Benjamin Harris, Recollections of Rifleman Harris (Hamden, CT.: Archon, 1970), 67. 
An example of a near-perfect combination of all the factors necessary for rapid advancement is the Inniskillings' divisional commander, General George Lowery Cole. Lowery Cole was born in Enniskillen in 1772, and as second son of the Earl of Enniskillen he carried all the necessary credentials. Lowery Cole had great social status as the son of a peer, and his family was exceptionally influential in both Irish and English political circles. ${ }^{362} \mathrm{He}$ was born in Ireland, but like Wellington his status as an elite member of the Protestant aristocracy overcame any negative connotation of having an Irish birth place. Further, the Coles possessed the enormous financial resources necessary for an ambitious officer to purchase high rank. Cole is deemed to have had the ability and physical courage that was not a mandatory prerequisite to advancement, but that was an added impetus to an army career. Lastly, Cole lived in a time of war when chance offered ample opportunity for advancement. $^{363}$

All these factors combined to give Lowery Cole high rank at a young age. After enlisting at age 15, Lowery Cole was a Brigadier General by age 34 .

$\begin{array}{lll}\text { Cornet } & 12^{\text {th }} \text { Lt. Dragoons } & 1787 \\ \text { Lieutenant } & 5^{\text {th }} \text { Dragoon Guards } & 1791 \\ \text { Captain } & 70^{\text {th }} \text { Foot } & 1792 \\ \text { Major } & 102^{\text {nd }} \text { Foot } & 1794 \\ \text { Lieutenant Colonel } & \text { Vilette's Regt. } & 1799 \\ \text { Lieutenant Colonel } & 3^{\text {rd }} \text { Dragoon Guards } & 1803 \\ \text { Brigadier General } & & 1806 \\ \text { Major General } & & 1808 \\ \text { General } & & 1811 \\ \text { General } & & 1830^{364}\end{array}$

Lowery Cole was appointed to command the $6^{\text {th }}$ Infantry Division during the Campaign of 1815, but he was not present at Waterloo as he had taken leave to return to England to be married. Upon hearing of Napoleon's advance into Belgium Cole quickly

\footnotetext{
${ }^{362}$ Allan Blackstock, An Ascendancy Army, 77-78.

${ }^{363}$ Lowery Cole, Memoirs, 64.

${ }^{364}$ United Kingdom War Office, Army List, 1836.
} 
returned to his command and was present at the Allies' eventual capture of Paris. Cole's reputation and extensive military service absolved him of any onus of dishonor at having missed Waterloo, and the pragmatic Cole wrote "however I regret - for I cannot help a sort of regret at not having witnessed the glorious result of Waterloo - I feel at the same time that it is by no means improbable that I might not have survived that day!"365

There were five avenues for promotion of officers- rank by recruiting, promotion by brevet, selection by merit, losses on campaign, and purchase. ${ }^{366}$ Rank by recruiting was given to officers who raised a required number of men for army service. Promotion by brevet was a rare reward for bravery in action; Captain John Hare who commanded the Inniskillings at Waterloo was a captain in the regiment, but held a brevet rank of major in the army. Selection by merit was also a rare method of promotion, by which the commander in chief in a theater could promote deserving volunteers or enlisted men. The effects of influence could be applied in any one of these three paths to promotion; an officer with status and powerful friends could utilize his connections to manipulate the system much more than a deserving officer who lacked influence.

Promotion as a result of the death of one's superiors was particularly prevalent during wartime, though death by accident also meant opportunities for junior officers. For example, as the Inniskillings returned to England after service in America, there were rumors that the ship containing the battalion headquarters had been lost at sea. Lieutenant Charles Crowe of the third battalion wrote "that it was really disgusting to hear the levity of remarks, on the chance of such an event proving true, and the great promotion resulting, made with unblushing front by some individuals."

\footnotetext{
${ }^{365}$ Lowery Cole, Memoirs of Sir Lowery Cole (London: Macmillan and Company, Limited, 1934), 145.

${ }^{366}$ Gunther Rothenberg, Art of Warfare, 175-176, and Phillip Haythornthwaite, Armies, 26-33.

${ }^{367}$ Lt. Charles Crowe quoted in Martin Cassidy, Marching, 136.
} 
The main route to the rapid promotion experienced by men such as Lowery Cole was the purchase system that had been a part of the British army since the inception of a standing army in $1665 .^{368}$ One of the original purposes of the sale of commissions was to fund the monarchy, but by the $18^{\text {th }}$ century Kings George I and George II were less interested in the income than the promotion of more capable officers. A series of reforms eliminated the worst abuses of the system, such as mere children possessing a colonelcy and officers openly selling their commissions for outrageous profits. ${ }^{369}$

All reforms aside, during the Revolutionary and Napoleonic Wars purchase accounted for three-quarters of all commissions in the British army, and "was the single most important route for the entry and promotion of officers". ${ }^{370}$ This reliance upon purchase fulfilled a secondary purpose of the purchase system, in that officers with substantial financial investment in the army dominated its highest posts. ${ }^{371}$ Men of means who had considerable investment in the army were more likely to possess a particular devotion to the status quo, and as such the King was anxious to have such loyal men commanding his armies during a period of revolutionary fervor. ${ }^{372}$

The strategy of using purchase to engage those who were most capable of investment in the army extended into the prices charged for commissions. Equivalent ranks in the Guard infantry and the Line infantry regiments varied dramatically: an ensigncy in the Foot Guards would cost a new officer $£ 900$, while in the Line an ensigncy cost only $£ 400 .^{373}$ The prestige and social influence which was commensurate with a commission in the Foot Guards thus went to only the wealthiest men, not necessarily to Britain's best soldiers.

\footnotetext{
${ }^{368}$ Park \& Nafziger, British Military, 11.

${ }^{369}$ John Brewer, The Sinews of Power (New York: Alfred A. Knopf, 1989), 57.

${ }^{370}$ Gunther Rothenberg, Art of Warfare, 176.

${ }^{371}$ J.A. Houlding, Fit for Service, 102.

${ }^{372}$ John Brewer, The Sinews of Power, 44-45.

${ }^{373}$ Charles James, Regimental Companion, vol. I, 37.
} 
The inequities of the purchase system were hardest on capable, experienced officers who saw extensive service but who were often passed over for promotion. Even enlisted men commented on the injustice; Private Morris of the $73^{\text {rd }}$ commented that "as soon as vacancies occur in a regiment they are filled up by mere boys just from school". ${ }^{374}$

Another problem inherent in the purchase system was that some officers stayed with their regiments for only two or three years before purchasing their next step in another regiment. An officer who "exchanged into four or five different regiments (which frequently happens)" ${ }^{375}$ would be hard-pressed to learn the responsibilities inherent with his post, but just as importantly he would not establish any type of meaningful relationships with the officers and men of the regiment.

Lastly, officers with little formal training or experience sometimes felt that purchasing their commission entitled them to use their own discretion regarding their behavior in the army. Wellington complained that "nobody in the British Army ever reads a regulation or an order as if it were to be a guide for his conduct ... every gentleman proceeds according to his fancy" ${ }^{376}$ While Wellington overstated the case, his frustration in commanding an army that contained so many independent-minded amateurs is very evident.

There remains substantial difference in the literature regarding the effectiveness of the purchase system. Experts such as Richard Holmes and Gunther Rothenberg highlight the problems of purchase, but recent work by J.A. Houlding argues that the system was "secure, economical, and convenient". The final word comes from Wellington, as he complained that excesses by the troops could only be attributed

to the utter incapacity of some officers at the head of regiments to perform the duties of their situation, and the apathy and unwillingness of others; to the

\footnotetext{
${ }^{374}$ Private Thomas Morris, Recollections, 153.

${ }^{375}$ Charles James, Regimental Companion, vol. II, 437.

${ }^{376}$ Wellington, quoted in Michael Howard, "Wellington and the British Army", in Studies in War and Peace (New York: Viking, 1970), 52-55.
} 
promotion of officers in regiments by regular rotation, thus holding forth no reward to merit or exertion, and leaving all in a state of equal indifference and apathy whether their superiors have, or not, reason to be displeased with them; and to the difficulty, if not impossibility, of punishing any officer for neglect of duty, when he is to be tried by others, each and all of whom have been guilty of the same, if not greater neglects. In general such neglects are punished by sentencing the Commander-in-Chief to reprimand the officer, which is just so much waste paper. ${ }^{377}$

There are no specific records regarding the promotion of the men or officers in the $1 / 27$ th. Other records can be utilized to extrapolate some theories, but the data for the enlisted men is particularly thin. There are no records at all regarding literacy, and the records regarding civilian employment, nationality, length of service, and military experience, while incomplete, indicate that the trends seen in the enlisted population as a whole were also seen in the ranks of the NCOs.

The information for the promotions amongst the officers of the $1 / 27^{\text {th }}$ can be gleaned from the Army List. ${ }^{378}$ For example, Andrew Gardner joined the 1/27th in 1811 as an Ensign. In 1813 he was promoted to Lieutenant in the 1/27th; he did not purchase his step, so his promotion was doubtless due to a casualty in the battalion.

One of the success stories of the battalion was Captain John Hare, who commanded the $1 / 27^{\text {th }}$ at Waterloo. Hare enlisted at the age of 16 into the Tarbet Fencibles, from which he volunteered with 300 men into the $69^{\text {th }}$ Foot. He transferred the same year into the $27^{\text {th }}$, still as an ensign. He rose to Lieutenant without purchase in 1800 , then to Captain in 1805 , again without purchase. Both of those steps were probably due to casualties in the officers above him, but in 1813 he was given the rank of Brevet-Major as a reward for bravery in action. He was made Brevet-Lt. Colonel due to his bravery at Waterloo. He purchased his Majority in 1813, and then reached Lt. Colonel by purchase in 1825. It seems likely that Hare lacked the financial resources need for quick promotion, and early in his career

\footnotetext{
${ }^{377}$ Wellington to Colonel Henry Torrens, March 1814, in Anthony Brett-James, Wellington at War, 290.
} 
managed to reach higher ranks only through raising volunteers and by casualties in the ranks above him. He must have come into money later in his life, as only through purchase was he able to realize his brevet ranks.

A final example is Lieutenant Thomas Craddock, who bounced between the $27^{\text {th }}$, $93^{\text {rd }}, 81^{\text {st }}, 64^{\text {th }}, 35^{\text {th }}$, and $34^{\text {th }}$ Regiments of Foot during his 23 year career. As the seventh son of a Leicester family, it is doubtful that family money played much of a role in his army promotions.

As a whole, the officers of the Inniskillings were slow to rise in rank. Many obviously depended on battle casualties to move ahead, as the number of steps taken by purchase were much fewer in number than seen in most other regiments. ${ }^{379}$ Even with the opportunities offered by years of war there were many officers who ended long careers at the rank of just Lieutenant or Captain. As can be seen in the chart below, two of the Waterloo officers achieved the rank of General, but their rise was hardly meteoric. George M'Donnell was an ensign in 1805, and a Lieutenant in 1806; it would require fifty years of service to reach the rank of general. William Smith required forty-nine years to reach general, while the wealthy and powerful Lowery Cole required only nineteen years.

\footnotetext{
${ }^{378}$ Great Britain, Army, Army List, 1836.

${ }^{379}$ ibid., et al
} 
Table 27

\section{Career Paths of the Waterloo Officers, 1/27th Foot}

Shows date of rank held at Waterloo, and date of rank at end of army career

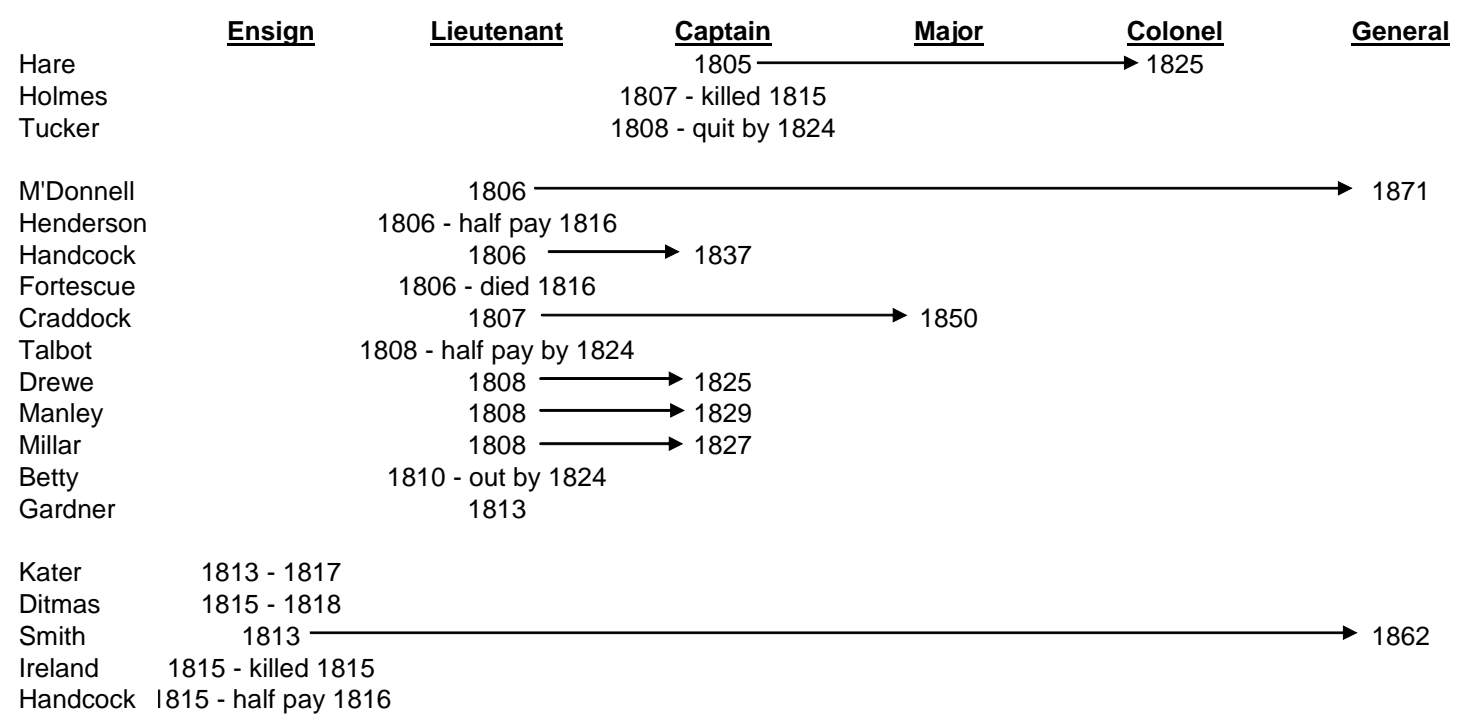

After Waterloo the brave Captain John Hare would serve twenty years before reaching his colonelcy, while Lieutenant John Craddock served forty-three more years to reach major. The rest of the officers faded away; several toiled for years to attain their captaincy, but rose no further. Others resigned or went on half-pay and faded into civilian life. Lieutenant Andrew Gardner was still living on his half pay of 2s. 4d. a day in $1874 .{ }^{380}$

In the years before radios all armies exchanged information by written messages or verbal communication. Those messages could be conveyed in person by the commander, or carried by aides-de-camp or other mounted messengers. For example, Wellington's orders for the Inniskillings and the rest of the $6^{\text {th }}$ Division to march were carried by a Dragoon Orderly. ${ }^{381}$

Communications between the different levels of the command structure were crucial to the smooth operation of an army. While most European armies communicated primarily 
along the lines of command, the British army of 1815 was unusual in that Wellington often by-passed the chain of command and communicated directly with divisional, brigade, and even battalion commanders. A written communication from Wellington to the commander of the garrison of Hougomont survives; it is written in pencil, on goats' skin that could be wiped clean and used again. ${ }^{382}$

Dozens of Waterloo veterans commented on instances of Wellington giving verbal orders throughout the battle as he constantly rode from crisis to crisis along the line. For example, Ensign William Leeke wrote that, "the Duke rode across our front from the left of the line quite alone, and spoke to Sir John Colborne, as they were both sitting on their horses observing the enemy". ${ }^{383}$ Late in the day as the Anglo-Allied victory was apparent, Captain John Kincaid of the $95^{\text {th Rifles }}$ recalled that "Wellington galloped up to us at the instant, and our men began to cheer him; but he called out, 'No cheering, my lads, but forward, and complete your victory", 384

While Wellington's commands comprised the most memorable communications in the Anglo-Allied army at Waterloo, the communications between the lesser officers of the army were every bit as important. While few details remain regarding the communications of the officers commanding the Inniskillings, General Sir John Lambert's letters reveal that he spent most of the afternoon with the square of the $27^{\text {th }}$, where the fighting was most fierce. Records show that officers of the $95^{\text {th }}$ spoke with Lambert about a possible attack on the French line, "but the Duke's orders on that head were so very particular that the gallant general (Lambert) had no choice". ${ }^{385}$ The officers of the $27^{\text {th }}$ were also communicating with

\footnotetext{
${ }^{380}$ Charles Dalton, Waterloo Roll Call, 132-134.

${ }^{381}$ Lt. Drewe, Memoirs, 112.

${ }^{382}$ Mark Adkin, Waterloo Companion, 94.

${ }^{383}$ Ensign William Leeke, History, 211.

${ }^{384}$ Captain John Kincaid, Adventures, 301.

385 ibid., 300.
} 
the battalions near them; at one point Captain John Hare of the Inniskillings spoke to the officer commanding the $1 / 40^{\text {th }}$. Lieutenant John Mill recalled that "the officer commanding the Twenty-Seventh, when there was temporary cessation from artillery, rode up to our major, and announced the fact of having barely an officer left to command each company". ${ }^{386}$ There was substantive communication between the every level of the officer corps of the Anglo-allied army.

There was communication between battalions by enlisted men as well. When the $2^{\text {nd }}$ Dragoons, the Scots Greys, passed the $92^{\text {nd }}$ Foot, the Gordon Highlanders, during the great British cavalry charge the Scottish horsemen cried "Hurrah, Ninety-Second! Scotland for Ever!". 387 The communication between units, even alleged allies, was not always so positive. When a regiment of Belgian cavalry behaved badly a number of men of the $14^{\text {th }}$ Foot "unanimously took up their places and fired a volley into them". ${ }^{388}$

Further, there was communication within the battalions of the army. In fact, the very size of modern European army units was mandated by the power of the human voice. The innovative Prince Maurice of Nassau first devised battalion-sized units around 1600, as convenient units for drill, since "a single voice could control the movements of all of the men". ${ }^{389}$ Effective communication at the battalion level was crucial for tactical success; Sergeant William Lawrence of the $1 / 40^{\text {th }}$ Foot wrote that when their square was attacked by heavy French cavalry, "the word having been given not to fire at the men, who wore armour, but at the horses, which was obeyed to the very letter, as soon as they arrived at close quarters we opened a deadly fire, and very few of them wholly escaped". 390

\footnotetext{
${ }^{386}$ Lt. John Mill, $1 / 40^{\text {th }}$, quoted in Regimental Historical Records Committee, The Royal Inniskilling Fusiliers, 263.

${ }^{387}$ Corporal John Dickson, quoted in Anthony Brett-James, Hundred Days, 117.

${ }^{388}$ Anonymous memoir, $14^{\text {th }}$ Foot, quoted in Keegan, Face of Battle, 157.

${ }^{389}$ William H. McNeil, Pursuit of Power, 130.

${ }^{390}$ Sgt. William Lawrence, Autobiography, 254.
} 
Lastly, there were instances of non-verbal communication at Waterloo that deserve mention. Private Scheltens of the $7^{\text {th }}$ Belgian Line noticed two wounded French officers; "they gave me the Masonic sign, so I happened to take them to the rear where they ... reached Brussels safe and sound. ${ }^{, 391}$ Later, when French cavalrymen attempted to intimidate the $1 / 40^{\text {th }}$ "with fierce gesticulation and angry scowls, in which a display of incisors became apparent" the British officers ordered their men to respond in kind: "Now men, make faces!"392

The command system in the British army of 1815 used promotion and communication to motivate, control, and hold together men in battle. Promotion was used to find the best men to lead the troops, but was also a motivation tool to reward men for good service. Communication in modern armies is usually thought of in terms of high-tech radios and computer traffic. But Waterloo showed that communication even in its most simple terms is critical to cohesion in battle, and can be made at the most personal level.

\footnotetext{
${ }^{391}$ Private Scheltens, quoted in Anthony Brett-James, Hundred Days, 114.

${ }^{392}$ Sgt. William Lawrence, Autobiography, 255.
} 


\section{CONCLUSIONS}

The First Battalion of the Inniskilling Regiment suffered terrible losses to French artillery and musketry fire at the Battle of Waterloo. The maelstrom of French fire was overwhelming; the "Dutch-Belgians, east of La Haye Sainte, were demoralized by it and decamped; the Inniskillings, who stood their ground, drew their wounded into the square, threw their dead out and closed their ranks, were destroyed.."393 Of the seven hundred thirty Inniskillings at the battle, one hundred three were killed, and three hundred sixty were wounded. That loss of $63 \%$ was the most severe loss percentage suffered by any Allied unit at Waterloo.

The numbers are compelling, but fail to convey the true human nature of the ordeal. These were men; individuals beyond the cold calculus of casualty counts. Digging into the rosters it can be seen that there were two men named John Collins in the first company, both of whom were wounded. The first survived his injuries, but the second lingered until August $2^{\text {nd }}$ before dying of his wounds. Privates Neil and Thomas McHugh shared the same unusual surname; they may have been brothers. Both were wounded, though two other possible siblings, Arthur and George McCormick, miraculously came through unhurt. Two of the other wounded men, Terence McCabe

\footnotetext{
${ }^{393}$ John Keegan, The Face of Battle, 142.
} 
and Arthur McMahon, were the last of the Inniskillings to die, within a day of each other: McCabe on September $24^{\text {th }}$, McMahon on the $25^{\text {th }} \cdot 394$

There were numerous elements of motivation and cohesion that allowed the Inniskillings to bear such losses and yet remain in their ranks. Interest was one of those factors; while no Inniskilling was likely to be thinking of his pay when in battle, the prospect of plunder was a certainly a motivation. Another part of a soldier's interest was the avoidance of the coercive control that was an inherent part of the British army. Any Inniskilling who thought of fleeing the battle would have had to consider the pikes of the sergeants, and the swords of the officers.

The morale of the $1 / 27^{\text {th }}$ was also a key contributor to the battalion's ability to face the stresses of battle. The battalion was composed primarily of seasoned, professional soldiers, bred of an Irish heritage of military service. The Inniskillings were accustomed to battle, and to the privations of army life. They possessed an esprit de corps born of long service and tradition, exemplified by the defense of the battalion colors.

Group cohesion was perhaps the greatest contributor to the Inniskillings' stand beside the Charleroi road. Both physical and emotional elements of cohesion held the battalion together. Physical cohesion was an integral part of the square formation adopted by the Inniskillings for most of the battle. No man felt isolated; each man was close to his comrades, NCOs, and officers. The Inniskillings wore the uniform of the British line infantry, but with the buff facings and regimental badges that gave them a unique group identity.

\footnotetext{
${ }^{394}$ United Kingdom War Office, $1 / 27^{\text {th }}$ Regimental rosters, 1815-1816.
} 
Lastly, the bravery and sense of honor that was typical of the men and officers of the British infantry at Waterloo was very evident in the Inniskilling Regiment. The fact that the regiment did not break was the best evidence of bravery and honor. The men and officers suffered the wounds necessary to prove their dedication. Terms like bravery and honor may sound trite or hollow to modern American civilians, but to the soldiers of the Inniskillings of 1815 they were considered mandatory traits of men.

The elements of cohesion that are listed above were evident to varying degrees in every British unit, indeed every unit of every nationality, at Waterloo. There were, however, elements of cohesion that were unique to the Inniskillings. Unlike almost every other unit in the British army of the day, the $27^{\text {th }}$ Foot consisted almost exclusively of men from one area. Not only were those men from one area, that area was a unique nation. The men were Irish, and if they suffered from their own internal divisions, the factors that unified them were more powerful. The men may have been divergent in religion and language, but a common heritage of illiteracy and poverty bound them together. Most of the men of the $1 / 27^{\text {th }}$ were unskilled men, having only rudimentary farming or weaving skills. They were from the lowest echelons of Irish society, and their concerns were more with survival than with politics. Being Irish, particularly an Irish Catholic, in a British army could provoke considerable disdain, but any Irishman, even a Catholic who spoke only Irish, would have had a home with the $27^{\text {th }}$.

The Inniskillings possessed all the requisite cohesive factors found elsewhere in the British army, but they also possessed a trait that was nearly unique to them. They were Irish, and whether they realized it or not, it helped to hold them together in the square atop the ridge of Mont St. Jean. 
Troubling questions remain. The battalion served their British masters, but so what? Considering the interest that this paper places on the role of the individual, would not the men of the Inniskillings have been better off to have fled the line at Waterloo? Did they die in vain?

It has to be conceded that the men of the $1 / 27^{\text {th }}$ would, as individuals, have been better served if they had fled the horrendous situation in which they were placed at Waterloo. Many other men, of all the armies and nationalities at the battle, fled the field. That was how battle worked; to inflict losses on units to force the surviving members of the unit to flee. But no British units routed from their positions at Waterloo. Some had temporary disorder in their ranks, and of course some individuals fled the battle, but remarkably no British unit broke. In the years after the battle many British historians heralded the bravery of their army compared to both their French enemies and their Dutch, Belgian, and German allies. Had the Inniskillings broken, the Irish would have been propelled even further into the role of the disdained "others." It is doubtful that the Inniskillings knew it, but through their service and suffering they earned their people an inkling of respect. The individual suffered, but the group reputation was enhanced.

The role of the individual is a vital part of military history, as war is, at its most basic level, a human activity. Understanding the human experience in battle gives military history its fullest significance and resonance. Historians can take a lesson from Captain John Kincaid of the $1 / 95^{\text {th }}$, who wrote that soldiers

are apt to have a feeling ... that they are but insignificant characters - only a humble individual out of many thousands, and that his conduct, be it good or bad, can have little influence over the fate of the day. This is a monstrous mistake ... for in battle, as elsewhere, no man is insignificant unless he chooses to make himself so ... men in battle may be classed under the disproportionate heads - a very small class who consider 
themselves insignificant - a very large class who content themselves with doing their duty, without going beyond it - and a tolerably large class who do their best, many of which are great without knowing it. ${ }^{395}$

If Captain Kincaid gave voice to the importance of role of the individual soldier in war, the Duke of Wellington played the opposite role. Wellington thought that input into the histories of great battles should be restricted to the province of the commanding

General. Wellington wrote that when the novelist Sir Walter Scott

came to Paris to enquire into details about the Battle of Waterloo, instead of applying to me, as the principal of the Staff Officers with whom he was associating daily at night and in my house, he seeks out a Highland Serjeant Corporal, or Serjeant, who crammed him with lies, not only about the Battle, but the details of his Military Life and Adventures.

I recollect such a fanciful man as Sir Walter Scott proposing to me to have a history written on the Battle of Talavera, by calling upon every individual who desired to write down his own account and refer these accounts to one Individual to make out a narration! I answered that it would be as easy to write the account of a ball as a Battle! ${ }^{396}$

Military history followed Wellington's path; the role of Generals was heralded,

the contributions of lower ranks was forgotten. Even in the case of Captain William

Siborne and his history of Waterloo, the battle accounts of individuals that were collected were restricted to British officers. Siborne was representative of his time, but the modern scholar may rightly mourn what Siborne might have accomplished.

Ignored by history, the great majority of the Inniskillings who fought at Waterloo quickly faded into anonymity. The process of forgetting those men was not simply historical; it was also bureaucratic. Lieutenant William Faithful Fortescue was badly wounded at Waterloo, being shot through the arm and the chest. ${ }^{397}$ He miraculously

\footnotetext{
${ }^{395}$ Captain John Kincaid, Adventures, 210.

${ }^{396}$ Wellington, in Anthony Brett-James, Wellington at War, 162-163.

397 The story of the Fortescues is contained in a series of letters and pension forms found in United Kingdom War Office, Pension submission, Lt. William Faithful Fortescue.
} 
recovered, but the chest wound left him with a degenerative lung condition. Fortescue had a wife and five children to support, and he could not afford retirement on a lieutenant's half pay of $2 \mathrm{~s}$. $4 \mathrm{~d}$. a day. He returned to active duty as long as was possible, but he was eventually forced to return to his home in Clonakilty in the County Cork. Fortescue was given the rare honor of assignment to the $3^{\text {rd }}$ Royal Veteran's Battalion, where he could retire on what was essentially full pay.

William Faithful Fortescue died on June $21^{\text {st }}, 1821$. As a Waterloo veteran, an officer of the $3^{\text {rd }}$ Royal Veteran's battalion, and son of an officer who had served at the capture of Quebec, one would think that his family would have little trouble in drawing his pension. But the payment of the pension was strangely delayed. Since Fortescue's $3^{\text {rd }}$ Royal Veteran Battalion was on the Irish Establishment, the pension request went through Dublin Castle rather than through the Horse Guards in London. Dublin Castle had to be convinced that Fortescue did indeed die of his Waterloo wounds and not of natural causes; letters from his two attending physicians were obtained, and forwarded. The bureaucrats at Dublin Castle then required birth certificates of the Fortescue children; the frantic widow had only three such certificates, and had to explain the two missing records.

The Castle then required the Marriage Certificate, and the true nature of the delay finally surfaced: William Faithful Fortescue, a son of the Protestant Ascendancy, had had the temerity to marry a Catholic woman. Fortescue had married Honoria O'Brian in 1798 , the year of the bloody Rebellion that had shaken Ireland and further polarized the Catholic-Protestant divide. A letter by the wedding's two witnesses, "Catherine 
O'Regan, formerly McCarthy, and Ann Casey, formerly O'Brian" may have been from daughters of two great Irish families, but their input may have hurt more than it helped.

An increasingly desperate Honoria Fortescue turned to Lieutenant Fortescue's former comrades, and testimonials from many of the Inniskilling officers, including Captain, now Major, John Hare, were sent to the Duke of York to attest to Fortescue's sacrifice and his family's desperate need. A letter from the Horse Guards, signed by the Secretary of War, Lord Palmerston, directed Dublin Castle to review the case. An acidly polite reply from the secretary to the Lord Lieutenant of Ireland stated that

I am, in answer, directed by His Excellency to state, for the information of the Secretary of War, that the certificate in question (herewith returned) appears, on inquiry, to be authentic, but that the late Lieutenant Fortescue was a Protestant, and Mrs. Fortescue a Roman Catholic.

It may however be proper to observe, that one of the parties having been a Protestant, the other a Protestant or Roman Catholic, the marriage, as now certified, is not by law valid. A marriage of Persons so circumstanced by a Roman Catholic Priest was once a Felony, and is still highly penal, unless the parties were previously married by a Protestant clergyman. ${ }^{398}$

Under pressure from London, eight months after Lieutenant Fortescue's death Dublin Castle relented and authorized the pension. But by then it was too late; Honoria Fortescue had also died, without knowing if her children would be cared for. It is unknown how the financial pressures affected her health. The Fortescues' oldest daughter, Honora, age twenty-one, carried on her mother's work and inquired about the pension on behalf of her younger siblings. The records close with yet another obfuscating official letter, confusing Honora with her late mother Honoria.

\footnotetext{
${ }^{398}$ Henry Goulburn to Lord Palmerston, February 1, 1822, in Pension submission, Lt. William Faithful Fortescue.
} 
The Inniskillings had largely overcome much of the divisiveness of eighteenth century Irish society, but that society had begun to pull apart the cohesiveness forged in long service together. Anonymity and intolerance were the trademarks of the state's dealings with the Fortescues. William Faithful Fortescue was just another name. Worse, it was the name of someone who had committed the ultimate Ascendancy taboo: a Protestant gentleman who had married a Catholic woman. Dublin Castle would have gladly turned their backs completely on Fortescue's memory but for the intervention of his comrades from the 27th. The cohesion that held the Inniskillings together at Waterloo continued to serve, saving the family of a fallen comrade. But as the years wore on there were fewer and fewer Inniskillings to keep that bond alive, and in time their cohesion and the memory of their service and sacrifice faded. They deserve better. 


\section{REFERENCES}

\section{Government Records}

National Archives, Kew, U.K.:

United Kingdom War Office. 1/27th Casualty Returns, 1815. WO 25/1671

ibid., $1 / 27^{\text {th }}$ Regimental rosters, $1815-1816$. WO $12 / 4344$

ibid., $27^{\text {th }}$ Foot Regimental Recruit Rosters. WO 97/340/16

ibid., Description Book, $27^{\text {th }}$ Foot. WO 25/356

ibid., Chelsea Hospital Prize Money Disbursements, 1816. WO 164/626

ibid., Waterloo Prize Money Disbursements. WO 164/403

ibid., Pension submission, Lt. William Faithful Fortescue. WO 43/129

ibid., British Army Lists. Military Records Information 17

\section{$\underline{\text { Regimental Records }}$}

Regimental Records, Inniskilling Regimental Museum, Enniskillen, Northern Ireland.

Census Records:

Clarkson, L.A. et al., Database of Irish Historical Statistics : Language, 1851-1911 [computer file]. Colchester, Essex: UK Data Archive [distributor], November 1997. SN: 3573. http://www.data-archive.ac.uk/

ibid., Literacy: 1841-1911, SN: 3582

ibid., Religion, 1861-1911, SN 3579 
ibid., Housing, 1821-1911, SN 3583

\section{$\underline{\text { Books }}$}

Adkin, Mark, The Waterloo Companion (Mechanicsburg, PA.: Stackpole Books, 2001)

Anonymous, Personal Narrative of a Private Soldier Who Served in the Forty-Second Highlanders for Twelve Years, during the late War (London: Ken Trotman, 1996)

Anonymous, The Little Bombardier and Pocket Gunner (London: T. Egerton, 1801)

Ardrey, Robert, The Territorial Imperative (New York: Collins, 1967)

Barnett, Correlli, Britain and Her Army, 1509-1970: A Military, Political, and Social Survey (New York, William Morrow \& Company, 1970)

Best, Geoffrey, War and Society in Revolutionary Europe (New York: St. Martin's Press, 1982)

Blackstock, Allan, An Ascendancy Army: The Irish Yeomanry, 1796-1834 (Dublin: Four Courts Press, 1998)

Bowden, Scott, Armies at Waterloo (Arlington, TX.: Empire Press, 1983) , Armies on the Danube, 1809 (Arlington, TX: Empire Press, 1980)

Brett-James, Anthony, The Hundred Days (New York: St. Martin’s Press, 1964) , Wellington at War, 1794-1815 (London: Macmillan \& Company, 1961)

Brewer, John, The Sinews of Power (New York: Alfred A. Knopf, 1989)

Brotherton, Captain Thomas, A Hawk at War, Bryan Perrett, ed. (Cippenham: Picton Publishing, 1986)

Buckley, Roger Norman, The British Army in the West Indies: Society and the Military in the Revolutionary Age (Gainesville: University Press of Florida, 1998) 
Carew, Tim, How the Regiments got their Nicknames (London: Leo Cooper, 1974)

Cassidy, Martin, Marching with Wellington (Barnsley, Yorkshire: Leo Cooper, 2003)

Chalfont, Lord Arthur, ed., Waterloo: Battle of Three Armies (New York: Alfred A. Knopf, 1979)

Chandler, David, The Campaigns of Napoleon (New York: MacMillan Publishing, 1966) , On the Napoleonic Wars (London: Greenhill Books, 1999)

Cole, General Sir Lowery Cole, Memoirs of Sir Lowery Cole (London: Macmillan and Co. Limited, 1934)

Corvisier, André, L'Armée Française de la fin du XVII siècle au ministère de Choiseul: Le Soldat (Paris: Presses Universitaires de France: 1964)

Crowley, Tony, Wars of Words : The Politics of Language in Ireland 1537-2004 (Oxford : Oxford University Press, 2005)

Dalrymple, Henry, Tacticks (Dublin: George Bonham, 1782)

Dalton, Charles, The Waterloo Roll Call (New York: Hippocrene Books, 1971)

Davis, Robert, The War of the Fists: Popular Culture and Public Violence in Late Renaissance Venice (Oxford: Oxford University Press, 1994)

de Paor, Liam, The Peoples of Ireland, (Notre Dame: University of Notre Dame Press, 1986)

Duffy, Seán, The Concise History of Ireland (Derbyshire: Arcadia Editions Limited, 2000)

Elliott, Marianne, Partners in Revolution: The United Irishmen and France (New Haven: Yale University Press, 1982)

Elting, Colonel John, Swords Around a Throne (New York: The Free Press, 1988)

Ehrenreich, Barbara, Blood Rites (New York: Metropolitan Books, 1997)

Fitchett, William, ed., Wellington's Men: Some Soldier Autobiographies (London: George Bell \& Sons, 1900)

Frey, Sylvia, The British Soldier in America: A Social History of the Military Life in the Revolutionary Period (Austin: University of Texas Press, 1981) 
Fromm, Erich, The Anatomy of Human Destructiveness (New York: Holt, Rinehart and Winston, 1973)

Glover, Gareth, Letters from the Battle of Waterloo (London: Greenhill Books, 2004)

Glover, Richard, Peninsular Preparation: the Reform of the British Army, 1795-1809

(Cambridge: Cambridge University Press, 1963)

Goldsworthy, Adrian Keith, The Roman Army at War, 100 BC - AD 200 (Oxford:

Clarendon Press, 1996)

Grattan, William, Adventures with the Connaught Rangers 1809-1814 (London:

Greenhill Books, 1989)

Great Britain, Army, Regulation for Improving the Situation of Regimental Surgeons and Mates (London: War Office, 1796)

, Rules and Regulations for the formations, field-exercise, and movements, of His Majesty's forces (London: War Office, 1792)

Gregory, Lady Augusta, Irish Myths and Legends (Philadelphia: Running Press, 1998) originally published as Gods and Fighting Men (London: John Murray, 1910)

Grossman, Lt. Colonel Dave, On Killing (Boston: Back Bay Books, 1995)

Hanson, Victor Davis, The Western Way of War (Oxford: Oxford University Press, 1989)

Harris, Rifleman Benjamin Harris, Recollections of Rifleman Harris (Hamden, CT: Archon, 1970)

Haythornthwaite, Phillip, The Armies of Wellington (London: Arms and Armour Press, 1994)

Henderson, Diana M., Highland Soldier: A Social Study of the Highland Regiments, 1820-1920 (Edinburgh: John Donald Publishers Ltd., 1989)

Hofschröer, Peter, 1815: The Waterloo Campaign (London: Greenhill Books, 1999) , The Hanoverian Army of the Napoleonic Wars (London: Osprey, 1989)

Holmes, Richard, Acts of War: The Behavior of Men in Battle (New York: The Free Press, 1985)

, Redcoat: The British Soldier in the Age of Horse and Musket (London:

Harper Collins Publishers, 2001) 
Houlding, J. A., Fit for Service: The Training of the British Army, 1715-1795 (Oxford: Clarendon Press, 1981)

Howarth, David, Waterloo: A Near Run Thing (Gloucestershire: The Windrush Press, 1968)

Huff, Julius, Violence in Modern Europe 1500-1800 (Cambridge: Cambridge University Press, 2001)

James, Charles, The Regimental Companion, Volumes I and II (London: T. Egerton, 1800)

Jeffrey, George, Tactics and Grand Tactics of the Napoleonic Wars (Brockton, MA: The Courier Publishing Company, 1982)

Karsten, Peter, ed., Motivating Soldiers: Morale or Mutiny (New York: Garland Publishing, Inc., 1998)

Keegan, John, The Illustrated Face of Battle (New York, Viking Penguin Inc., 1989) , The Book of War (New York, Viking Penguin Inc., 1999) , The Mask of Command (New York, Viking Penguin Inc., 1987)

Kellett, Anthony, Combat Motivation: The Behavior of Soldiers in Battle (Boston: Kluwer, 1982)

Kincaid, Captain John, Adventures in the Rifle Brigade (Glasgow: Richard Drew, 1981)

Kindsvatter, Peter, American Soldiers: Ground Combat in the World Wars, Korea, and Vietnam (Lawrence: University of Kansas Press, 2003)

Lawrence, Sergeant William, The Autobiography of Sergeant William Lawrence (London: Sampson, Low, Marston, Saerle \& Rivington, 1886)

Lee, Wayne E., Crowds and Soldiers in Revolutionary North Carolina (Gainesville: University Press of Florida, 2001)

Leeke, Ensign William, The History of Lord Seaton's Regiment at the Battle of Waterloo (London: Hatchard, 1866)

Linderman, Gerald, Embattled Courage: The Experience of Combat in the American Civil War (New York: The Free Press, 1987)

Longford, Elizabeth, Wellington: Pillar of State (New York: Harper and Row, Publishers, 1972) 
Lynn, John A., The Bayonets of the Republic (Boulder, CO.: Westview Press, 1984)

MacBride, MacKenzie, ed., With Napoleon at Waterloo (Philadelphia: J.B. Lippincott Company, 1911)

Mann, Michael, And On They Rode: The King's Dragoon Guards at Waterloo (Salisbury: Southern Press, 1984)

Marshall, S. L. A., Men against Fire (Norman: University of Oklahoma Press, 1947)

McNeill, William H., The Pursuit of Power (Chicago: University of Chicago Press, 1982)

McPherson, James, For Cause and Comrades: Why Men Fought in the Civil War (Oxford: Oxford University Press, 1997)

Mercer, Cavalié, Journal of the Waterloo Campaign (New York: Da Capo Press, 1995)

Mitchell, B.R., Abstract of British Historical Statistics (Cambridge: Cambridge University Press, 1961)

Morris, Sergeant Thomas, Recollections (London: Bells, 1845)

Muir, Rory, Tactics and the Experience of Battle in the Age of Napoleon (New Haven, CT.: Yale University Press, 1998)

Napier, Captain George, Passages in the Early Military Life of General Sir George T. Napier (London: John Murray, 1884)

Nosworthy, Brent, With Musket, Cannon, and Sword: Battle Tactics of Napoleon and His Enemies (New York: Sarpedon, 1996)

O'Callagahan, Liam, The Irish in the English Army (Dublin: Butler Press, 1843)

Ó Dónaill, Éamonn, Irish On Your Own (Chicago: Passport Books, 1997)

Packenham, Thomas, The Year of Liberty (Englewood Cliffs, N.J.: Prentice-Hall, 1969)

Park, S. J., and Nafziger, George, The British Military: System and Organization, 18031815 (Cambridge, Ontario: Rafm Company, 1983)

Pope, Dudley, The Black Ship (New York: Henry Holt \& Company, 1963)

Regimental Historical Records Committee, The Royal Inniskilling Fusiliers from December 1688 to July 1914 (London: Constable and Company Ltd., 1934) 
Rogers, Colonel H. C. B., The British Army of the Eighteenth Century (London: George Allen \& Unwin Ltd., 1977)

Rothenberg, Gunther, The Art of Warfare in the Age of Napoleon (Bloomington:

University of Indiana Press, 1978)

Ruff, Julius, Violence in Early Modern Europe (Cambridge: Cambridge University Press, 2001)

Siborne, Captain William, History of the War in France and Belgium in 1815 (London: T. and W. Boone, 1848) , Waterloo Letters (London: Greenhill Books, 1993) first published as Waterloo Letters (London: Cassell, 1891)

Sikora, Michael, Disziplin und Desertion; Strukturprobleme militärischer Organisation in 18. Jahrhundert (Berlin: Dunker \& Humbolt, 1996)

Skelley, Alan Ramsey, The Victorian Army at Home; The Recruitment and Terms and Conditions of the British Regular, 1859-1899 (London: Croom Helm, 1977)

Smith, Digby, Napoleon's Regiments (London: Greenhill Press, 2000)

Stock, Archbishop Joseph, A Narrative of What Passed at Killala During the French Invasion of 1798 (Dublin: DuFour Editions, 1982)

Trustram, Myna, Women of the Regiment; Marriage and the Victorian Army (Cambridge: Cambridge University Press, 1984)

Von Pivka, Otto, Armies of the Napoleonic Era (New York: Taplinger Publishing Company, 1979)

Wagner, Heinrich, Linguistic Atlas and Survey of Irish Dialects (Dublin: Dublin Institute for Advanced Studies, 1958)

Ward, S.G.P., Wellington’s Headquarters (Oxford: Oxford University Press, 1957)

Wason, David, Battlefield Detectives (London: Grenada, 2003)

Wheeler, Private William, The Letters of Private Wheeler, Captain B. H. Liddell Hart, ed., (Boston: Houghton Mifflin Press, 1951)

Wise, Terence, Flags of the Napoleonic Wars (II) (London: Osprey Publishing, 1978)

Articles, Dissertations, etc. 
Chambers, John Whiteclay, “Conference Review Essay: The New Military History: Myth and Reality” The Journal of Military History, Vol. 55, No. 3 (Jul., 1991), 395-406.

Crowe, Lieutenant Charles, Memoirs (unpublished manuscript, Inniskilling Regimental Museum, Enniskillen, Northern Ireland)

Ellis, John Duncan, "Recruitment and Promotion in the Napoleonic British Army: A Study of the $28^{\text {th }}$ (North Gloucestershire) Regiment of Foot, an English Regiment at Waterloo" (BA (Honors) dissertation., Cheltenham and Gloucester College, 1999)

Frey, Sylvia, "Courts and Cats: British Military Justice in the $18^{\text {th }}$ Century" Military Affairs, 43 (1979) 5-11.

Garnham, Neal, "How Violent was Eighteenth-century Ireland?" Irish Historical Studies, xxx. No. 119 (May 1997), 377-392.

Grimsley, Mark, "In Not So Dubious Battle: The Motivations of American Civil War Soldiers" The Journal of Military History, Vol. 62, No. 1 (Jan. 1998) 175-188.

Haly, Captain Aylmer, "A Letter to Colonel Brownwigg” in The British Military Library or Journal, vol II., (London: British Military Library, 1800) 8-11.

Hates-McCoy, G.A., "Insurgent efforts towards military organization, 1798" The Irish Sword, Volume III, no. 12, 1958, 153.

Hendrix, Scott, "The Spirit of the Corps: The British Army and the Pre-National PanEuropean Military World and the Origins of American Martial Culture, 1754-1783" PhD. Dissertation, Ohio State University, 2005.

Howard, Michael, "Wellington and the British Army", in Studies in War and Peace (New York: Viking, 1970)

Kavanagh, James, Daniel Schnurr, and Paul Hill, "Wellington etait-il geometre? RTH GPS revele Waterloo" paper presented at Best Practice in Positioning, FIG Working Week, Paris, France, April 13-17, 2003.

Lynn, John, "The Embattled Future of Academic Military History" The Journal of Military History Vol. 61, No. 4 (Oct. 1997) 777-789.

Macready, Ensign Edward, “On a Part of Captain Siborne's History of the Waterloo Campaign”, Colburn’s United Service Magazine, 1845, Part I.

Sprig of Shillelagh, the monthly journal of the $27^{\text {th }}$ Foot, June 1891 to June 1896 , Inniskilling Regimental Museum, Enniskillen, Northern Ireland. 